Prepared in cooperation with the U.S. Department of Agriculture Forest Service and the Colorado Division of Reclamation, Mining and Safety

\title{
Quantification of Metal Loading Using Tracer Dilution and Instantaneous Synoptic Sampling and Importance of Diel Cycling in Leavenworth Creek, Clear Creek County, Colorado, 2012
}

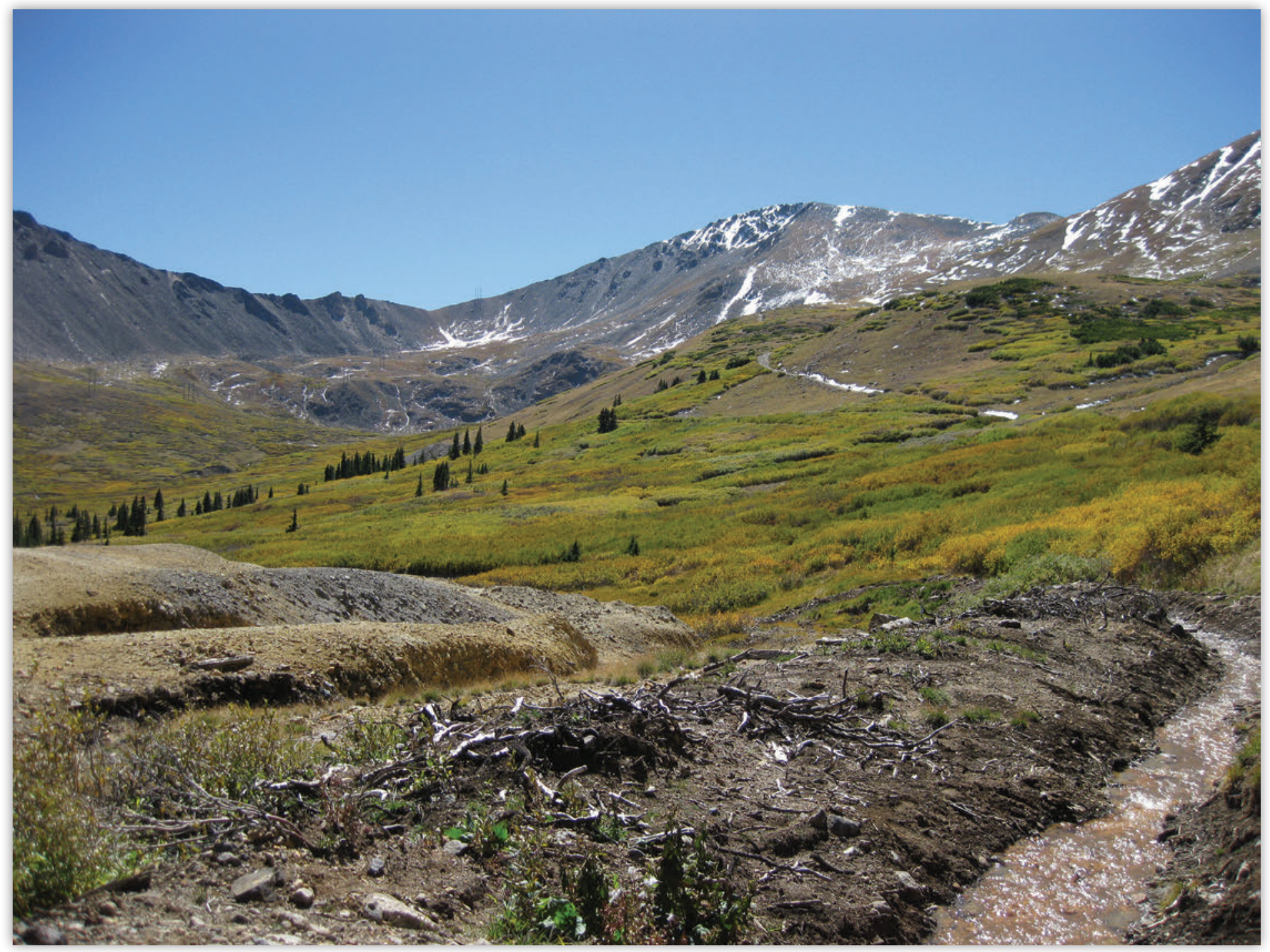

Open-File Report 2021-1078

U.S. Department of the Interior U.S. Geological Survey 
Cover. View upstream from Wilcox Tunnel showing Wilcox Tunnel drainage and mine waste associated with the Waldorf Mine site to the left. Argentine Peak (13,738 feet) is in the background. Photograph by Katherine Walton-Day, U.S. Geological Survey, September 26, 2013. 


\section{Quantification of Metal Loading Using Tracer Dilution and Instantaneous Synoptic Sampling and Importance of Diel Cycling in Leavenworth Creek, Clear Creek County, Colorado, 2012}

By Katherine Walton-Day, Robert L. Runkel, Christin D. Smith, and Briant A. Kimball

Prepared in cooperation with the U.S. Department of Agriculture Forest Service and the Colorado Division of Reclamation, Mining and Safety

Open-File Report 2021-1078 


\section{U.S. Geological Survey, Reston, Virginia: 2021}

For more information on the USGS — the Federal source for science about the Earth, its natural and living resources, natural hazards, and the environment—visit https://www.usgs.gov or call 1-888-ASK-USGS.

For an overview of USGS information products, including maps, imagery, and publications, visit https://store.usgs.gov/.

Any use of trade, firm, or product names is for descriptive purposes only and does not imply endorsement by the U.S. Government.

Although this information product, for the most part, is in the public domain, it also may contain copyrighted materials as noted in the text. Permission to reproduce copyrighted items must be secured from the copyright owner.

\section{Suggested citation:}

Walton-Day, K., Runkel, R.L., Smith, C.D., and Kimball, B.A., 2021, Quantification of metal loading using tracer dilution and instantaneous synoptic sampling and importance of diel cycling in Leavenworth Creek, Clear Creek County, Colorado, 2012: U.S. Geological Survey Open-File Report 2021-1078, 37 p., https://doi.org/10.3133/ofr20211078.

Associated data for this publication:

Walton-Day, K., Runkel, R.L., and Kimball, B.A., 2021, Stream discharge, sodium, bromide, and specific conductance data for stream and hyporheic zone samples affected by injection of sodium bromide tracer, Leavenworth Creek, Clear Creek County, Colorado, August 2012: U.S. Geological Survey data release, https://doi.org/10.5066/P9HGC2V4.

ISSN 2331-1258 (online) 


\section{Acknowledgments}

The authors thank the U.S. Department of Agriculture Forest Service (Forest Service) and Colorado Division of Reclamation, Mining and Safety for supporting this project and contributing to field work. Thanks to numerous volunteers and retirees from the Forest Service and U.S. Environmental Protection Agency who contributed to sampling efforts, particularly on August 30, 2012. Thanks for field help are extended to Thomas Chapin, David Fey, Matt Nicotra, David Nimick, Aaron Pietruszka, Ted Struzeski, Philip Verplanck, Richard Wanty, and Ruth Wolf of the U.S. Geological Survey; Trez Skillern, Maribeth Pecotte, Catherine "Cookie" McLaughlin, Nick Edington, and Brian Lloyd (retired) of the Forest Service; Julie Annear and Al Amundson of the Colorado Division of Reclamation, Mining and Safety; Skip Feeney and Emily Everett of the Colorado Department of Public Health and Environment; Katherine Slape and Drew Christ of the URS Corporation; and Patrizia Onnis of the University of Cagliari. 



\section{Contents}

Acknowledgments ……...................................................................................................................

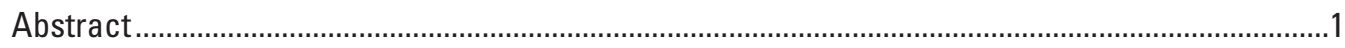

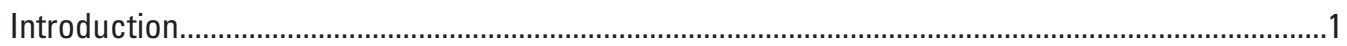

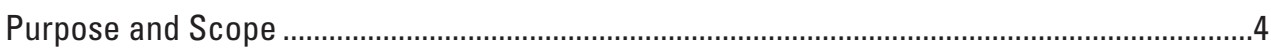

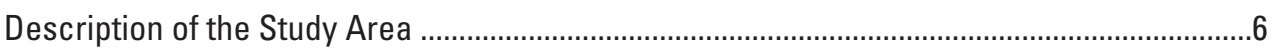

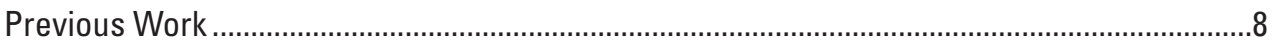

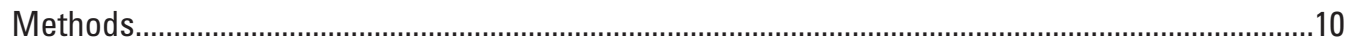

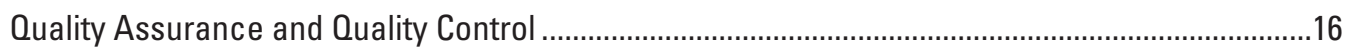

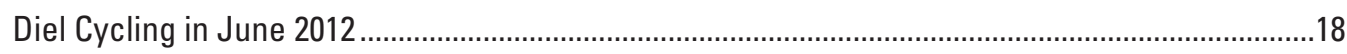

Diel Cycling, Tracer Dilution, Instantaneous Synoptic Sampling, and Metal Loading,

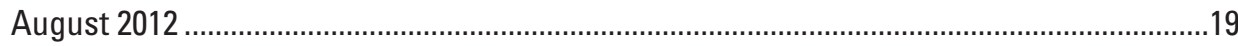

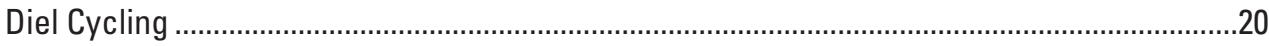

Tracer Dilution Stream Discharge Calculations ……………..............................................23

Instantaneous Synoptic Sampling and Stream Profiles of Water Quality................................26

Metal-Mass Loading Stream Profiles ................................................................................28

Effects of Vidler Tunnel Discharge on Water Quality in Leavenworth Creek ..................................30

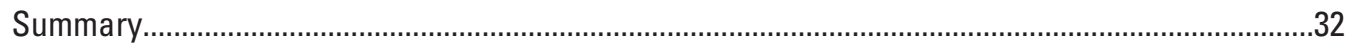

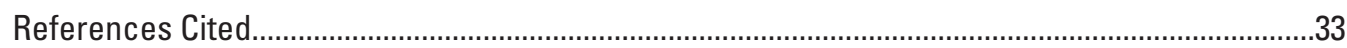

\section{Figures}

1. Schematic representation of a small watershed showing locations of mine drainage, subwatersheds in different colors $(A, B, C$, and D) defined by adjacent stream-sampling locations, locations of mine drainage or inflow-sampling site locations, and an outlet sampling location ........

2. Graphs showing diel variation in flow (stream discharge); manganese, zinc, and arsenic concentrations; and temperature and $\mathrm{pH}$

3. Map showing location of Leavenworth Creek, Colorado; the detailed study reach; U.S. Geological Survey streamgage at the mouth of Leavenworth Creek; the locations of the Wilcox Tunnel, Waldorf Mine, and Vidler Tunnel; and location of a site where limited continuous monitoring was conducted June 20-22, 2012, to investigate diel water-quality characteristics (LV2)

4. Map showing sites where water-quality samples were collected during synoptic sampling August 28-30, 2012, and a site (LV1) where diel samples were collected June 20-22, 2012

5. Photograph looking north along the study reach downstream from the Vidler Tunnel showing barren, unvegetated areas of dispersed tailings; approximate locations where most of the discharge from the Wilcox Tunnel and Waldorf seeps enters the stream; and where a left-bank inflow enters farther downstream .......8

6. Graph showing stream discharge hydrograph at U.S. Geological Survey station 06714800 in Colorado during March-December 2012

7. Graphs illustrating variation in temperature, dissolved oxygen, and $\mathrm{pH}$ at sites LV1 and LV2; and stream discharge at U.S. Geological Survey station 06714800, Leavenworth Creek, Colorado, June 20-22, 2012.. 
8. Graph showing fluctuation in zinc concentrations in filtered, acidified samples collected using automatic sampling devices at sites LV1 and LV2 in Leavenworth Creek, Colorado, June 20-22, 2012.

9. Graphs showing variation of temperature, $\mathrm{pH}$, and specific conductance at LC1137-S, T2, (T2), LC2023-S, T3 (T3), and LC1203-L; stream discharge at U.S. Geological Survey station 06714800; and dissolved oxygen at T3, during August 27-30, 2012

10. Graphs showing variation in filtered calcium, uranium, and zinc concentrations at LC1137-S, T2 and LC2023-S, T3; and stream discharge at U.S. Geological Survey station 06714800, Leavenworth Creek, Colorado, at the mouth near Georgetown, from August 28-30, 2012.

11. Graphs showing variation in bromide $(\mathrm{Br})$ concentrations measured and $\mathrm{Br}$ concentrations used to calculate stream discharge in all stream samples collected along Leavenworth Creek, Colorado, on August 30, 2012; and stream discharge calculated from $\mathrm{Br}$ concentrations and measured using velocity meters.....26

12. Graph showing stream profile of $\mathrm{pH}$ values measured in samples from the stream, left- and right-bank inflows, hyporheic sniffers, Vidler and Wilcox Tunnels, and Waldorf seeps

13. Graph showing stream profile of specific conductance measured in samples from the stream, left- and right-bank inflows, hyporheic sniffers, Vidler and Wilcox Tunnels, and Waldorf seeps.

14. Graph showing stream profile of filtered zinc concentrations in samples from the stream, left- and right-bank inflows, hyporheic sniffers, Vidler and Wilcox Tunnels, and Waldorf seeps

15. Graph showing stream profile of filtered copper concentrations in samples from the stream, left- and right-bank inflows, hyporheic sniffers, Vidler and Wilcox Tunnels, and Waldorf seeps

16. Graph showing stream profile of zinc concentrations in samples from the stream, left- and right-bank inflows, hyporheic sniffers, Vidler and Wilcox Tunnels, and Waldorf seeps from figure 14 and zinc load for the filtered stream samples

17. Graphs showing stream profiles of total (unfiltered) copper and lead loads and total (unfiltered) manganese and zinc loads in stream samples collected in Leavenworth Creek, Colorado, August 30, 2012

18. Graph showing proportional load with downstream distance for copper, lead, manganese, and zinc in stream samples collected in Leavenworth Creek, Colorado, August 30, 2012

19. Photographs showing discharge from the Vidler Tunnel containing only native flow on August 29, 2012; discharge from the Vidler Tunnel containing native and imported flow on June 20, 2012; site LC689-L where discharge from the Vidler Tunnel joins Leavenworth Creek on August 29, 2012; and site LC689-L on August 27, 2008. 


\section{Tables}

1. U.S. Geological Survey station identification numbers, site identification descriptions, and field identification numbers

2. Schedule and description of field work in Leavenworth Creek, Colorado, June-August 2012

3. Constituents and reporting levels included in water-quality analysis of samples collected at Leavenworth Creek, Colorado, June and August 2012.

4. Summary of variability and bias evaluation of U.S. Geological Survey standard reference samples and laboratory and analytical replicate samples, Leavenworth Creek, Colorado, June and August 2012.

5. Comparison of total (unfiltered) and filtered concentrations and loads of copper, lead, manganese, and zinc measured in samples collected the Vidler Tunnel outflow in June and August 2012

\section{Conversion Factors}

U.S. customary units to International System of Units

\begin{tabular}{lll}
\hline \multicolumn{1}{c}{ Multiply } & By & \multicolumn{1}{c}{ To obtain } \\
\hline inch (in.) & Length & \\
foot (ft) & 2.54 & centimeter $(\mathrm{cm})$ \\
mile (mi) & 0.3048 & meter $(\mathrm{m})$ \\
& 1.609 & kilometer $(\mathrm{km})$ \\
\hline cubic foot per second $\left(\mathrm{ft}^{3} / \mathrm{s}\right)$ & Flow rate & \\
\hline
\end{tabular}

International System of Units to U.S. customary units

\begin{tabular}{lcl}
\hline & Multiply & \\
\hline & Length & \\
\hline centimeter (cm) & 0.3937 & inch (in.) \\
meter (m) & 3.281 & foot (ft) \\
kilometer (km) & 0.6214 & mile (mi) \\
\hline liter (L) & Volume & \\
\hline & 0.2642 & gallon (gal) \\
cubic meter per second (m3/s) & Flow rate & \\
liter per second (L/s) & 35.31 & cubic foot per second (ft3/s) \\
\hline & 15.85 & gallon per minute (gal/min) \\
\hline gram (g) & Mass & \\
kilogram (kg) & 0.03527 & ounce, avoirdupois (oz) \\
\hline
\end{tabular}

Temperature in degrees Celsius $\left({ }^{\circ} \mathrm{C}\right)$ may be converted to degrees Fahrenheit $\left({ }^{\circ} \mathrm{F}\right)$ as

$$
{ }^{\circ} \mathrm{F}=\left(1.8 \times{ }^{\circ} \mathrm{C}\right)+32 \text {. }
$$

Temperature in degrees Fahrenheit $\left({ }^{\circ} \mathrm{F}\right)$ may be converted to degrees Celsius $\left({ }^{\circ} \mathrm{C}\right)$ as

$$
{ }^{\circ} \mathrm{C}=\left({ }^{\circ} \mathrm{F}-32\right) / 1.8 \text {. }
$$




\section{Datum}

Vertical coordinate information is referenced to the North American Vertical Datum of 1988 (NAVD 88).

Horizontal coordinate information is referenced to the North American Datum of 1983 (NAD 83) and World Geodetic System of 1984 (WGS 84).

Elevation, as used in this report, refers to distance above the vertical datum.

\section{Supplemental Information}

Specific conductance is given in microsiemens per centimeter at 25 degrees Celsius ( $\mu \mathrm{S} / \mathrm{cm}$ at $\left.25^{\circ} \mathrm{C}\right)$.

Concentrations of chemical constituents in water are given in either milligrams per liter (mg/L) or micrograms per liter ( $\mu \mathrm{g} / \mathrm{L})$.

\section{Abbreviations}

$\begin{array}{ll}\text { Forest Service } & \text { U.S. Department of Agriculture Forest Service } \\ \text { ICP-MS } & \text { inductively coupled plasma-mass spectrometry } \\ \text { ID } & \text { identification } \\ \text { MPV } & \text { most probable value } \\ \text { NWIS } & \text { National Water Information System } \\ \text { RSD } & \text { relative standard deviation } \\ \text { SRS } & \text { standard reference sample } \\ \text { USGS } & \text { U.S. Geological Survey }\end{array}$




\title{
Quantification of Metal Loading Using Tracer Dilution and Instantaneous Synoptic Sampling and Importance of Diel Cycling in Leavenworth Creek, Clear Creek County, Colorado, 2012
}

\author{
By Katherine Walton-Day, Robert L. Runkel, Christin D. Smith, and Briant A. Kimball
}

\section{Abstract}

Leavenworth Creek, a tributary of South Clear Creek and Clear Creek near Georgetown, Colorado, contains copper, lead, and zinc at concentrations close to or in excess of aquatic-life standards. In the summer of 2012, the U.S. Geological Survey, in cooperation with the U.S. Department of Agriculture Forest Service and the Colorado Division of Reclamation, Mining and Safety, conducted monitoring to (1) quantify the effects of diel cycling and perform synoptic sampling in a way to minimize those effects, (2) separate "point" or distinct single tributaries or sources of load from diffuse load sources along the study reach to aid remediation planning, and (3) quantify metal loading from transmountain diversion of water from Peru Creek through the Vidler Tunnel into Leavenworth Creek. The study included monitoring for diel cycles in June 2012 and diel and synoptic sampling in August 2012 along an approximately 2-kilometer stream reach. Synoptic samples were collected at 26 stream and 35 inflow, tributary, mine waste seep, and mine tunnel sites from August 28 to 30, 2012.

In June 2012, temperature, dissolved oxygen, and pH showed strong diel signals at two sites in Leavenworth Creek, with temperature and $\mathrm{pH}$ having minimum values near dawn and maximum values during the afternoon and dissolved oxygen having maximum values in the early morning and minimum values in late afternoon. Concentrations of zinc, cadmium, cobalt, manganese, and yttrium showed strong diel fluctuations at both sites with minimum concentrations during daytime and maximum concentrations during nighttime. Because of these diel cycles, all stream sites were sampled during synoptic sampling at 1200 hours on August 30, 2012. During synoptic sampling from August 28 to 30, 2012, zinc showed maximum concentrations at nighttime and minimum concentrations at midday and diel variation ranged from 26 to 33 percent.

Inflows from the Wilcox Tunnel and Waldorf seep area were the greatest source of zinc load to the stream (about 45 percent), and a left-bank inflow in the dispersed tailings area was the greatest source of lead (about 45 percent) and manganese (about 25 percent) loads to the stream, and a secondary source for zinc (about 40 percent). Copper load was almost equally divided (about 35 percent) between these two sources. Diffuse loading, likely from left-bank sources, was evident for copper, lead, manganese, and zinc in the stream reach from approximately 800 to 1,200 meters, and for copper, lead, and, to a lesser extent, manganese in the reach containing left-bank dispersed tailings (from approximately 1,300 to 1,800 meters). The load values reported herein are minimum estimates because the stream synoptic samples were collected at 1200 hours when positively charged elements, including copper, lead, manganese, and zinc, have minimum concentrations. Diel patterns measured for zinc during the synoptic sampling indicate maximum daily zinc loads were as much as 33 percent greater than those measured at 1200 hours on August 30, 2012.

Transmountain diversion of water through Vidler Tunnel negatively affects water quality in Leavenworth Creek as indicated by much greater metal loads and concentrations and a visually evident mixing zone where Vidler Tunnel water joins Leavenworth Creek when diversion is active compared to when it is not.

\section{Introduction}

Understanding locations and magnitudes of metal loading to streams assists remediation planning where legacy mine waste affects water quality (Kimball and others, 2002; Mayes and others, 2008; Walton-Day and others, 2012; Jarvis and others, 2019). In general, sources of metal loading may be either distinct or diffuse. Some examples of distinct sources are individual tributaries or draining mine adits. Examples of diffuse sources include stream reaches where metal-rich groundwater contributes metal loads or surficial deposits of mine waste contribute to poor water quality during storms or from persistent seepage. Distinct sources of metal loads, such as draining mine adits, and some diffuse sources, such as 
mine-waste piles, may be amenable to remediation. However, some diffuse sources, such as groundwater inputs to streams, may represent premining conditions or, if attributed to mining activity, may be difficult to remediate. Remediation planning is aided by understanding not only the magnitude and location of sources of metal loading but also whether sources are distinct or diffuse and amenable to known remediation strategies.

Tracer-dilution, synoptic-sampling studies provide massload profiles with stream distance that can be used to help locate and quantify all substantial sources of metal loading to a stream and distinguish distinct and diffuse sources (Nimick and Cleasby, 2001; Kimball and others, 2002, 2007; Kimball and Runkel, 2009; Walton-Day and others, 2012; Runkel and others, 2013). These studies use dilution of a salt tracer to provide a consistent downstream profile of stream discharge, which is multiplied by metal concentration to calculate instantaneous mass load. The spatial detail provided by this type of synoptic sampling gives a detailed profile of mass loading to the stream that identifies where metal loads from tributaries, other distinct sources, and diffuse sources (likely groundwater inflows) enter the stream (fig. 1; Kimball and Runkel, 2009). For example, in area B on figure 1, suppose the two streamsampling sites on the upstream and downstream end of this reach show no increase in metal load, despite a draining mine in area B. In contrast, in area D, there is a substantial increase in metal load between the two stream-sampling sites at the upstream and downstream ends of this reach. In this case, land managers might prioritize area D over area B for remediation or reclamation. Alternately, suppose the five stream-sampling sites and the outlet in area $\mathrm{C}$ show a progressive downstream increase in metal loads, but metal loads in the inflow sampling sites are less than the increase in instream metal loads. In this case, the mass-load profile provides evidence of additional metal load entering the stream from groundwater because metal load in surface water entering the stream is not sufficient to explain the instream load increases. This type of groundwater contribution to stream-metal load, if unrelated to mining or mining structures (tunnels) under the stream, might be difficult to remediate and might represent natural conditions. Land managers can use this information to guide location and choice of remedial activity to mitigate metal loads that adversely affect stream-water quality. As stated in Jarvis and others (2019, p. 702), "A quantitative understanding of the variable importance of point and diffuse sources of pollution, and instream processes of metal attenuation and release, is crucial to evaluating the benefits of treatment to downstream water quality." Several studies have demonstrated how massloading, tracer-dilution studies can support remedial decisions (Walton-Day and others, 2007, 2012; Kimball and Runkel, 2009; Kimball and others, 2010).

Diel cycling of metal (or trace-element) concentrations has been observed in many streams, particularly at near neutral and alkaline pH values (Fuller and Davis, 1989; Brick and Moore, 1996; Parker and others, 2007; Nimick and others, 2011; Gammons and others, 2015) with variations of up to approximately 1,000 percent recorded over a daily cycle for zinc (Balistrieri and others, 2012). Positively charged aqueous species (for example, zinc, copper, and cadmium) show maximum instream concentrations at minimum $\mathrm{pH}$ and temperature values just before dawn and minimum concentrations at maximum $\mathrm{pH}$ and temperature values midday to late day (fig. 2; Nimick and others, 2011). Conversely, negatively charged aqueous species, such as arsenic and molybdenum, have the opposite behavior, showing maximum instream concentrations at maximum $\mathrm{pH}$ and temperature values late in the day and minimum concentrations at minimum $\mathrm{pH}$ and temperature values just before dawn (fig. 2; Nimick and others, 2011).

The solar cycle causes instream cycles of photosynthesis, respiration of aquatic macrophytes, and changes in temperature and $\mathrm{pH}$ that cause adsorption and desorption of metals to inorganic and organic streambed material, resulting in diel cycles in metal concentrations (Fuller and Davis, 1989; Nimick and others, 2011; Gammons and others, 2015). Diel cycles complicate monitoring streams for compliance with water-quality standards and understanding spatial and temporal variations in metal concentrations and loads throughout a watershed, such as when conducting a mass-load study (Gammons and others, 2015). Stream concentrations change in time and space as a team walks a stream and collects samples during the course of a day, complicating interpretation of data. Gammons and others (2015) reported opposite loading patterns, depending on whether samples were collected from upstream to downstream or from downstream to upstream. One solution is to collect water-quality samples and monitor stream discharge every 1 or 2 hours over a 24-hour cycle at each stream site (Gammons and others, 2015). Loads are then calculated for each sample-collection time, averaged at each stream site to provide daily average load, and then compared among sites. Alternately, to save cost, samples collected over a 24-hour period could be composited into a single sample providing an average 24-hour concentration multiplied by daily average stream discharge at each site yielding a daily average load for each site (Gammons and others, 2015). Both approaches necessitate collection of samples and stream discharge over a 24-hour period, involving multiple people or automatic samplers at multiple sites, which is logistically and financially challenging. Limited resources might limit the number of sites, which in turn reduces spatial detail and could compromise the ability to identify important diffuse or distinct loading sources.

The solution selected for this study was to sample all stream sites at the same time using individuals stationed at each site. Each sample is associated with a stream discharge estimate calculated using the principles of tracer dilution and described in the "Methods" and "Tracer Dilution Stream Discharge Calculations" sections of this report. These data enable construction of instantaneous load profiles for the stream and comparison of metal loads from site to site along the stream reach to minimize the effects of diel variations in metal concentrations and stream discharge and still maximize spatial detail. This approach does not yield comparisons of daily average loads along the stream, as recommended by 


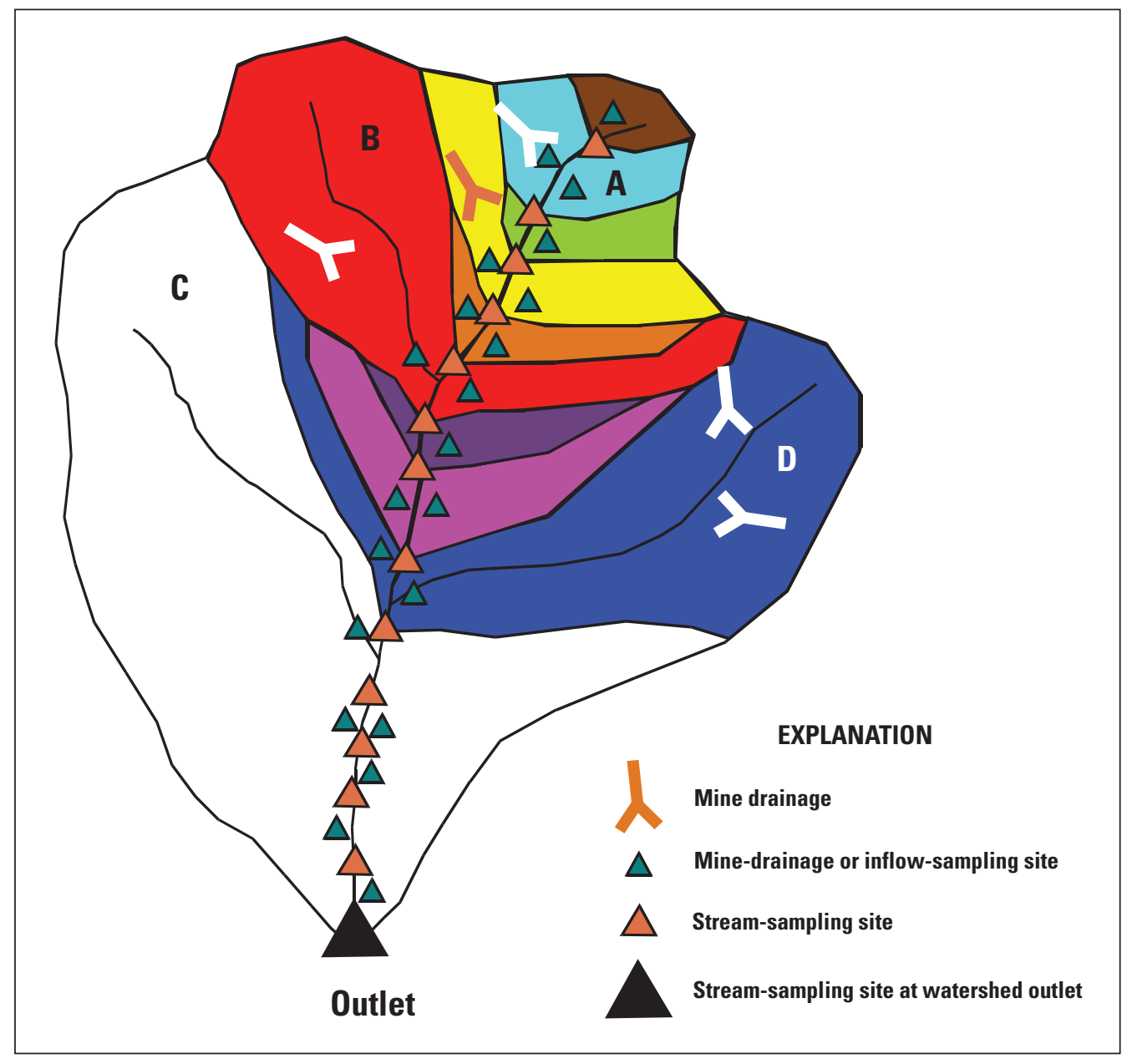

Figure 1. Schematic representation of a small watershed showing locations of mine drainage, subwatersheds in different colors (A, B, C, and D) defined by adjacent stream-sampling locations, locations of mine drainage or inflow-sampling site locations, and an outlet sampling location.

Gammons and others (2015), but rather comparison of loads at the time of sample collection. Data collected in this manner are only extrapolated with extreme caution to estimate load during time periods other than the time of sample collection. For example, mass-loads calculated from samples collected during the day, when positively charged metals have low concentrations, will likely underpredict daily mass loads.

Leavenworth Creek, a tributary of South Clear Creek and Clear Creek near Georgetown, Colorado, contains copper, lead, and zinc at concentrations close to or in excess of aquatic-life standards (U.S. Environmental Protection Agency, 2012). These elevated metal concentrations likely result from natural mineralization and historical mining operations in the Argentine mining district in the watershed. Previous research (data collected in 2002 and 2003) indicated that the primary sources of copper and zinc to Leavenworth Creek were the flowing Waldorf Mine adit (also known as the Wilcox Tunnel) and metals leached from associated mill-tailings waste located down valley from the mine (Fey and Wirt, 2007). This previous study reported that remediation that rerouted adit water away from a mine-waste pile had little effect on copper and zinc loads in the creek (Fey and Wirt, 2007) although the remediation seemed to diminish discharge from seeps (herein, Waldorf seeps) at the base of the Waldorf waste dump (McDougal and Wirt, 2007).

In 2012, the U.S. Department of Agriculture Forest Service (Forest Service) and Colorado Division of Reclamation, Mining and Safety requested the U.S. Geological Survey (USGS) to reassess sources of metal loading to Leavenworth Creek to assist remediation planning in light of changes that had occurred in the watershed since the previous study (Fey and Wirt, 2007), including increased discharge from the Vidler Tunnel (Story, 2009) and a blowout event (unconstrained release of mine-affected sediment and water from a mine adit likely caused by collapse of underground mine workings) at the Wilcox Tunnel. USGS expertise was sought to help better understand the role of diel cycles in metal-loading studies, and to conduct the metal-loading study using tracer-dilution to measure stream discharge, a technique in which USGS has extensive experience and expertise 

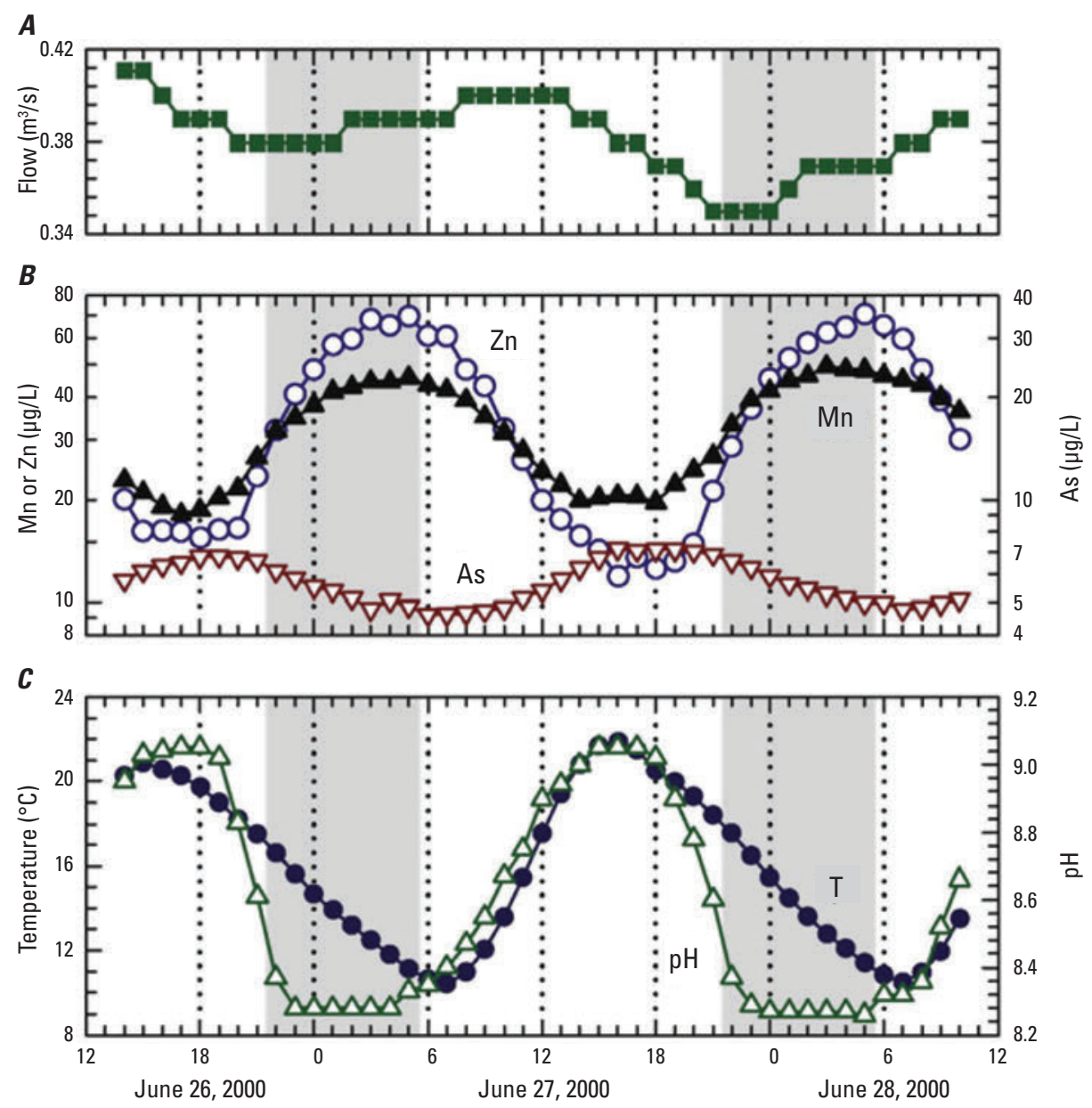

Figure 2. Graphs showing diel variation in $A$, flow (stream discharge), in cubic meters per second $\left(\mathrm{m}^{3} / \mathrm{s}\right) ; B$, manganese ( $\left.\mathrm{Mn}\right)$, zinc $(\mathrm{Zn})$, and arsenic (As) concentrations in micrograms per liter $(\mu \mathrm{g} / \mathrm{L})$; and $C$, temperature $(\mathrm{T})$ in degrees Celsius $\left({ }^{\circ} \mathrm{C}\right)$ and $\mathrm{pH}$ in standard units.

The $x$-axis represents date and hour of the day; shaded areas represent nighttime. Data is from Prickly Pear Creek, Montana. Reprinted with permission from Nimick and others (2011, fig. 2).

(Kimball and others, 1999, 2002, 2007, 2010; Kimball and Runkel, 2009; Walton-Day and others, 2012; Runkel and others, 2013).

Accordingly, in the summer of 2012, the USGS monitored diel cycles and conducted a mass-loading study to identify the location and magnitude of sources of copper, lead, manganese, and zinc to Leavenworth Creek along an approximately 2-kilometer $(\mathrm{km})$ reach extending from the headwaters upstream from the Vidler Tunnel inflow past the Wilcox Tunnel and Waldorf mine waste to downstream from dispersed mill tailings on the west side of the creek (figs. 3 and 4; table 1 provides USGS station identification [ID] numbers, site ID descriptions, and field ID numbers). The objectives of this study were to (1) quantify the effects of diel cycling and design synoptic sampling to minimize those effects, (2) separate "point" or distinct single tributary loads from diffuse load sources along the study reach to aid remediation planning, and (3) quantify metal loading from transmountain diversion of water from Peru Creek through the Vidler Tunnel into Leavenworth Creek. The study included monitoring for diel cycles in June 2012 and diel and synoptic sampling in August 2012. Synoptic samples at 26 stream and 35 inflow, tributary, mine waste seep, and mine tunnel sites were collected August 28-30, 2012. All stream samples were collected at the same time (within approximately 1 to 2 minutes of each other) at 1200 hours on August 30.

\section{Purpose and Scope}

The primary purpose of this report is to describe mass loading of selected constituents (copper, lead, manganese, and zinc) to locate and quantify sources of metal loads to Leavenworth Creek. Field work included sampling 61 sites from August 28 to 30, 2012, along a stream reach extending from the headwaters upstream from the Vidler Tunnel inflow, 


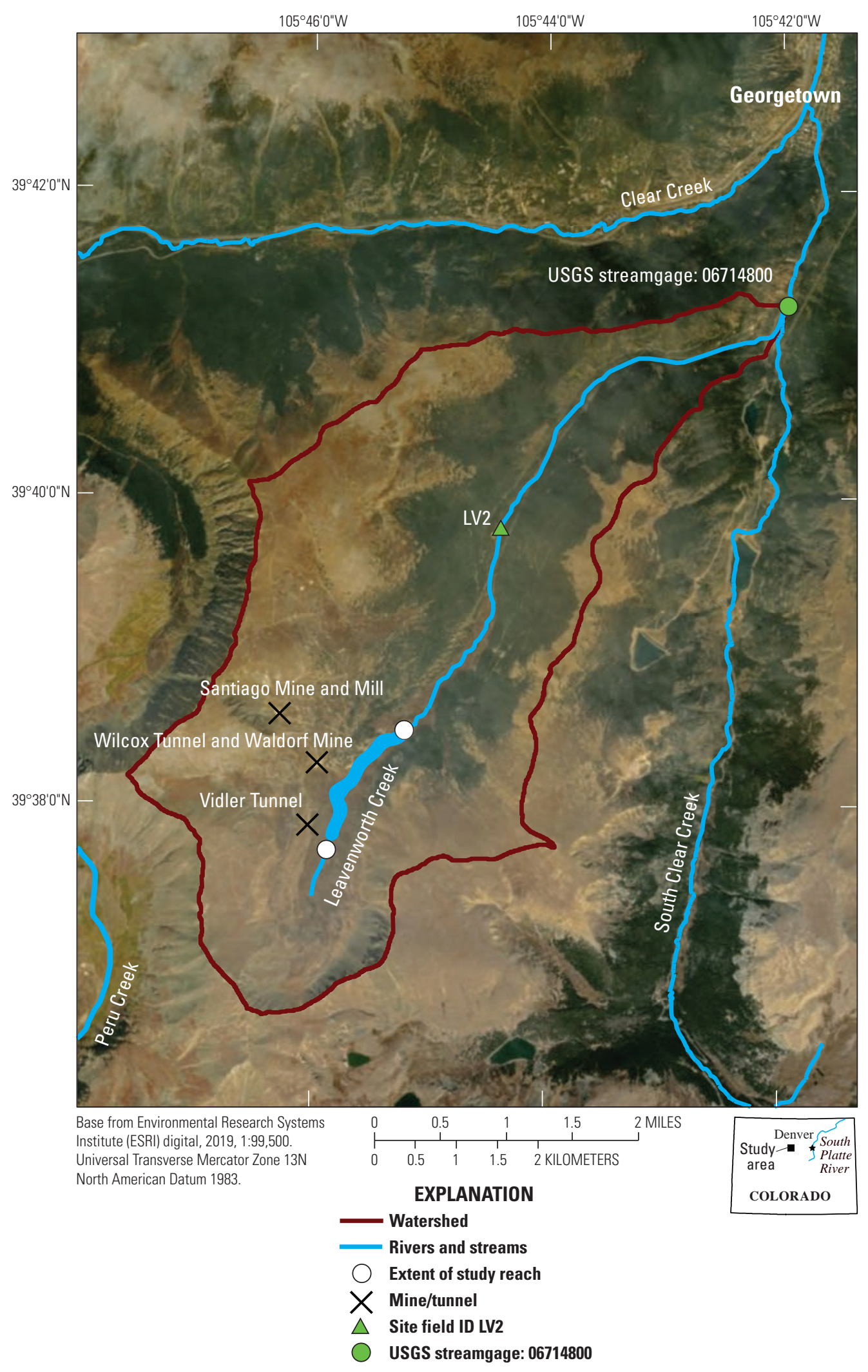

Figure 3. Map showing location of Leavenworth Creek, Colorado; the detailed study reach; U.S. Geological Survey (USGS) streamgage at the mouth of Leavenworth Creek; the locations of the Wilcox Tunnel, Waldorf Mine, and Vidler Tunnel; and location of a site where limited continuous monitoring was conducted June 20-22, 2012, to investigate diel water-quality characteristics (LV2). (USGS station identification [ID] numbers, site ID descriptions, and field ID numbers are in table 1.) 
past the Wilcox Tunnel and mine waste associated with the Waldorf Mine site, to downstream from dispersed mill tailings located on the west side of the creek (figs. 3 and 4). In addition, diel cycling was monitored to determine its magnitude in the stream and effects on metal concentrations. Finally, the study assessed the amount and effect of metal loading to the stream from the Vidler Tunnel using photographs, results of the August 28 to 30 synoptic sampling, and data from highflow synoptic sampling conducted by other entities.

Diel variation in water-quality properties (water temperature, $\mathrm{pH}$, specific conductance, and sometimes dissolved oxygen) and stream water quality were monitored using waterquality sondes and samples collected from Teledyne ISCO automatic samplers installed at two sites from June 20 to 22 and at three sites from August 27 to 30.

Synoptic samples were collected from August 28 to August 30 at 26 stream sites and at 35 additional sites that included direct inflows to the stream, mine tunnels, seeps from the bottom of a waste pile, tributaries, and the substream hyporheic zone (sniffer sites) (fig. 4). All synoptic samples were analyzed for major- and trace-element concentrations. Stream discharge was determined using dilution of an injected sodium bromide $(\mathrm{NaBr})$ tracer, velocity-meter measurements, volumetric measurement, and visual estimates where physical measurement was impractical and subject to large error. Longitudinal profiles (along stream distance) of concentrations and values in stream and inflow samples were constructed for $\mathrm{pH}$ and specific conductance and for filtered zinc and copper concentrations. Mass loads were estimated for the 26 stream sites as the product of metal concentrations and stream discharge for filtered zinc concentrations and for total (unfiltered) concentrations of copper, lead, manganese, and zinc.

\section{Description of the Study Area}

The study area is west of Denver, Colo., and southwest of Georgetown, Colo. The detailed study reach is near the headwaters of Leavenworth Creek and contains inflow from the Vidler Tunnel, Wilcox Tunnel, and Waldorf Mine area (fig. 3). Leavenworth Creek flows southwest to northeast from its headwaters to its confluence with South Clear Creek (just downstream from USGS streamgage 06714800) which then flows into Clear Creek (a tributary to the South Platte River) approximately 2 miles farther downstream within the town boundaries of Georgetown, Colo. (fig. 3).

The valley containing Leavenworth Creek in the study area is broad and glaciated (fig. 5), containing Quaternary glacial and alluvial sand and gravel overlying Precambrian rocks. Precambrian rocks consist primarily of early Proterozoic (specifically, Paleoproterozoic) biotite, granite, and quartz feldspar gneiss, which are approximately 1.7 billion years old (Kellogg and others, 2008), that are intruded by the mid-Proterozoic (specifically, the Mesoproterozoic) Silver Plume Granite of the Berthoud Plutonic Suite (referred to in this report's cited references as "Silver Plume Granite"), which is approximately
1.4 billion years old (Hedge, 1969; Kellogg and others, 2008). These basement rocks were intruded in a limited area of the valley by Eocene rhyolite porphyry (approximately 37 million years old; Kellogg and others, 2008). During the Pleistocene, the valley was glaciated and contains deposits from the most recent glaciation, the Pinedale (Kellogg and others, 2008). Other Quaternary deposits represented in the Leavenworth Creek valley include valley alluvium, a rock glacier in the southeast part of the valley, talus and landslide deposits, and colluvium (Kellogg and others, 2008). Elevations range from 2,829 meters (m; 9,280 feet) at USGS station 06714800 (USGS, 2019a) to 4,221 m (13,850 feet) at Mount Edwards along the west side of the valley (14ers.com, 2019).

Leavenworth Creek watershed is in the Front Range of Colorado and is characterized by climate typical to Colorado and the Rocky Mountains, including broad swings in temperature between daytime and nighttime, decreases in temperature and increases in precipitation with elevation, the majority of precipitation falling as snow during winter months, and the possibility of frequent afternoon southwest monsoonal thunderstorms during July and August (Doeskin and others, 2003). The Cabin Creek weather station (39.65528, -105.70889) (Colorado State University, 2019) is located approximately $5.3 \mathrm{~km}$ east-northeast of the Wilcox Tunnel at an elevation of approximately 3,054 m (10,020 feet). From 1968 through 2016, this weather station recorded average annual maximum air temperature (in July and August) of 9.1 degrees Celsius (48.4 degrees Fahrenheit), average annual minimum air temperature (in January and February) of -4 degrees Celsius (24.8 degrees Fahrenheit), average annual total precipitation of 50.2 centimeters $(\mathrm{cm})$ (19.76 inches), and average annual total snowfall of $344 \mathrm{~cm}$ (135.6 inches) (Western Regional Climate Center, 2016). These climate patterns drive the hydrograph at the USGS streamgage at the mouth of the creek, which shows the typical mountain snowmelt-supported shape with maximum stream discharge in May and June, followed by the falling limb of the hydrograph overprinted by summer monsoonal thunderstorms, and base-flow conditions from fall through early spring (fig. 6). This hydrograph is affected by transmountain import of streamflow through the Vidler Tunnel, generally in the spring and early summer, and export of water through an aqueduct located downstream from the study area to Green Lake, also located downstream from the study area and not shown on any maps herein (U.S. Forest Service, 2013b).

The Vidler Tunnel is a transmountain water conveyance tunnel, which is described in more detail in the "Previous Work" section. The Wilcox Tunnel is a draining, abandoned mine adit associated with the historical Waldorf Mine in the Argentine mining district and is described in more detail in the "Previous Work" section. 


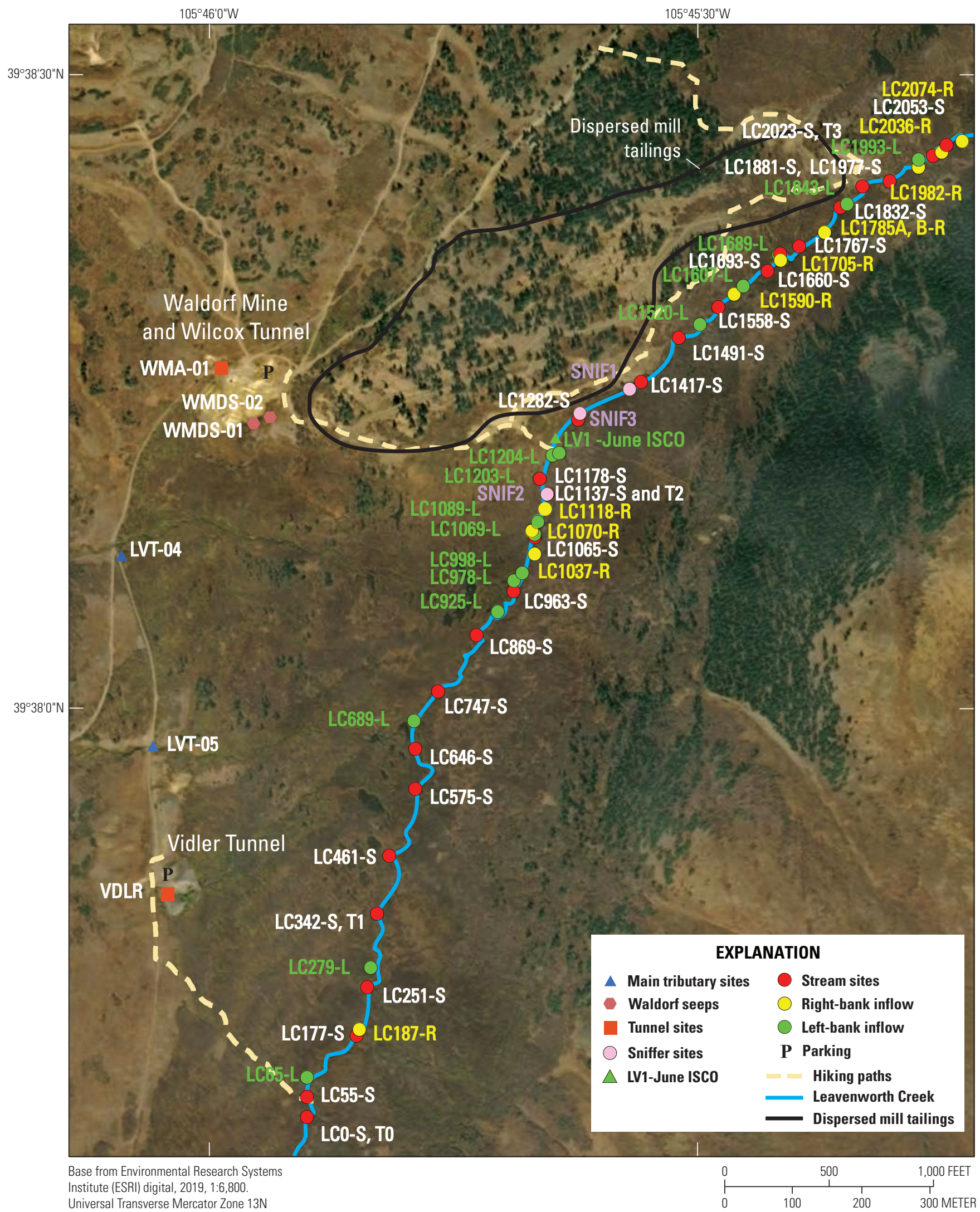

Figure 4. Map showing sites where water-quality samples were collected during synoptic sampling August 28-30, 2012, and a site (LV1) where diel samples were collected June 20-22, 2012. (U.S. Geological Survey station identification [ID] numbers, site ID descriptions, and field ID numbers are in table 1.) 


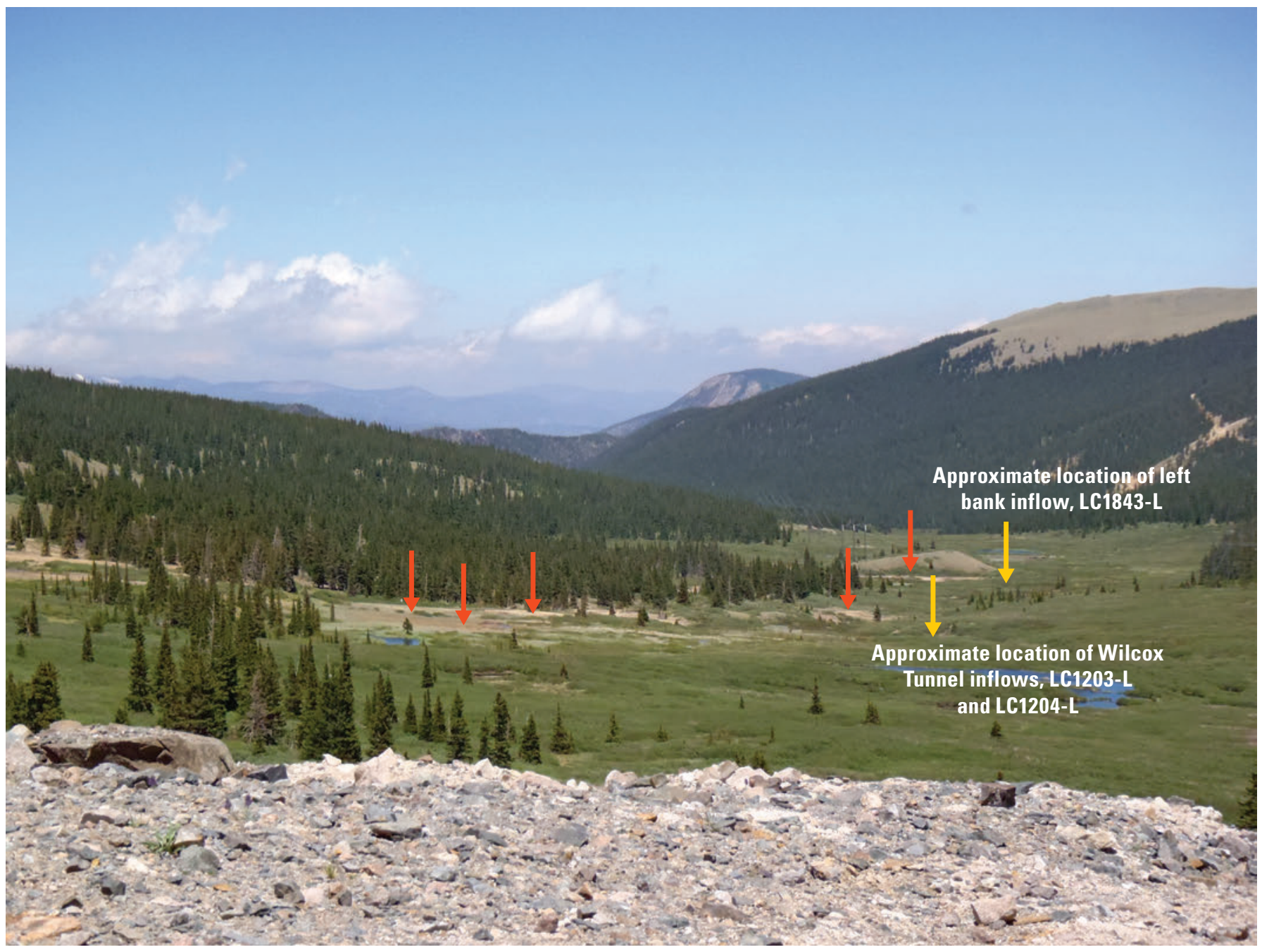

Figure 5. Photograph looking north along the study reach downstream from the Vidler Tunnel. Orange arrows indicate barren, unvegetated areas of dispersed tailings. Yellow arrows show approximate locations where most of the discharge from the Wilcox Tunnel and Waldorf seeps enters the stream and where a left-bank inflow enters farther downstream. Photograph by Katie Walton-Day, U.S. Geological Survey, June 20, 2012.

\section{Previous Work}

A compilation of previous environmental investigations in Leavenworth Creek and some of the surrounding area was completed for the Forest Service as part of a data gap analysis in 2013 (U.S. Forest Service, 2013b). Previous work described in this review and summarized herein includes descriptions of work completed at the Vidler Tunnel, at the Waldorf Mine and mill site and Wilcox Tunnel adit, at the Santiago Mine and mill site, and within the study reach in Leavenworth Creek.

The Vidler Tunnel is part of the water supply for Golden, Colo., and conveys transmountain water from Peru Creek in the headwaters of the Colorado River watershed into Leavenworth Creek, the headwaters of the South Platte River watershed (City of Golden, 2019; Colorado Division of Water Resources, 2019). The tunnel was originally intended to be a railroad tunnel, and construction began in 1901 (Lovering,
1935). The tunnel was completed in 1968, and first conveyed water in 1969 (U.S. Forest Service, 2013b). Some veins cut by the eastern half of the tunnel contain quartz and pyrite and lead-zinc ore (Lovering, 1935). Some ore was stoped in one vein, but no production figures were located by Lovering (1935), who concluded that "the property has never been an important producer” (p. 111). However, water interacting with veins containing pyrite in the tunnel has the potential to generate acid mine drainage. Discharge records starting in 1970 for a streamgage located at the east (Colorado River watershed) side of the tunnel are available at Colorado Division of Water Resources (2019). Previous water-quality investigations suggest some increases in metal concentrations in Leavenworth Creek where drainage from the Vidler Tunnel joins the creek (Story, 2009). High-flow sampling in June 2012 indicated that the Vidler Tunnel contained copper, lead, and zinc at greater than benchmark levels, and elevated zinc loads (U.S. Forest 


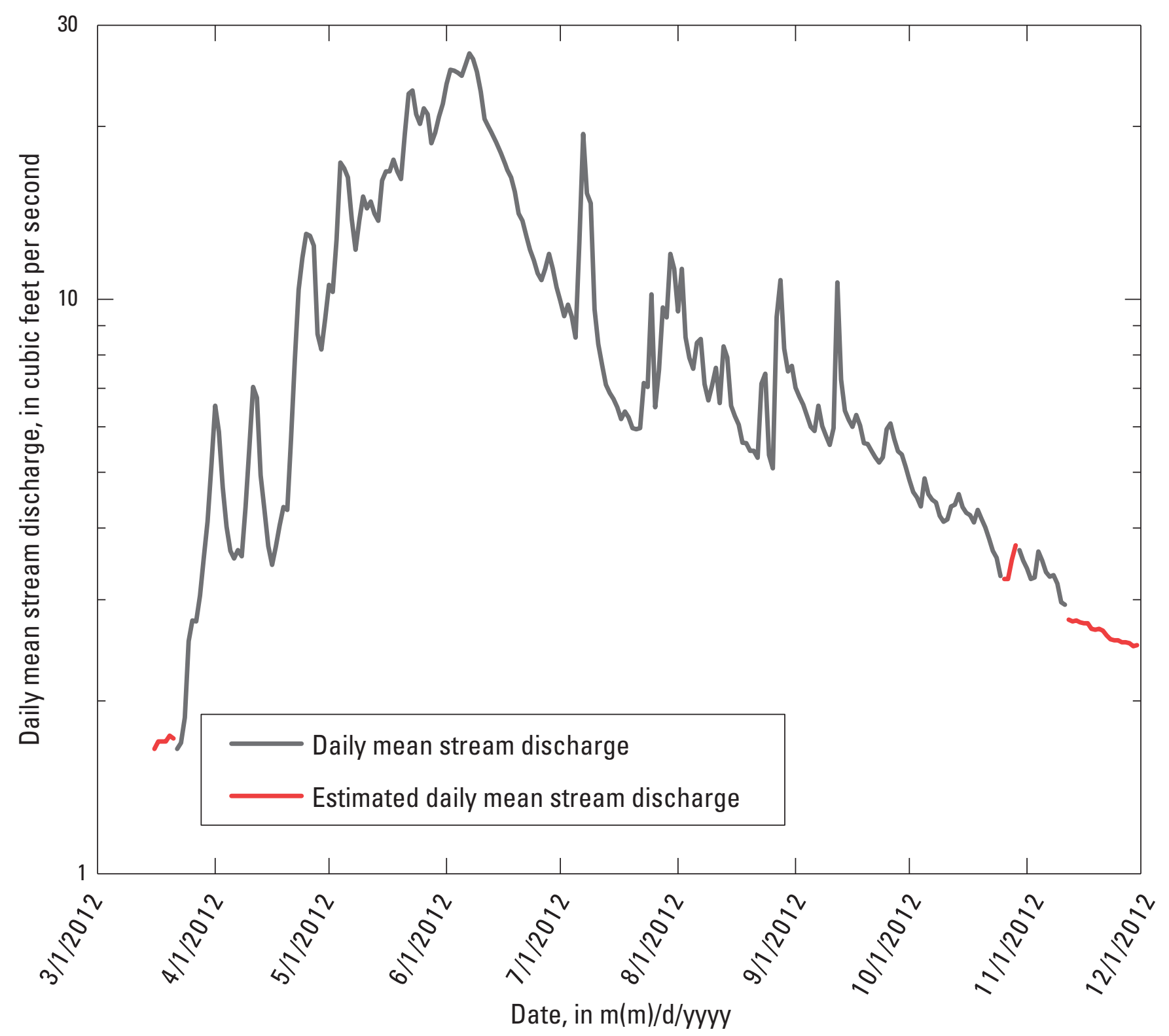

Figure 6. Graph showing stream discharge hydrograph at U.S. Geological Survey (USGS) station 06714800 in Colorado (CO) during March-December 2012. (From USGS, 2019b).

Service, 2013a). During this sampling in late June 2012, the Vidler Tunnel was actively importing water from the Peru Creek watershed. At that time, metal concentrations were derived from mixing imported Peru Creek water with native groundwater that naturally flows into the tunnel.

Mining operations commenced at the Waldorf Mine and mill site in about 1902 (Jensen, 1998) though first discoveries of silver in the Argentine district were reported as early as 1865 (Lovering, 1935). The Waldorf Mine and Wilcox Tunnel were driven to access the Commonwealth vein, and production of gold, silver, lead, and zinc is reported from the mine from about 1902 through 1927 (Lovering, 1935; Lovering and Goddard, 1950). Multiple water-quality studies have been performed at the site, and it was found to be a primary source of metals to Leavenworth Creek from (1) adit water drainage, (2) groundwater seeps and springs that emanate from the waste rock pile, and (3) dispersed mill tailings located north of the mine (U.S. Forest Service, 2013b). During high-flow sampling in June 2012, the Wilcox and Vidler Tunnels contributed almost equal amounts of zinc load to Leavenworth Creek (U.S. Forest Service, 2013a, tables 4-2B and 4-3B). This same sampling indicated that metal loads in Wilcox adit drainage water were about 50 to 100 times greater than loads from seeps and springs measured at the base of the Waldorf waste piles (U.S. Forest Service, 2013a). Leaching studies of mine waste from the Waldorf site ranked it second behind waste from the Santiago Mine in terms of generation of acid, specific conductance, and dissolved sulfate and selected trace metals (Hageman, 2004). 
The Santiago Mine and mill are located approximately $1 \mathrm{~km}(0.62$ mile) northwest and upslope from the Waldorf and Wilcox sites (fig. 3). No samples were collected during this study at the Santiago Mine or mill, but mining there contributed to waste streams at the Waldorf and Wilcox sites. The Santiago and Waldorf Mines both access the Commonwealth vein (Lovering, 1935), and mine workings are presumably interconnected (Pearson and others, 1997). The history of the Santiago Mine and mill is not well known, but production of gold, silver, lead, copper, and some zinc from veins is reported from about 1900 through 1928 (Lovering, 1935). The Santiago mill was constructed in 1935 and operated until as late as 1983 (Long Hoeft Architects, 2001, cited in U.S. Forest Service, 2013b). Prior to construction of the Santiago mill, an aerial tramway transported ore from the Santiago Mine to the Waldorf Mine and mill for processing (Lovering, 1935). Thus, some waste at the Waldorf site may be from the Santiago Mine (Pearson and others, 1997). Water-quality investigations at the Santiago Mine and mill site are limited (U.S. Forest Service, 2013b). Water-leaching studies of mine waste at the site ranked it first in terms of generation of acid, specific conductance, and elevated sulfate and selected trace metal concentrations relative to 12 other samples collected from nearby mining districts (Hageman, 2004).

Multiple water-quality studies in Leavenworth Creek are summarized by the U.S. Forest Service (2013a, b). Those most relevant to this study include Malem (2006), Fey and Wirt (2007), McDougal and Wirt (2007), and Story (2009).

An investigation of hydrogeochemical interactions within the Waldorf Mine dump identified three different types of water contributing to the dump: groundwater from the mine portal, upward flow of regional groundwater from fractures into the base of the dump, and infiltration of precipitation. This information contributed to various remediation scenarios recommended by the study (Malem, 2006). Tracer-dilution, mass-loading studies were conducted during 2002 and 2003 in a study reach extending from about the Vidler Tunnel inflow to downstream from the dispersed left-bank tailings (Fey and Wirt, 2007). The goal was to determine whether rerouting the Wilcox Tunnel discharge to flow around, rather than over and through the Waldorf waste piles, reduced metal load to Leavenworth Creek. The results indicated that after rerouting the Wilcox Tunnel discharge, zinc and copper loads were equal to if not greater than the previous year, partially from high snow pack and higher flow in the Wilcox Tunnel in 2003. The study identified the mine tunnel and diffuse seeps in wetland areas (upstream and downstream) from the tunnel and "leaching of the dispersed tailings" as primary sources of copper and zinc to the stream. The study concluded that the minewaste dump was not a major source of loading to the stream. A related study reported reduction in flow from seeps at the base of the Waldorf waste piles after rerouting the Wilcox Tunnel flow around the waste piles (McDougal and Wirt, 2007).

Story (2009) examined relations between benthic invertebrate abundance and surface-water and hyporheic zone water quality in a 1-km reach of Leavenworth Creek located near the upper kilometer of our study reach and containing the Vidler Tunnel inflow. The study indicated upwelling groundwater on both banks of the creek throughout the reach and generally greater concentrations of zinc, copper, and cadmium in hyporheic zone water than in surface water indicating that groundwater was contributing to surface-water metal concentrations in the study reach. The highest zinc and cadmium concentrations were observed in hyporheic and surface-water samples collected where the Vidler Tunnel flows into Leavenworth Creek. (Note: this location coincides with site LC689-L [fig. 4; table 1].)

High-flow sampling conducted in June 2012 by the Forest Service concluded that the three primary sources of metal (primarily zinc) in Leavenworth Creek were the Vidler Tunnel, the Waldorf adit (also known as the Wilcox Tunnel), and the dispersed tailings from the Waldorf mill. During this period, the Vidler Tunnel was actively importing water from the Peru Creek watershed. Other sources, including seeps at the base of the Waldorf waste piles, were minor contributors to metal loads in the creek (U.S. Forest Service, 2013a).

Other studies show potential metal inputs downstream from the extent of the study reach that are important to consider in the context of attaining water-quality standards in Leavenworth Creek but that were outside the scope of the current study (U.S. Forest Service, 2013b, charts 3-2, 3-3, 3-4).

\section{Methods}

Preparation for, and execution of, the synoptic sampling in 2012 took place during several field campaigns (table 2). In June 2012, two water-quality sondes and ISCO automatic samplers were installed at two locations in Leavenworth Creek to monitor diel cycling in the stream. In July and August, reconnaissance for, and execution of, the synoptic sampling was conducted. This effort included reconnaissance to select stream and inflow sites; installation and operation of recording sondes and ISCO automatic samplers at selected sites; injection of sodium bromide tracer to determine stream discharge; collection of water-quality samples from stream sites, direct inflows to the stream, mine tunnels, seeps from the bottom of the waste pile, tributaries, and sniffers installed in the substream hyporheic zone; determination of field water-quality properties; and processing of samples for chemical analysis (table 2). USGS station ID numbers, site ID descriptions, and field ID numbers for all sites used during this study are in table 1. Hereinafter, sites are referenced by field IDs for brevity.

Continuous recording water-quality sondes were used to measure $\mathrm{pH}$, temperature, specific conductance, and sometimes dissolved oxygen (table 3). During the June 20-22, 2012 diel sampling, two sondes that included all four properties were installed at sites LV1 (fig. 4) and LV2 (fig. 3). The sondes were calibrated according to the specifications of Gibs and others (2012) and recorded data every 15 minutes, starting and finishing at times parallel to ISCO operation at each site. 
Table 1. U.S. Geological Survey station identification numbers, site identification descriptions, and field identification numbers.

[Data can be accessed in the National Water Information System (U.S. Geological Survey, 2019d) using the station numbers in the first column. USGS, U.S. Geological Survey; ID, identification number; NWIS, National Water Information System; LC\#\#\#, or LC \#\#\#\#, Leavenworth Creek where \#\#\#\# is number of meters downstream from injection site; Leav Ck, Leavenworth Creek; m, meters; ds, downstream; fr, from; inj, injection; pt, point; lft, left; rt, right; Wcx T, Wilcox tunnel; VDLR, Vidler; WMA, Wilcox mine adit; WMDS, Waldorf mine dump seep; LVT, Leavenworth tributary; S, South (in site ID column); -S, stream site (in field ID column); -L, left bank inflow; -R, right bank inflow; SNIF, hyporheic sniffer site; tun, tunnel; LC1785-A and LC1785-B are two separate inflows at the same location; T0,T1, T2, T3, are "transient" sites where tracer injection equipment (T0), or continuous sampling and recording equipment $(\mathrm{T} 1, \mathrm{~T} 2, \mathrm{~T} 3)$ was installed]

USGS station ID

393741105455301

393742105455301

393743105455301

393744105455001

393745105455001

393747105454901

393748105454901

393750105454901

393753105454801

393756105454701

393758105454701

393759105454701

393801105454601

393804105454301

393805105454201

393806105454101

393806105454102

393807105454001

393807105454002

393808105453901

393808105453902

393808105453903

393809105453901

393809105453902

393810105453901

393811105453801

393812105453801

393812105453802

393814105453701

393816105453301

393818105453101

393818105453001

393819105452901

393820105452801

393820105452701

393821105452501

393822105452501

393822105452502

393822105452503

393822105452401

393823105452201

393823105452202

393824105452101

393824105452102

393825105452001

393825105451801
Site identification description in NWIS

LC-0-S T0 Leav Ck at tracer injection point

LC-55-S Leavenworth Ck 55m ds fr inj pt

LC-65-L Leav Ck Left bank inflow 65m ds fr inj

LC-177-S Leavenworth Ck $177 \mathrm{~m}$ ds fr inj

LC-187-R Leav Ck Right Bank Inflow 187m ds fr inj

LC-251-S Leavenworth Ck 251m ds fr inj

LC-279-L Leav Ck Left Bank Inflow 279m ds fr inj

LC-342-S T1 Leav Ck 342m ds fr Inj

LC-461-S Leavenworth Ck 461m ds fr Inj

LC-575-S Leavenworth Ck 575m ds fr Inj

LC-646-S Leavenworth Ck 646m ds fr Inj

LC-689-L Leav Ck Left bank inflow 689m ds fr inj

LC-747-S Leavenworth Ck 747m ds fr Inj

LC-869-S Leavenworth Ck 869m ds fr Inj

LC-925-L Leav Ck Left bank inflow 925m ds fr inj

LC-963-S Leavenworth Ck 963m ds fr Inj

LC-978-L Leav Ck Left bank inflow 978m ds fr inj

LC-998-L Leav Ck Left bank inflow 998m ds fr inj

LC-1037-R Leav Ck Rt Bank Inflow 1037m ds fr inj

LC-1065-S Leavenworth Ck 1065m ds fr Inj

LC-1069-L Leav Ck Lft bank inflow 1069m ds fr inj

LC-1070-R Leav Ck Rt Bank Inflow 1070m ds fr inj

LC-1089-L Leav Ck Lft bank inflow 1089m ds fr inj

LC-1118-R Leav Ck Rt Bank Inflow 1118m ds fr inj

LC-1137-S T2 Leavenworth Ck 1137m ds fr Inj

LC-1178-S Leavenworth Ck 1178m ds fr Inj

LC-1203-L Leav Ck Lft bk inf 1203m ds fr inj Wcx T

LC-1204-L Leav Lft bank inflow 1204m ds fr inj

LC-1282-S Leavenworth Ck 1282m ds fr Inj

LC-1417-S Leavenworth Ck 1417m ds fr Inj

LC-1491-S Leavenworth Ck 1491m ds fr Inj

LC-1520-L Leav Ck Lft bank inflow 1520m ds fr inj

LC-1558-S Leavenworth Ck 1558m ds fr Inj

LC-1590-R Leav Ck Rt Bank Inflow 1590m ds fr inj

LC-1607-L Leav Ck Lft bank inflow $1607 \mathrm{~m}$ ds fr inj

LC-1660-S Leavenworth Ck 1660m ds fr Inj

LC-1689-L Leav Ck Lft bank inflow 1689m ds fr inj

LC-1693-S Leavenworth Ck 1693m ds fr Inj

LC-1705-R Leav Ck Rt Bank Inflow 1705m ds fr inj

LC-1767-S Leavenworth Ck 1767m ds fr Inj

LC-1785A-R Leav Ck Rt Bank Inflow 1785m ds fr inj

LC-1785B-R Leav Ck Rt Bank Inflow 1785m ds fr inj

LC-1832-S Leavenworth Ck 1832m ds fr Inj

LC-1843-L Leav Ck Lft bank inflow $1843 \mathrm{~m}$ ds fr inj

LC-1881-S Leavenworth Ck 1881m ds fr Inj

LC-1977-S Leavenworth Ck 1977m ds fr Inj
Field ID (figs. 3 and 4)

LC0-S, T0

LC55-S

LC65-L

LC177-S

LC187-R

LC251-S

LC279-L

LC342-S, T1

LC461-S

LC575-S

LC646-S

LC689-L

LC747-S

LC869-S

LC925-L

LC963-S

LC978-L

LC998-L

LC1037-R

LC1065-S

LC1069-L

LC1070-R

LC1089-L

LC1118-R

LC1137-S, T2

LC1178-S

LC1203-L

LC1204-L

LC1282-S

LC1417-S

LC1491-S

LC1520-L

LC1558-S

LC1590-R

LC1607-L

LC1660-S

LC1689-L

LC1693-S

LC1705-R

LC1767-S

LC1785A-R

LC1785B-R

LC1832-S

LC1843-L

LC1881-S

LC1977-S 
Table 1. U.S. Geological Survey station identification numbers, site identification descriptions, and field identification numbers.Continued

[Data can be accessed in the National Water Information System (U.S. Geological Survey, 2019d) using the station numbers in the first column. USGS, U.S. Geological Survey; ID, identification number; NWIS, National Water Information System; LC\#\#\#, or LC-\#\#\#, Leavenworth Creek where \#\#\#\# is number of meters downstream from injection site; Leav Ck, Leavenworth Creek; m, meters; ds, downstream; fr, from; inj, injection; pt, point; lft, left; rt, right; Wcx T, Wilcox tunnel; VDLR, Vidler; WMA, Wilcox mine adit; WMDS, Waldorf mine dump seep; LVT, Leavenworth tributary; S, South (in site ID column); -S, stream site (in field ID column); -L, left bank inflow; -R, right bank inflow; SNIF, hyporheic sniffer site; tun, tunnel; LC1785-A and LC1785-B are two separate inflows at the same location; T0,T1, T2, T3, are "transient" sites where tracer injection equipment (T0), or continuous sampling and recording equipment $(\mathrm{T} 1, \mathrm{~T} 2, \mathrm{~T} 3)$ was installed]

\begin{tabular}{clc}
\hline USGS station ID & \multicolumn{1}{c}{ Site identification description in NWIS } & Field ID (figs. 3 and 4) \\
\hline 393826105451701 & LC-1982-R Leav Ck Rt Bank Inflow 1982m ds fr inj & LC1982-R \\
393826105451601 & LC-1993-L Leav Ck Lft bank inflow 1993m ds fr inj & LC1993-L \\
393827105451601 & LC-2023-S T3 Leavenworth Ck 2023m ds fr Inj & LC2023-S, T3 \\
393827105451501 & LC-2036-R Leav Ck Rt Bank Inflow 2036m ds fr inj & LC2036-R \\
393827105451502 & LC-2053-S Leavenworth Ck 2053m ds fr Inj & LC2053-S \\
393828105451401 & LC-2074-R Leav Ck Rt Bank Inflow 2074m ds fr inj & LC2074-R \\
393815105453401 & Hyporheic sampler Sniffer \#1 at 1400m ds fr inj & SNIF1 \\
393810105453902 & Hyporheic sampler Sniffer \#2 at 1137m ds fr inj & SNIF2 \\
393814105453702 & Hyporheic sampler Sniffer \#3 at 1282m ds fr inj & SNIF3 \\
393751105460201 & Vidler Tunnel outfall at Pipe-Left Bank Inflow & VDLR \\
393816105455901 & WMA-01 Wilcox Tunnel at land surface-Lft Bank Inf & WMA-01 \\
393814105455701 & WMDS-01 South seep from Waldorf Mine waste pile & WMDS-01 \\
393814105455601 & WMDS-02 North seep from Waldorf mine waste pile & WMDS-02 \\
393808105460501 & LVT-04 Tributary to Leavenworth-Left Bank Inflow & LVT-04 \\
393758105460301 & LVT-05 Trib to Leav Ck S of Vidler tun Lft Bnk Inf & LVT-05 \\
393812105453803 & Leavenworth Cr Diel Sampling Site LV1 June2012 & LV1 \\
393947105442501 & Leavenworth Cr Diel Sampling Site LV2 June2012 & LV2
\end{tabular}

During the August diel and synoptic sampling, one sonde, having all four properties, and two sondes, able to measure temperature, $\mathrm{pH}$, and specific conductance, were calibrated as described for the June sampling and deployed at sites LC1137-S, T2 (T2); LC2023-S, T3 (T3); and LC1203-L. $\mathrm{T} 2$ and $\mathrm{T} 3$ are transient sites where continuous recording and sampling equipment were installed. The three-property sonde at T2 was deployed from approximately 1430 hours on August 27, 2012, to 1650 hours on August 30, 2012, and recorded data every 10 minutes. The four-property sonde at T3 was deployed from approximately 1810 hours on August 27, 2012, to 1450 hours on August 30, 2012, and recorded data every 10 minutes. The three-property sonde at LC1203-L was deployed from approximately 1530 hours on August 27, 2012, to 1705 hours on August 30, 2012, and recorded data every 5 minutes.

ISCO automatic samplers were used to collect approximately 750 milliliters (mL) of sample at programmed sampling times at sites LV1 and LV2 from June 20 to 22, 2012, and at three sites, LC342-S, T1 (T1); T2; and T3, from August 27 to 30, 2012, (table 2). All ISCO bottles at sites LV1, LV2, T2, and T3 were acid rinsed in dilute nitric acid prior to transport to the field. The ISCO bottles for site T1 were not acid rinsed prior to use. All ISCO bottles were additionally rinsed with stream water before deployment. The ISCO at site LV1 collected samples every 1 hour and 45 minutes from
1530 hours on June 20 through 0900 hours on June 22. At site LV2, the ISCO collected samples every 1 hour and 45 minutes from 1715 hours on June 20 through 0930 hours with a final grab sample collected at 1100 hours on June 22. Samples were filtered and acidified (as described for the August ISCO operation) on June 22 when the ISCOs were retrieved from the field.

From August 27 to 30, automated ISCO samplers installed at sites T1, T2, and T3 experienced some technical difficulties (loss of power resulting in failure to sample, for example, or failure of ISCO to start as programmed) that limited the number of samples collected. At site T1, the ISCO collected hourly samples from 1500 hours on August 29 through 1400 hours on August 30. At site T2, the ISCO collected hourly samples from 1400 hours on August 28 through 1400 hours on August 30. At site T3, the ISCO collected hourly samples from 1700 hours on August 27 through 1500 hours on August 28 and from 1520 hours on August 29 through 1320 hours on August 30. Every 24 hours, ISCOs were reset and samples collected during the previous 24 hours were filtered through 0.45 -micrometer $(\mu \mathrm{m})$ filters using general guidelines from the USGS National Field Manual (Wilde and others, 2002).

For each ISCO, a single high-capacity capsule filter was used for all 24 ISCO bottle samples in a full ISCO, a slight variation from recommendations of the USGS National Field Manual (Wilde and others, 2002) of one filter per sample. 
Table 2. Schedule and description of field work in Leavenworth Creek, Colorado, June-August 2012.

[See table 1 for a list of all sample locations and correlated U.S. Geological Survey site identification numbers. ISCO, automatic sampling device; LV1 and LV2, two sites on Leavenworth Creek, see figures 3 and 4; LC\#\#\#, Leavenworth Creek sampling sites where \#\#\#\# designates downstream distance in meters from the beginning of the study reach; -S, stream site; T0, T1, T2, T3, "transient" sites where tracer injection equipment (T0) or continuous sampling and recording equipment (T1, T2, and T3) was installed during August 27-30, 2012, see figs. 3 and 4 for locations]

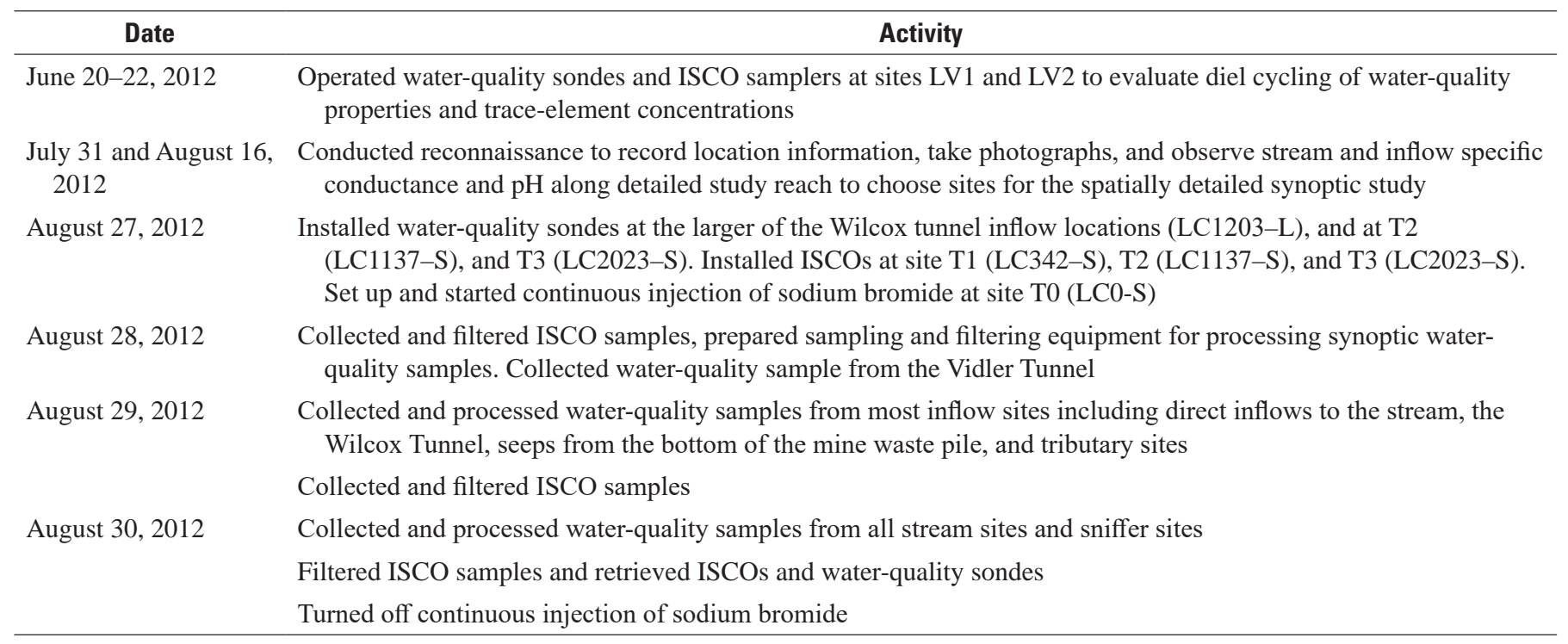

In addition, Wilde and others (2002) recommend at least 1 liter $(\mathrm{L})$ of rinse to remove potential contaminants remaining from filter manufacturing processes, which was not practical because the ISCO bottles contained only approximately 750 $\mathrm{mL}$ of sample. The modified procedure included rinsing the capsule filter with approximately $200-400 \mathrm{~mL}$ of water during double rinsing of a $125 \mathrm{~mL}$ sample bottle for each ISCO-bottle sample. The sample bottle was then filled leaving space to add nitric acid (if used). Between filtration of each ISCO-bottle sample, pumping continued to evacuate almost all sample water from the capsule filter until only a few drips were seen, when bottle rinsing and filtering of the next ISCO-bottle sample commenced. During the June 20-22 diel sampling, only one aliquot of filtered water was collected from each ISCO bottle and acidified to $\mathrm{pH}$ less than 2 with ultra-trace 15.8 normal nitric acid to preserve for analysis of trace- and majorelement content. During the August diel sampling, two filtered 125-mL samples were collected from each ISCO bottle; one was preserved for trace- and major-element analysis, and a second was filtered, but not acidified, for analysis of anions.

Reconnaissance for synoptic sampling took place July 31 and August 16 when team members walked the study reach to measure the length and record spatial coordinates of the reach; record downstream variations in field properties $(\mathrm{pH}$, temperature, and specific conductance) of the stream; and identify, locate, and characterize field properties of all substantial inflows to the stream (table 2). This information was used to choose stream and inflow sampling locations for the tracer injection and synoptic sampling event and to calculate appropriate amounts and duration of tracer injection for the study.
Stream discharge was determined using dilution of injected tracer, velocity meter measurements, volumetric measurement (Turnipseed and Sauer, 2010), and visual estimates at the two seeps at the base of the Waldorf Mine waste pile where physical measurement was impractical and subject to large error. A known mass flow of sodium bromide was added to the stream at the top of the reach (site LCO-S, T0) to enable calculation of stream discharge at all stream-sampling sites using bromide concentrations and equations presented in Kilpatrick and Cobb (1985) and Kimball and others (1999). The continuous injection rate of sodium bromide solution was $49.63 \mathrm{~mL}$ per minute. The concentration of bromide in the injection solution was 232.25 grams per liter. Four or five significant figures in these concentrations are justified as both values were measured gravimetrically. Four stream-discharge measurements were made using acoustic doppler velocimetry (SonTek Flow Tracker One) and cross-section methods outlined in Turnipseed and Sauer (2010). These measurements were compared with tracer-dilution determined stream discharge as discussed in the section "Stream Discharge Calculations from Dilution of Tracer.”

During synoptic sampling on August 28-30, 2012, grab samples were collected at all locations using 1.75-L milk jugs prerinsed with dilute nitric acid and deionized water and triple-rinsed with sample water following USGS guidelines (Wilde, 2006). The narrow stream and small inflow and seep channels did not require width and depth integration. Eleven right-bank inflows and 15 left-bank inflows were sampled where they entered Leavenworth Creek. In addition, waterquality samples were collected at two tunnel sites (Wilcox, WMA-01; and Vidler, VDLR), two seeps at the base of waste 
Table 3. Constituents and reporting levels included in water-quality analysis of samples collected at Leavenworth Creek, Colorado, June and August 2012.

[NA, not applicable; mg/L, milligrams per liter; $\mu \mathrm{g} / \mathrm{L}$, micrograms per liter; NM, not measured]

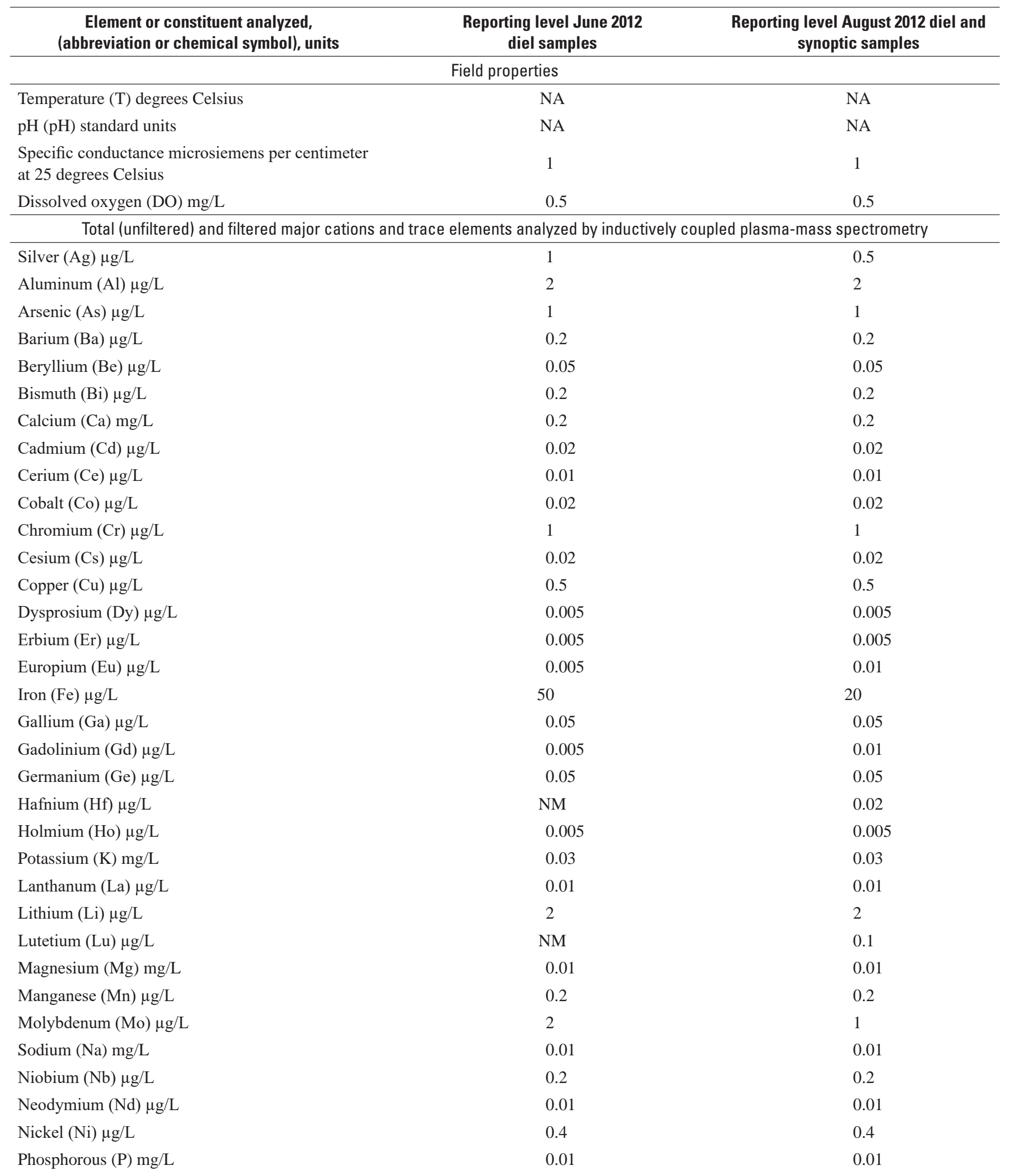


Table 3. Constituents and reporting levels included in water-quality analysis of samples collected at Leavenworth Creek, Colorado, June and August 2012. - Continued

[NA, not applicable; mg/L, milligrams per liter; $\mu \mathrm{g} / \mathrm{L}$, micrograms per liter; NM, not measured]

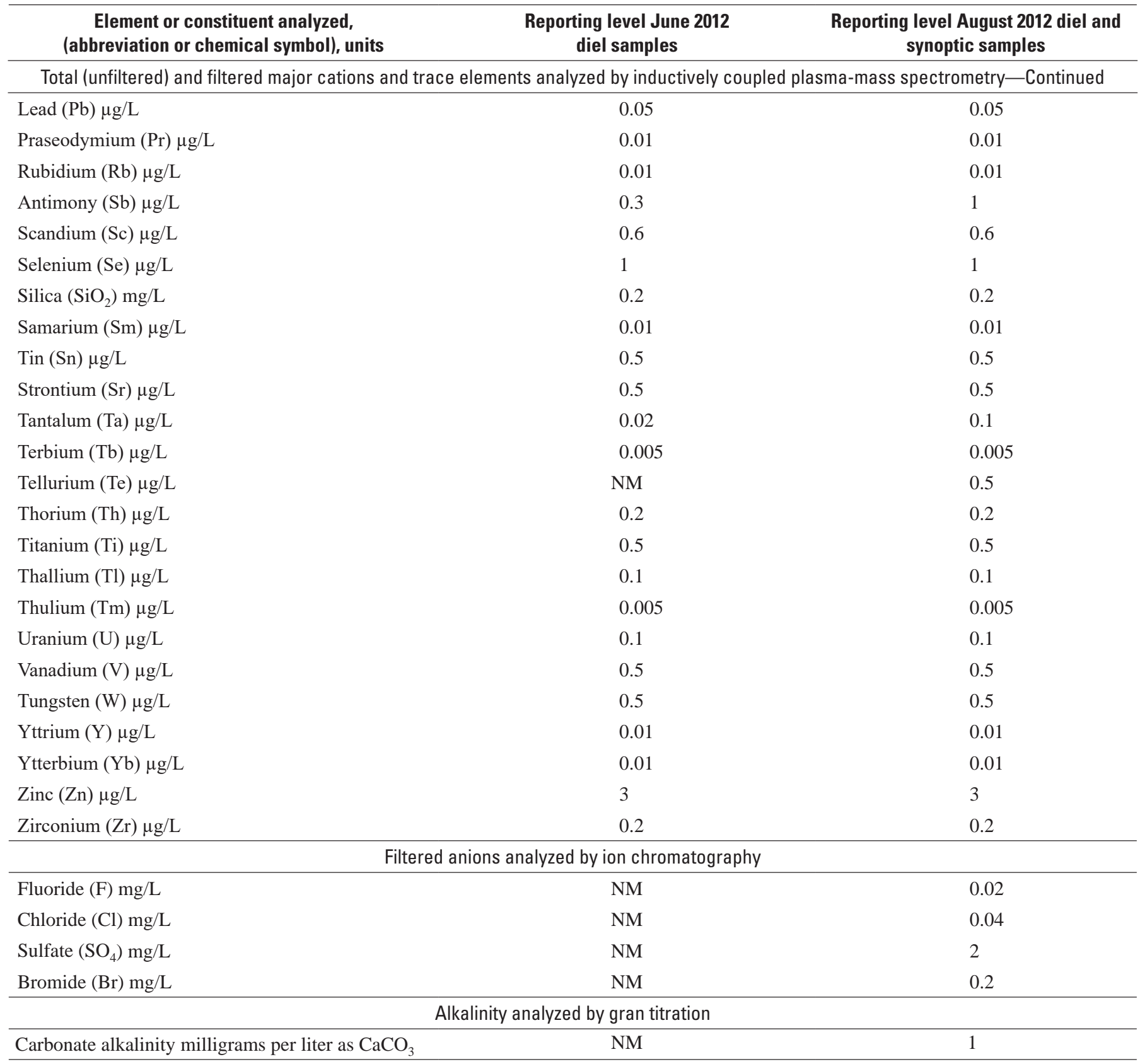

material associated with the Waldorf Mine (WMDS-01 and WMDS-02), two tributary inflows (LVT-04 and LVT-05), and three hyporheic sniffer sites (SNIF1, 2, and 3) (fig. 4). Most inflow sites were sampled on August 29; Vidler Tunnel was sampled on August 28. All stream sites were sampled at 1200 hours on August 30. The hyporheic sniffer sites were sampled the morning of August 30. Hyporheic sniffers are small piezometers installed into the streambed. A nylon tube extending to the bottom of the sniffer facilitated collection of water-quality samples and comparison of water pressure in the hyporheic zone at the bottom of the sniffer to that in the stream (Wanty and Winter, 2000). A peristaltic pump was attached to the nylon tube to pump each sniffer until water ran clear, at which time samples were collected. In some cases, there was sufficient (artesian) pressure in the sniffers for substream water to freely flow from the tube. 
Temperature of the sample source was measured using alcohol in glass thermometers at the time of sample collection. Water-quality properties including $\mathrm{pH}$ and specific conductance were measured in each individual synoptic sample during sample processing. Milk jug samples were divided into four 125-mL aliquots: (1) an unfiltered, acidified (nitric acid, $\mathrm{pH}$ less than 2) sample for unfiltered major and trace elements; (2) a filtered $(0.45 \mu \mathrm{m})$, acidified (nitric acid, $\mathrm{pH}$ less than 2) sample for filtered major and trace elements; (3) a filtered $(0.45 \mu \mathrm{m})$ sample for filtered major anions; and (4) a filtered $(0.45 \mu \mathrm{m})$ sample for alkalinity. Cleaning, rinsing, and filtration utilized procedures as described in Wilde and others (2002) and Wilde $(2004,2006)$ and included using dedicated tubing and filters for each sample, rinsing each bottle three times with portions of water to be collected, collecting unfiltered samples first, and precleaning and preparing bottles appropriate for each aliquot type.

Total (unfiltered) and filtered major and trace elements were analyzed using inductively coupled plasma-mass spectrometry (ICP-MS) at a USGS laboratory in Denver, Colo., associated with the USGS Mineral Resources Program. As many as 58 constituents were analyzed using methods from Lamothe and others (2002); constituent list and reporting levels are included in table 3.

Filtered anions (fluoride, chloride, sulfate, and bromide) were analyzed by ion chromatography (table 3), and alkalinity was analyzed by gran titration (table 3 ) at the USGS Utah Water Science Center Laboratory in Salt Lake City, Utah, using methods from Barringer and Johnsson (1989), Brinton and others (1996), and Kimball and others (1999). Alkalinity samples were preserved by refrigeration until analysis.

Quality-control procedures included collection and analysis of two field blank samples using certified blank water, collection and analysis of two field replicates, analysis of standard reference samples (SRS), and assessment of laboratory and field variability and laboratory bias as described in the "Quality Assurance and Quality Control" section of this report. All water-quality and stream-discharge data are stored in the National Water Information System (NWIS) database (https://doi.org/10.5066/F7P55KJN; U.S. Geological Survey, 2019d) and retrievable using the USGS station IDs for each field site listed in table 1. Constituents affected by injection of tracer into the stream (specific conductance; filtered and unfiltered sodium and bromide concentrations in streams; hyporheic sniffer; and ISCO samples) are reported in a USGS data release (Walton-Day and others, 2021).

Instantaneous mass (metal) loads were calculated for filtered zinc and for total (unfiltered) concentrations of copper, lead, manganese, and zinc at 26 stream sites. Instantaneous mass loads are the product of concentration in milligrams per liter or micrograms per liter and stream discharge in liters per second (yielding instantaneous mass load in milligrams per second or micrograms per second) and multiplied by appropriate conversion factors ( 0.0864 for milligrams per second and 0.0000864 for micrograms per second) to obtain load, in kilograms per day; or by 0.0864 for micrograms per second to obtain load in grams per day. Stream-discharge values calculated from bromide concentrations are available in Walton-Day and others (2021) and were used to calculate instantaneous mass loads. Stream-discharge values stored in NWIS were truncated to two significant figures due to constraints in NWIS and cannot be used to recreate the instantaneous mass loads reported herein. Zinc concentrations were below reporting levels of 3 micrograms per liter $(\mu \mathrm{g} / \mathrm{L})$ in filtered samples from LC0-S to LC747-S and in total (unfiltered) samples from LC0-S to LC-646 S. For these samples, the reporting level was used to calculate load and the average load value in these reaches was plotted on graphs.

\section{Quality Assurance and Quality Control}

Quality-assurance and quality-control activity included collection and review of results of field blank and replicate samples, laboratory analysis of SRS and laboratory replicate samples, and visual inspection and graphing of field results. Replicate samples and SRS were evaluated for variability using percent relative standard deviation (RSD) for the average of replicate analyses. Standard reference samples were evaluated for bias using percent recovery of the sample analysis compared to the most probable value (MPV) for analytes. The data-quality objective for laboratory and field variability in this study was percent RSD less than or equal to 15 percent. The data-quality objective for bias in ICP-MS samples recommended by the laboratory and presented herein was 20 percent, or values of percent recovery between 80 and 120 percent.

Field quality-assurance samples included two blank and two replicate samples with two fractions (unfiltered and filtered) analyzed. An additional blank sample was evaluated to test for contamination of the acid used to preserve field samples. Both blank samples for unfiltered and filtered fractions tested less than the reporting level for all analytes except for filtered beryllium, which had a concentration just greater than the reporting level of $0.05 \mu \mathrm{g} / \mathrm{L}$ (table 3). Most field samples had beryllium concentrations less than 0.2 , except for the Wilcox Tunnel samples, the seeps from the Waldorf waste pile, and inflow LC1204-L (the inflow to Leavenworth Creek that contained Wilcox Tunnel water and Waldorf seep water), indicating that slight beryllium contamination in the blank does not affect interpretation of field samples. All elements tested less than reporting levels in the blank water sample acidified using the field-sample-preservation acid indicating no contamination in the acid preservative. Field-sample replicates showed less than 15 percent RSD for all analytes where the sample concentration was greater than 10 times the reporting level in both unfiltered and filtered fractions from both samples (table 4). As expected, there was some greater variability noted in concentrations within 10 times the reporting level. Because this study is primarily interested in trace elements having elevated concentrations, higher variability near the reporting level is acceptable. 
To evaluate analytical variability and bias, laboratory quality assurance for ICP-MS analyses included replicate analyses of 2 field samples to evaluate analytical variability, and analysis of 10 USGS SRSs: T-131, T-173, T-183, T-185, T-201, T-207, T-209, M-178, AMW-3, and a 1:20.8 dilution of AMW-4 (table 4, USGS, 2019c). The SRSs are reference materials whose MPVs are median values calculated from results reported by laboratories participating in round robin evaluation (Long and Farrar, 1995; USGS, 2019c). The SRS samples are not certified reference materials, and the MPV values were calculated for each SRS by a different mix of laboratories and analytical methods from 1993 through 2012 (table 4). Thus, some of the SRSs were fresher than others at the time of analysis in 2012, and the predominant analytical methods used by participating laboratories have likely shifted over the timespan covered by the samples. In addition, not all constituents analyzed during this study were evaluated for bias, but all were evaluated for variability. Despite these potential limitations, comparison of analytical results with MPVs of SRSs allows evaluation over a range of concentrations in natural sample matrices and thus is more cost effective than a similar approach using certified standards, which typically do not have the advantage of natural sample matrices.

Evaluation of laboratory variability using multiple analyses of SRSs and two environmental samples (SNIF3 and LC2023-S, table 4) indicated less than 15 percent RSD for all analytes and all samples where results were greater than 10 times the reporting level except for hafnium, lithium,

Table 4. Summary of variability and bias evaluation of U.S. Geological Survey (USGS) standard reference samples and laboratory and analytical replicate samples, Leavenworth Creek, Colorado, June and August 2012.

[SRS, standard reference sample; ID, identification number; n, number of replicate analyses; \%, percent; LC\#\#\#-S, field site identification number from fig. 4 and table 1; RA, unfiltered acidified sample; NA, not applicable; FA, filtered acidified sample; T, (trace metal); Se, selenium; M, major element; AMW, acid mine water; Hf, hafnium; Li, lithium; P, phosphorous; >, greater than; Al, aluminum; Ba, barium; Zn, zinc; SNIF, hyporheic zone sniffer]

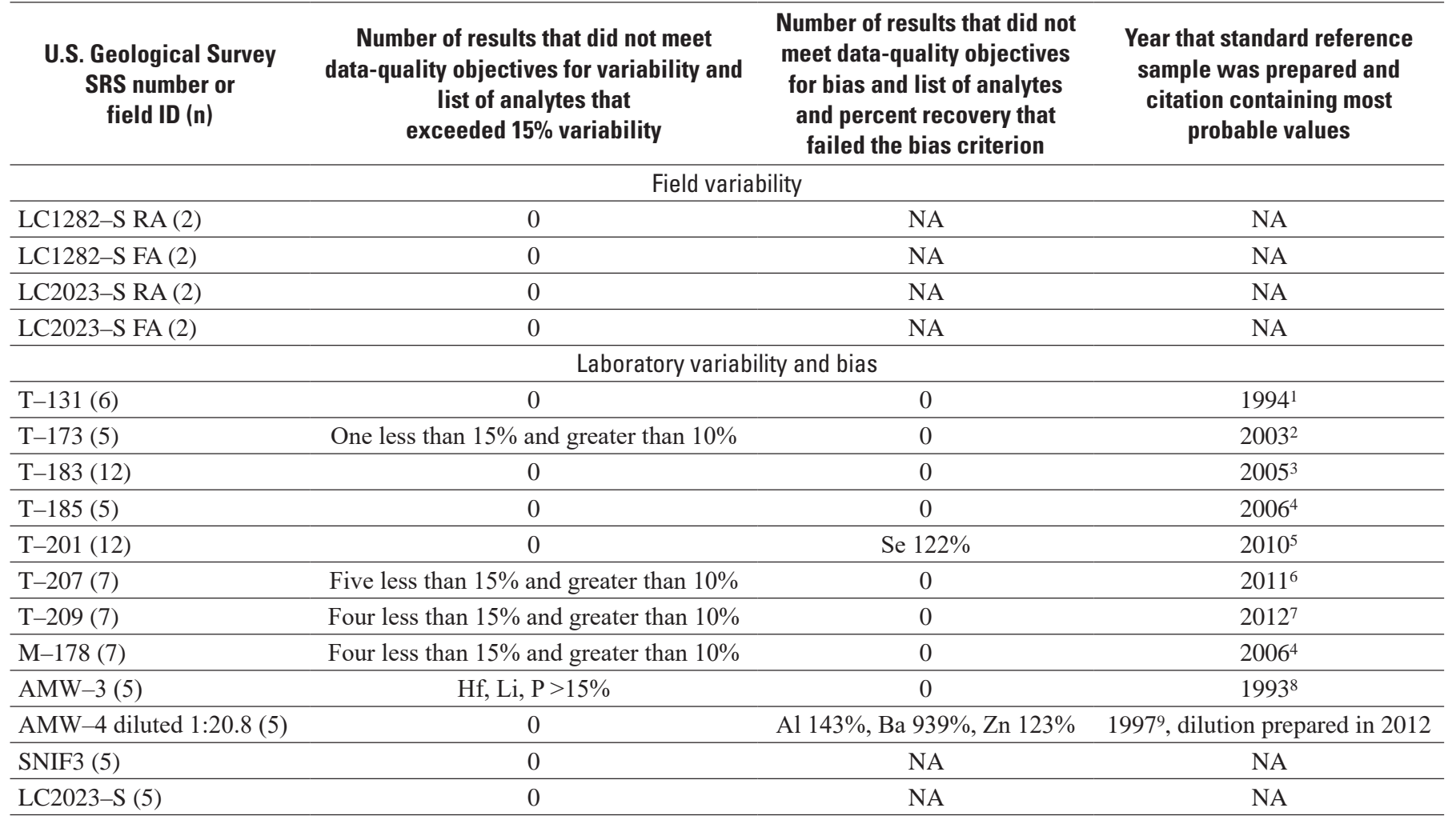

${ }^{1}$ Long and Farrar, 1995.

${ }^{2}$ Woodworth and Connor, 2003.

${ }^{3}$ U.S. Geological Survey, 2005.

${ }^{4}$ U.S. Geological Survey, 2006.

${ }^{5}$ U.S. Geological Survey, 2010.

6U.S. Geological Survey, 2011.

${ }^{7}$ U.S. Geological Survey, 2012.

${ }^{8}$ Long and Farrar, 1994.

${ }^{9}$ Farrar, 1998. 
and phosphorous in AMW-3 (table 4). This result does not affect interpretations presented in this study because these analytes are not discussed herein. Values of RSD were less than 10 percent for most analytes and samples, indicating strong control on laboratory variability (table 4). Evaluation of SRSs for laboratory bias where results were greater than 10 times the reporting level indicates that all analyses fell within 20 percent of the MPV except for selenium in SRS $\mathrm{T}-201$ (table 4) with an average reported selenium concentration $(11 \mu \mathrm{g} / \mathrm{L})$ that was 122 percent of the MPV $(9.02 \mu \mathrm{g} / \mathrm{L})$. In addition, the diluted AMW-4 sample showed exceedance of the bias data-quality objective for aluminum, barium, and zinc (table 4). Considering the age of the original sample (1997), these results are somewhat discounted. Also, because 9 of the 10 SRSs examined showed no issue with zinc concentrations, the AMW -4 results are further discounted. As expected, there was some greater variability noted in concentrations within 10 times the reporting level. Because this study is primarily interested in elements having elevated concentrations, higher variability near the reporting level is acceptable.

Review of diel data from June and August consisted of assessment of the presence or absence of diel cycles and outliers. In general, because these data were generally not relied on for quantitative analysis (other than calculation of percent increase in zinc concentration during diel cycling), the data-quality objectives for variability and bias were not rigorously tested. Time-series graphs of June diel trace-element data showed a few outliers likely caused from spurious contamination or laboratory variability; however, diel patterns were clearly discerned for some trace elements and, in general, not for major cations (calcium, magnesium, sodium, and potassium). The few outliers identified were retained in the dataset because there were no strong scientific reasons to delete them, and future users of the data may benefit from inclusion of all data.

For the August diel data, there was notable contamination in the ISCO samples collected at site T1, compared to data collected at T2 and T3. As mentioned in the "Methods" section, the sample bottles at site $\mathrm{T} 1$ were not acid rinsed prior to installation at the site, though they were copiously rinsed with stream water. Concentrations of arsenic, copper, iron, potassium, magnesium, sodium, lead, and uranium were consistently greater in samples collected at this site than in samples collected downstream at similar times at sites T2 and T3. Stream waterquality samples collected during synoptic sampling showed increasing concentrations moving from T1 to T2. Therefore, the T1 ISCO data for arsenic, copper, iron, potassium, magnesium, sodium, lead, and uranium, though retained in the NWIS database and available internally from USGS, are not publicly available because there was adequate scientific evidence indicating contamination of the site T1 ISCO bottles.

Review of the remaining August diel data at sites T1, T2, and T3 showed a few outliers in the data likely caused from spurious contamination or laboratory variability. In general, diel patterns were discerned for some trace elements and not for major cations. The few outliers identified were retained in the dataset because there were no strong scientific reasons to delete them, and future users of the data may benefit from inclusion of all data.

Review of stream profiles of trace-element concentrations resulting from synoptic sampling focused on the data presented herein for zinc, lead, copper, and manganese. Only one outlier was removed from these data for discussion purposes, as described in the section "Metal-Mass Loading Stream Profiles." The data point is retained in NWIS for the benefit of completeness of the dataset. A result-level comment is included with the data point to inform future data users that the point is an outlier.

In summary, results of quality-assurance and qualitycontrol procedures for this study indicate that almost all analytes interpreted in this study fell within data-quality objectives of 15 percent RSD for variability and plus or minus 20 percent for bias. One exception was the high bias for zinc concentrations (122 percent recovery) noted in the diluted sample of AMW-4. Zinc concentrations met data-quality objectives for the other nine SRSs evaluated, and zinc concentrations are considered usable with slight caution about potential high bias.

\section{Diel Cycling in June 2012}

Strong diel cycles occurred in Leavenworth Creek at sites LV1 and LV2 during an approximately 36-hour period June 20-22, 2012. Temperature, dissolved oxygen, and $\mathrm{pH}$ show diel signals with temperature and $\mathrm{pH}$ having minimum values near dawn and maximum values around 1600 hours, except at LV1 where maximum $\mathrm{pH}$ values occurred at approximately 1100 hours (fig. 7A-C). In contrast, minimum dissolved oxygen values occurred at approximately 1600 hours, and maximum values occurred at approximately 0830 hours at LV1 and 0730 hours at LV2. These patterns are very similar to those previously reported (fig. 2; Nimick and others, 2011). Diel fluctuation in stream discharge (fig. 7D) at the mouth of Leavenworth Creek (USGS station 06714800) is somewhat, but not directly, synchronous with dissolved oxygen. This diel stream discharge pattern results from variation in snowmelt contributions to the stream, where high-elevation snowmelt enters the stream during warmer parts of the day and is recorded at the streamgage at night, reflecting the travel time between snowmelt areas and the streamgage. The travel time between LV1 and LV2 and the USGS station 06714800 is unknown. It is likely the hydrographs at each site would show different timing because of different distances and travel times from where active snow melt occurs. Except for $\mathrm{pH}$, the diel cycles of water-quality properties at each site are almost identical (fig. 7A-C), indicating it is unlikely that these cycles are tied to the snowmelt hydrographs that are likely different at each site.

The diel fluctuations in temperature, $\mathrm{pH}$, and dissolved oxygen concentrations cause diel fluctuations in trace element concentrations, as illustrated by filtered zinc concentrations at sites LV1 and LV2 (fig. 8). Maximum concentrations occurred 

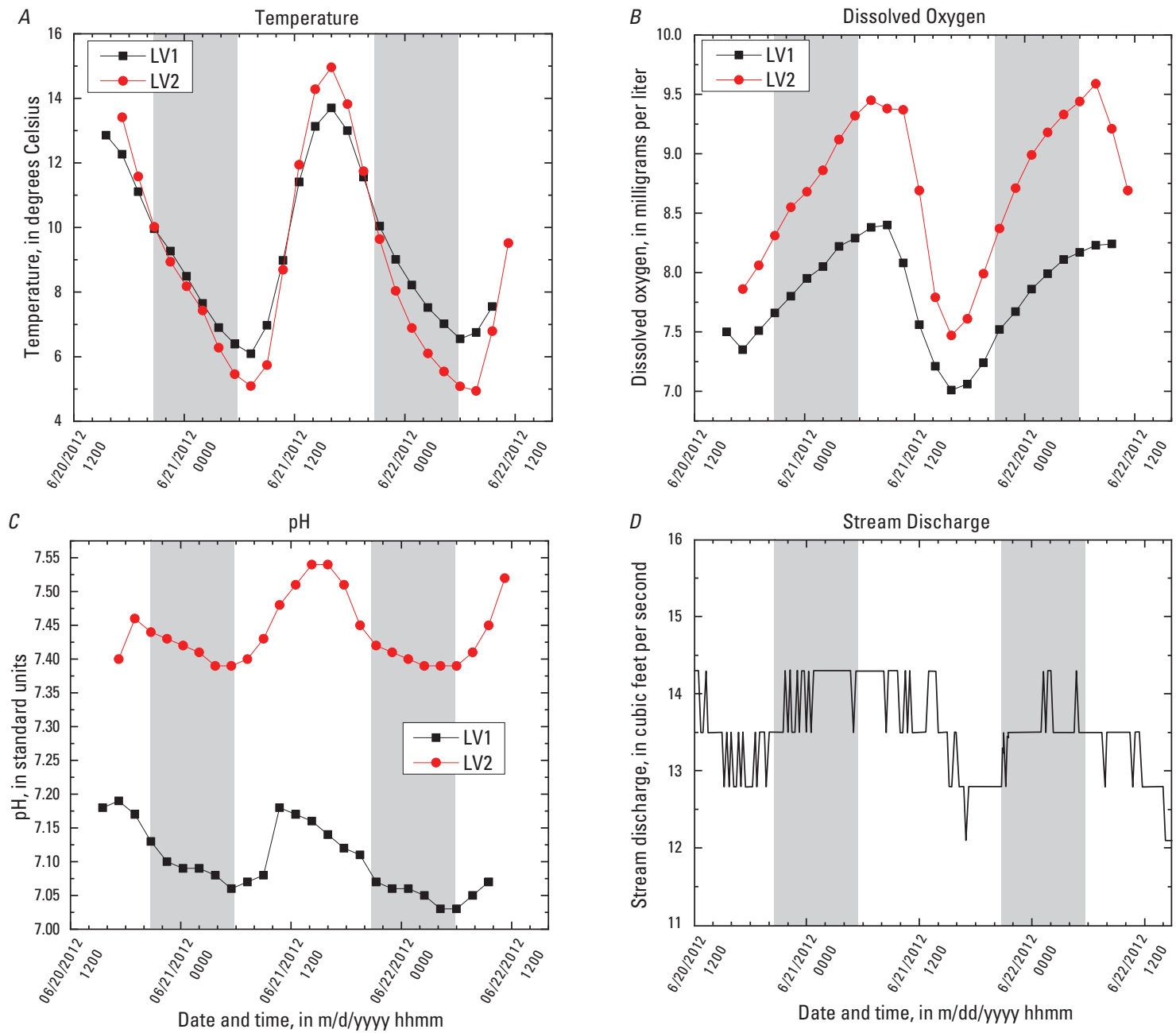

Figure 7. Graphs illustrating variation in $A$, temperature; $B$, dissolved oxygen; and $C$, pH at sites LV1 and LV2; and $D$, stream discharge at U.S. Geological Survey station 06714800, Leavenworth Creek, Colorado, June 20-22, 2012. The shaded areas of the graphs indicate nighttime hours (sunrise and sunset times from Sunrise Sunset, 2019a).

at the two sites during the nighttime, and minimum concentrations were during the daytime, which is consistent with results previously described (fig. 2). In addition to zinc, filtered concentrations of cadmium, cobalt, manganese, and yttrium showed strong diel fluctuations. It is interesting that, similar to the $\mathrm{pH}$ values at the two sites, minimum zinc concentrations occurred earlier in the day at the upstream site, LV1, than at the downstream site, LV2, likely indicating the importance of $\mathrm{pH}$ control over sorption processes at these sites. These diel fluctuations of zinc concentrations at sites LV1 and LV2 in June 2012 supported the decision to sample all stream sites during synoptic sampling at precisely 1200 hours on August 30, 2012.

\section{Diel Cycling, Tracer Dilution, Instantaneous Synoptic Sampling, and Metal Loading, August 2012}

Results discussed from the August sampling campaign include selected field property and elemental concentration data from sites instrumented to record diel cycling; calculations of stream discharge at each site using tracer dilution; individual stream-discharge measurements completed using acoustic-doppler velocimetry; and stream profiles of $\mathrm{pH}$, specific conductance, and selected trace-element concentrations and instantaneous loads. 


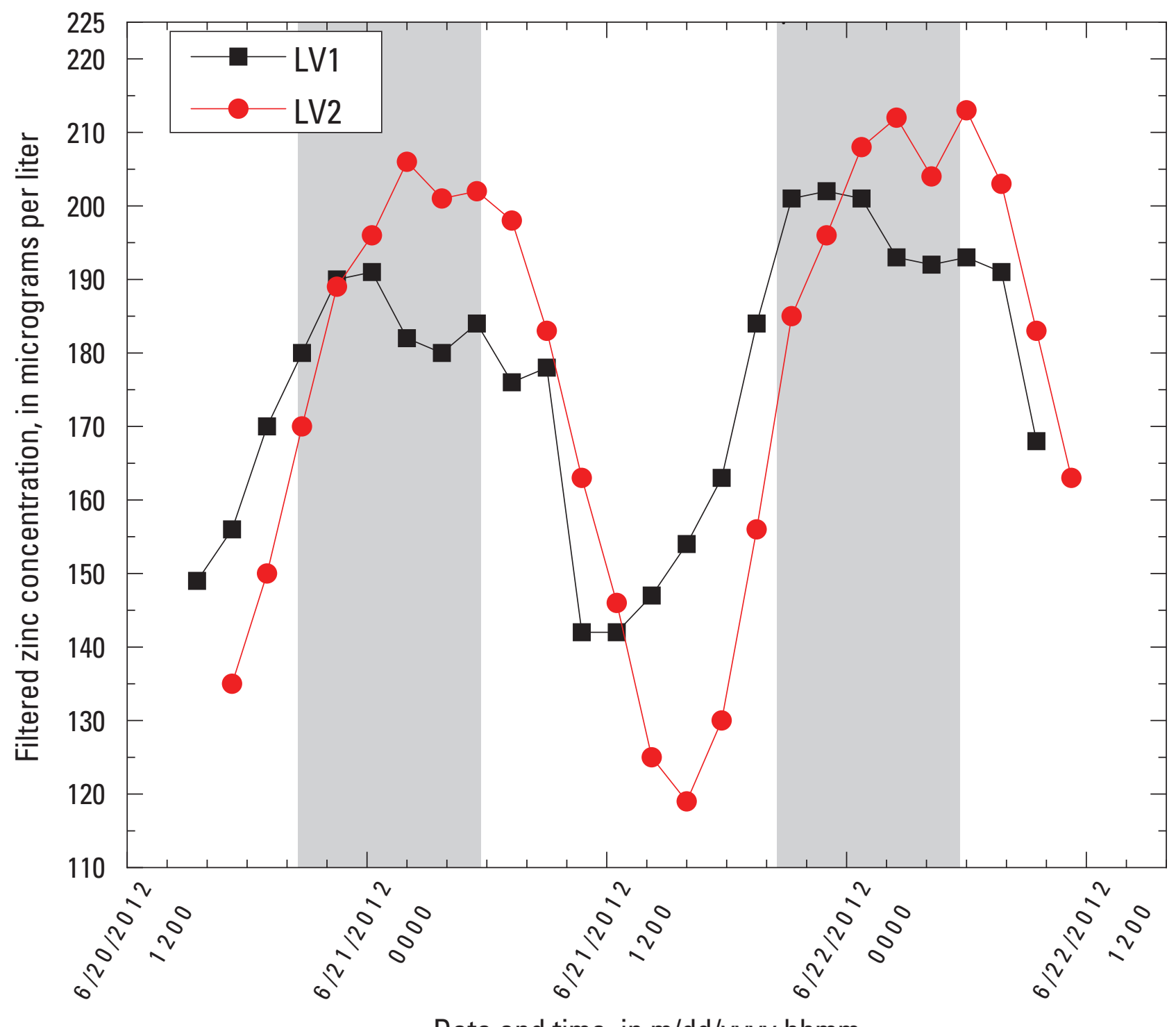

Date and time, in $\mathrm{m} / \mathrm{dd} / \mathrm{yyyy}$ hhmm

Figure 8. Graph showing fluctuation in zinc concentrations in filtered, acidified samples collected using automatic sampling devices at sites LV1 and LV2 in Leavenworth Creek, Colorado, June 20-22, 2012. Shaded areas represent nighttime (sunrise and sunset times are from Sunrise Sunset, 2019a).

\section{Diel Cycling}

During August, monitoring at two stream sites, T2, and $\mathrm{T} 3$, and one inflow site, LC1203-L, for diel variations in temperature, $\mathrm{pH}$, specific conductance, and dissolved oxygen (site T3 only), indicated some similar and some different patterns to those measured in June 2012. As expected, like June, maximum temperatures occurred midday, and minimum temperatures occurred around sunrise for all three sites (fig. 9A-C). Variations in $\mathrm{pH}$ were somewhat different than in June (fig. 9D-F). At site T2, pH showed a mostly steady pattern with maximum values occurring midday generally coincident with maximum temperature, and minimum values occurring during the nighttime but not necessarily coincident with minimum temperature (fig. 9A and D). The amplitude of the $\mathrm{pH}$ fluctuations was approximately $0.2 \mathrm{pH}$ unit. At site T3, the diel pattern in $\mathrm{pH}$ is somewhat muted, having an amplitude of only approximately $0.1 \mathrm{pH}$ unit, and is somewhat garbled on August 28 (fig. 9E). Field notes indicated this sonde may have been in very shallow water, and it is possible that on August 28 it was not entirely submerged. At site LC1203-L, which is not a stream site but a seep coming out of the leftbank wetland area and carrying some of the inflow from the Wilcox Tunnel and Waldorf seeps, $\mathrm{pH}$ showed gradually increasing values with diel variation of maximum midday and minimum nighttime values overprinted on this pattern (fig. 9F). 

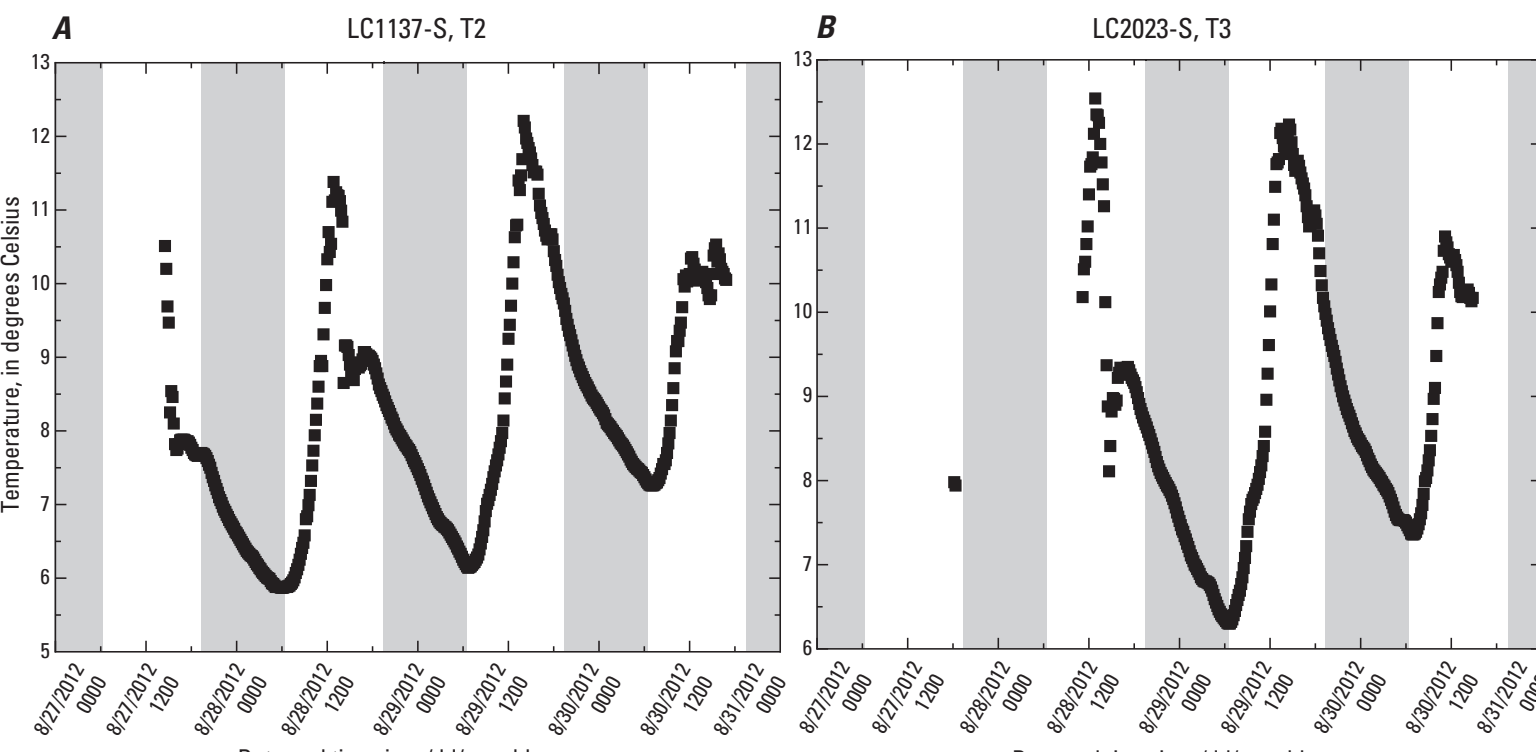

C

LC1203-L

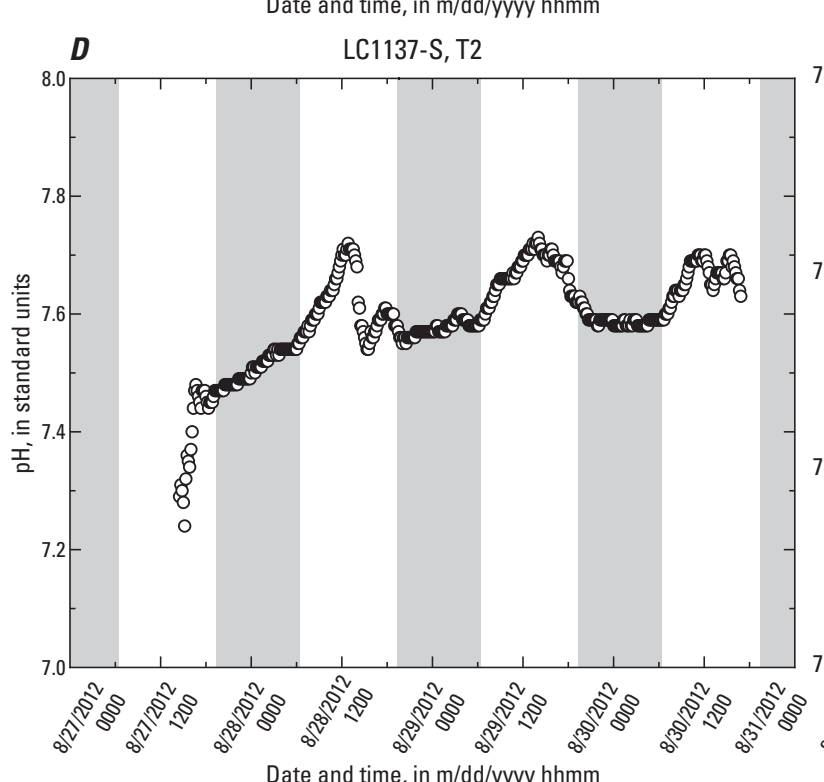
LC2023-S, T3

Date and time, in $\mathrm{m} / \mathrm{dd} / \mathrm{yyyy}$ hhmm

LC1203-L

Figure 9. Graphs showing variation of $A$, temperature at $\mathrm{LC} 1137-\mathrm{S}, \mathrm{T} 2$, (T2); $B$, temperature at LC2023-S, T3 (T3); $C$, temperature at LC1203-L; $D$, pH at T2; $E$, pH at T3; $F$, pH at LC1203-L; G, specific conductance at T2; $H$, specific conductance at T3; I, specific conductance at LC1203-L; J, stream discharge at U.S. Geological Survey station 06714800 (U.S. Geological Survey, 2019b); and $K$, dissolved oxygen at T3, during August 27-30, 2012. Shaded areas represent nighttime (sunrise and sunset times are from Sunrise Sunset, 2019b).

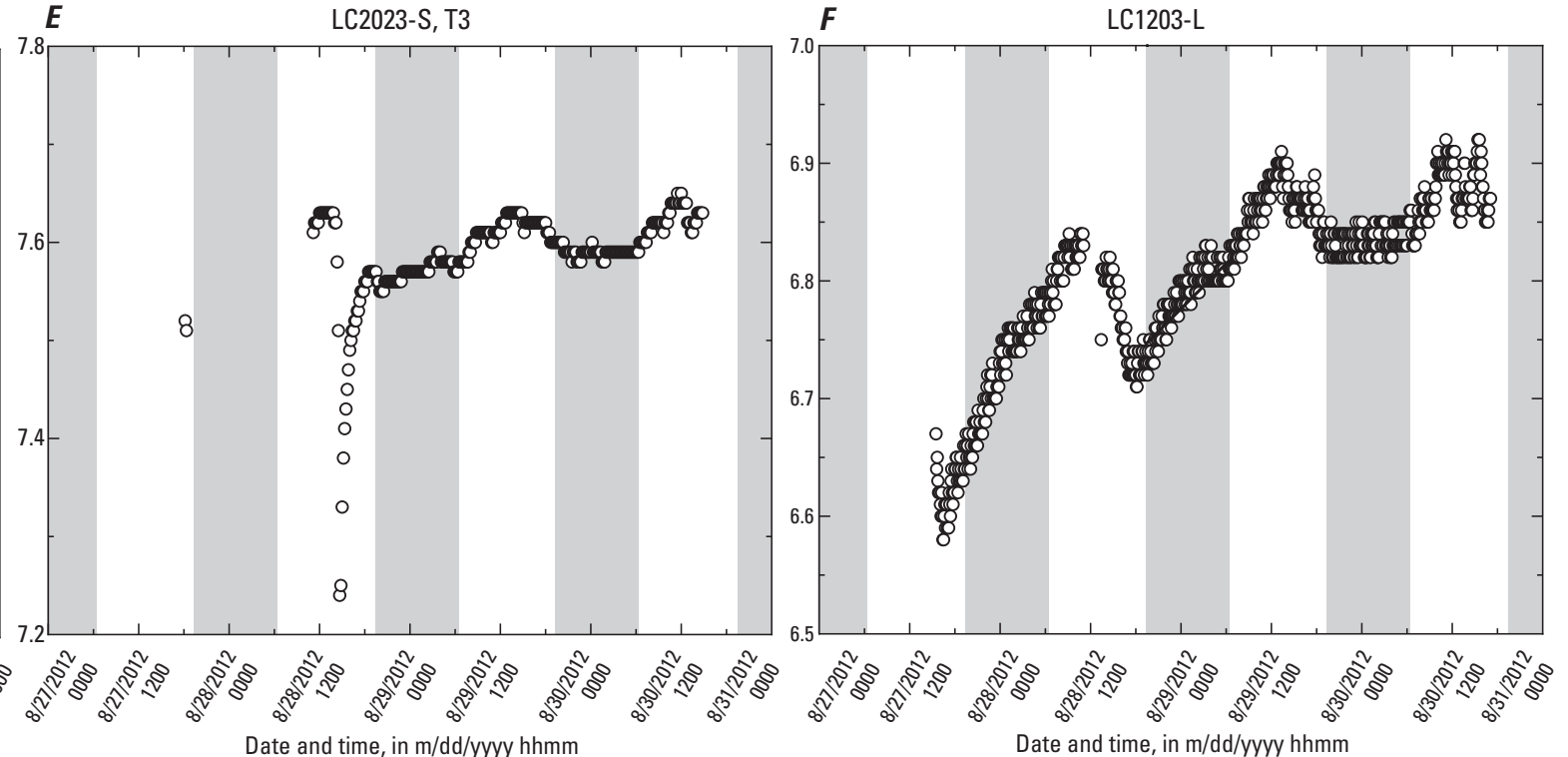



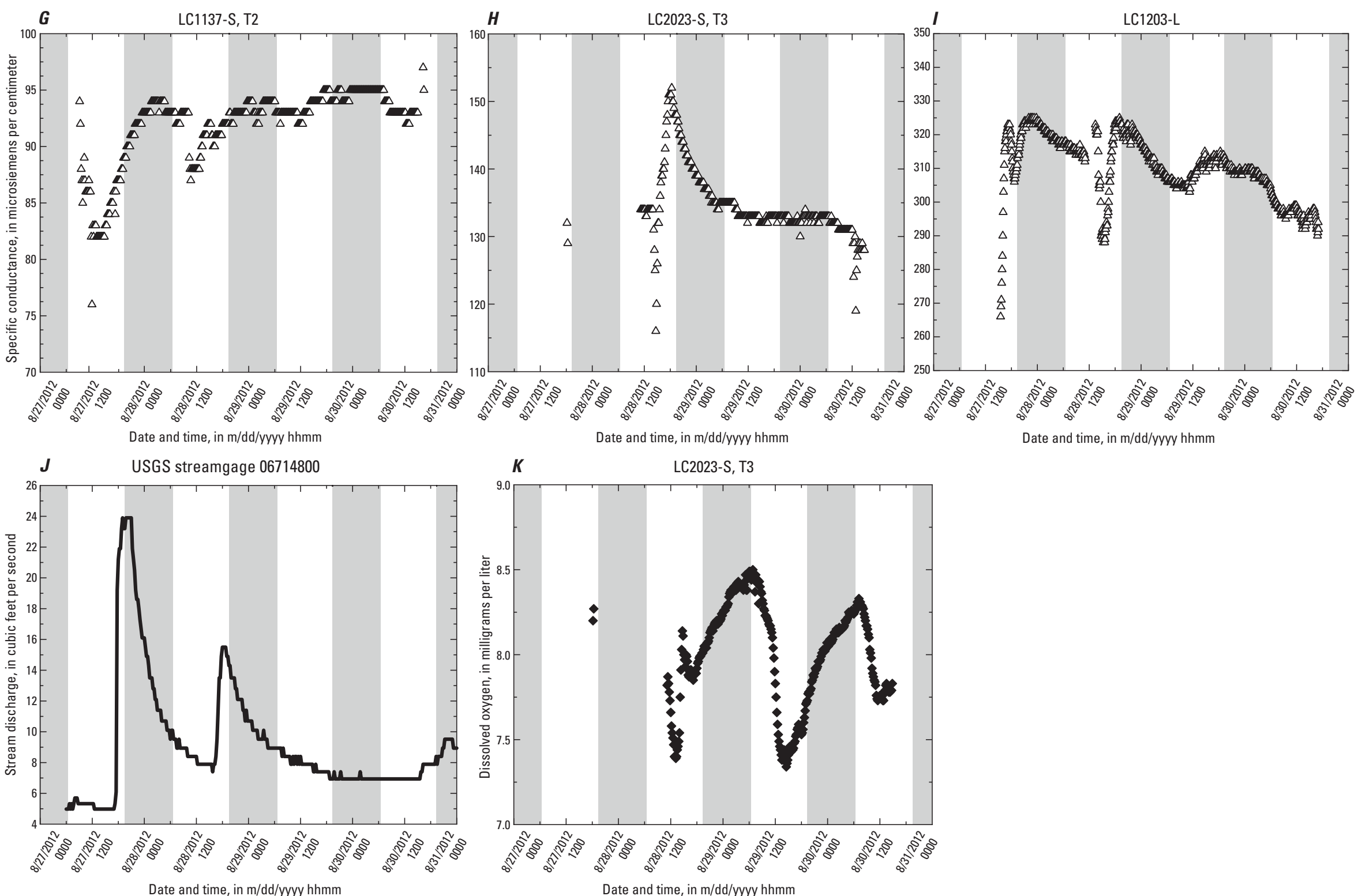

Date and time, in $\mathrm{m} / \mathrm{dd} / \mathrm{yyyy}$ hhmm

Date and time, in $\mathrm{m} / \mathrm{dd} / \mathrm{yyyy}$ hhmm

Date and time, in $\mathrm{m} / \mathrm{dd} / \mathrm{yyyy}$ hhmm

Figure 9. Graphs showing variation of $A$, temperature at $\mathrm{LC} 1137-\mathrm{S}$, T2, (T2); $B$, temperature at LC2023-S, T3 (T3); $C$, temperature at site field ID LC1203-L; $D$, pH at T2; $E$, $\mathrm{pH}$ at T3; F, pH at LC1203-L; G, specific conductance at T2; H, specific conductance at T3; I, specific conductance at LC1203-L; J, stream discharge at U.S. Geological Survey station 06714800 (U.S. Geological Survey, 2019b); and K, dissolved oxygen at T3, during August 27-30, 2012. Shaded areas represent nighttime (sunrise and sunset times are from Sunrise Sunset, 2019b).-Continued 
Diel variance of specific conductance was not presented for June 2012 but shows some interesting differences among sites (fig. 9G, H, I). At the upstream-most site, T2, specific conductance has a slight diel pattern with maximum values occurring during nighttime and minimum values occurring during midday, particularly on August 27 and 28 (fig. 9G). These fluctuations may be related to variation in stream discharge (fig. 9 J ). Storms late in the day on August 27 and 28 caused stream discharge to increase by up to a factor of approximately 4 (fig. 9J). Increasing specific conductance during nighttime at site T2 could be a result of decreased dilution as the storm hydrograph fell. Site T3 shows a completely different pattern with maximum values occurring just before sunset on August 28 and decreasing gradually through the next 24 hours (fig. 9H). Site LC1203-L shows a different pattern with maximum specific conductance values occurring generally right after sunset and minimum values occurring midday (fig. 9l). Patterns at T3 and LC1203-L (fig. 9H, I) somewhat parallel the storm hydrographs (fig. 9J ) indicating potential flushing of solute during storms at these sites. Dissolved oxygen patterns at T3 show strong diel variation with maximum values at dawn and minimum values at midday, coincident with maximum temperature at the site (fig. 9B, K). The dissolved oxygen patterns on August 28 are somewhat garbled like the other properties at the site indicating some potential problems with the sonde on that day (fig. 9B, E, H, K).

Diel variations in some trace elements, but not major elements, are apparent through patterns seen in ISCO samples collected August 28 through 30. Calcium concentrations, which are not expected to be affected by diel cycling, show generally increasing concentrations at site T2 (fig. 10A) and generally constant concentrations at site T3 (fig. 10B). These patterns do not show diel variation and generally parallel the patterns in specific conductance which increased at T2 from August 28 through 30 (fig. 9G) and was mostly constant at site T3 from August 29 through 30 (fig. 9H). In contrast, uranium and zinc concentrations at the sites show opposite diel variation (fig. 10C, D, E, F). This pattern indicates that uranium is likely present as an oxyanion, potentially as a calcium uranyl carbonate complex, such as indicated by speciation calculations for $\mathrm{pH}$ values greater than approximately 7.5 presented in Campbell and others (2015, fig. 1). The pattern at T3 is not as evident, and unfortunately, a longer record at the site may have clarified the issue. One low-biased uranium outlier on August 29 at T3 is likely from analytical variability. Uranium is not a contaminant of concern at this site but was the only potentially anionic constituent having concentrations greater than the reporting level and is shown as an example of diel cycling of anionic constituents.

More importantly, zinc, which is a major concern for this study, shows maximum concentrations during nighttime and minimum concentrations midday for August 29 through 30 at sites T2 (fig. 10E) and T3 (fig. 10F). The pattern from August 28 through 29 at site T2 may be difficult to discern because it is combined with the pattern of increasing specific conductance during that time and lower $\mathrm{pH}$ and temperature than from August 29 to 30 (fig. 9A, C), which all combine to increase zinc concentrations during the nighttime of August 28 through 29 compared to August 29 through 30. One high-biased outlier for zinc concentration (not shown on the graph but indicated by the lines between two adjacent samples; fig. 10F) just after sunset on August 29 at T3 is the same sample that showed a low bias in uranium concentration (fig. 10D). These outliers generally indicate a potential issue with analytical variability in this sample. Overall, the maximum diel variation in zinc concentrations at site T2 was from $14.3 \mu \mathrm{g} / \mathrm{L}$ at 1400 hours on August 29 to $19.4 \mu \mathrm{g} / \mathrm{L}$ at 0500 hours on August 30 (fig. 10E), an increase of approximately 33 percent. At site $\mathrm{T} 3$, the maximum zinc variation was from $145 \mu \mathrm{g} / \mathrm{L}$ at 1320 hours on August 29 to $182 \mu \mathrm{g} / \mathrm{L}$ at 0620 hours on August 30, an increase of 26 percent (fig. 10F). Note that synoptic sampling at 1200 hours on August 30 took place near when zinc concentrations in the stream were at minimum values. At this time, approximately 36 hours after storms on August 27 and 28, stream discharge returned to steady conditions (fig. 10G).

\section{Tracer Dilution Stream Discharge Calculations}

A known mass flow of sodium bromide was added to the stream at the top of the reach to estimate stream discharge at all stream-sampling sites using tracer dilution. Four velocitymeter measurements were collected for comparison. Over the study reach, bromide decreased by dilution from approximately 3.5 to 1.5 milligrams per liter (fig. 11A) indicating increasing stream discharge (fig. 11B). At four sites (indicated by arrows on fig. 11), the measured bromide concentration was adjusted for either of two reasons. First, bromide concentration increased in the downstream direction, likely because of minor analytical variability. In these cases, the bromide concentration at the site with the elevated value was replaced with a value interpolated using bromide concentrations at sites immediately upstream and downstream. Second, measured bromide concentration was, in one case at LC1693-S, lower than that at both the upstream and downstream sites, and an interpolated bromide concentration was used to calculate stream discharge at that site.

The profile of bromide-calculated stream discharge and velocity-meter measurements indicates increasing stream discharge over the study reach from approximately 1.8 to approximately 4.3 cubic feet per second, particularly from approximately 1,000 to $1,250 \mathrm{~m}$ where the Wilcox Tunnel inflows join the stream. Stream discharge more gradually increases from approximately 1,250 to 2,000 m. There is also possible stream discharge loss in the downstream-most reaches of the study area (fig. 11B), from approximately 1,800 $\mathrm{m}$ to the end of the study reach where bromide-calculated stream discharge is greater than velocity-meter stream discharge. In this area of the study reach, anastomosing channels were observed-areas where stream discharge was visibly leaving the main channel. For the purposes of the loading analysis, the stream discharge calculated from bromide dilution is used at all stream sites and represents all water flowing in multiple channels, and some perhaps lost to shallow groundwater flow at the end of the study reach. 
$\boldsymbol{A}$

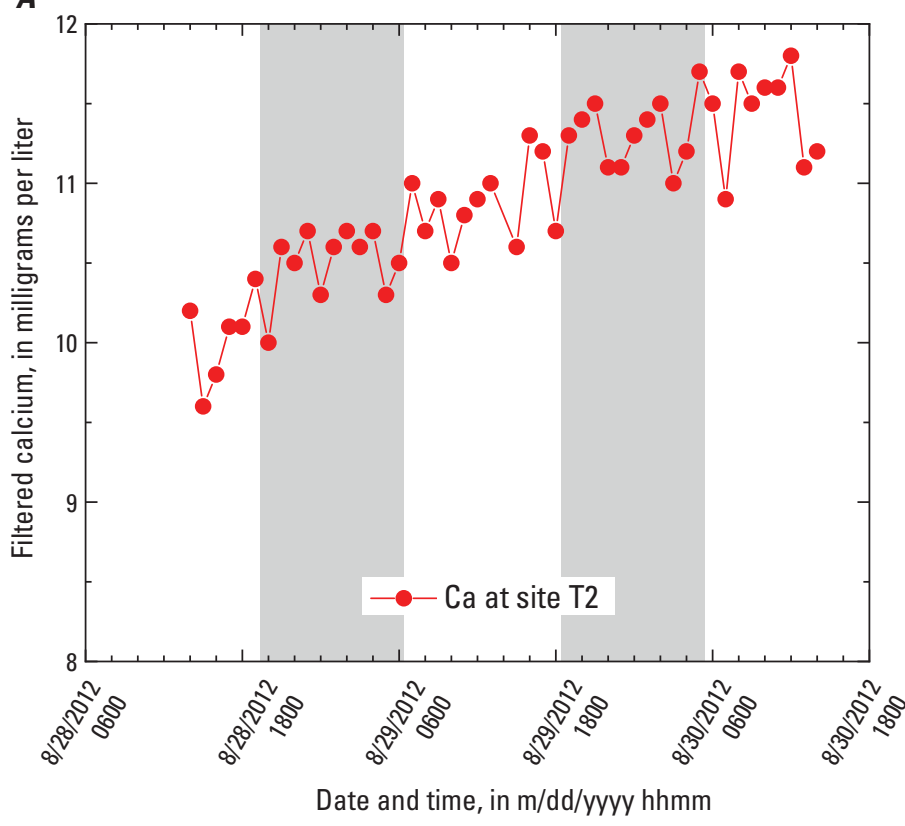

C

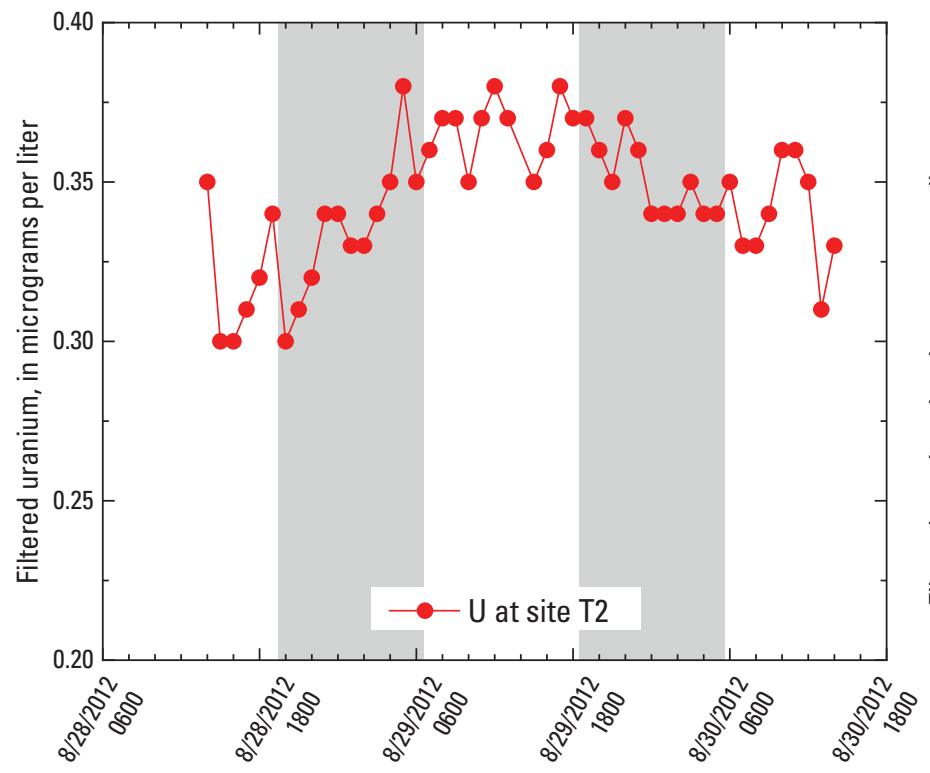

Date and time, in $\mathrm{m} / \mathrm{dd} / \mathrm{yyyy}$ hhmm
B

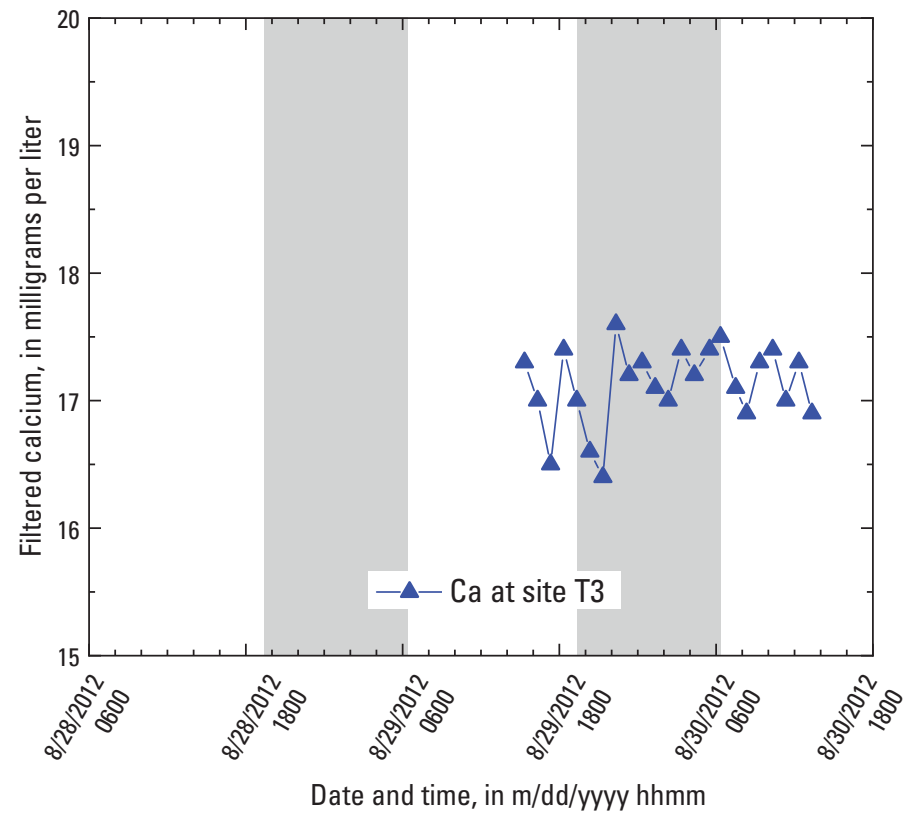

D

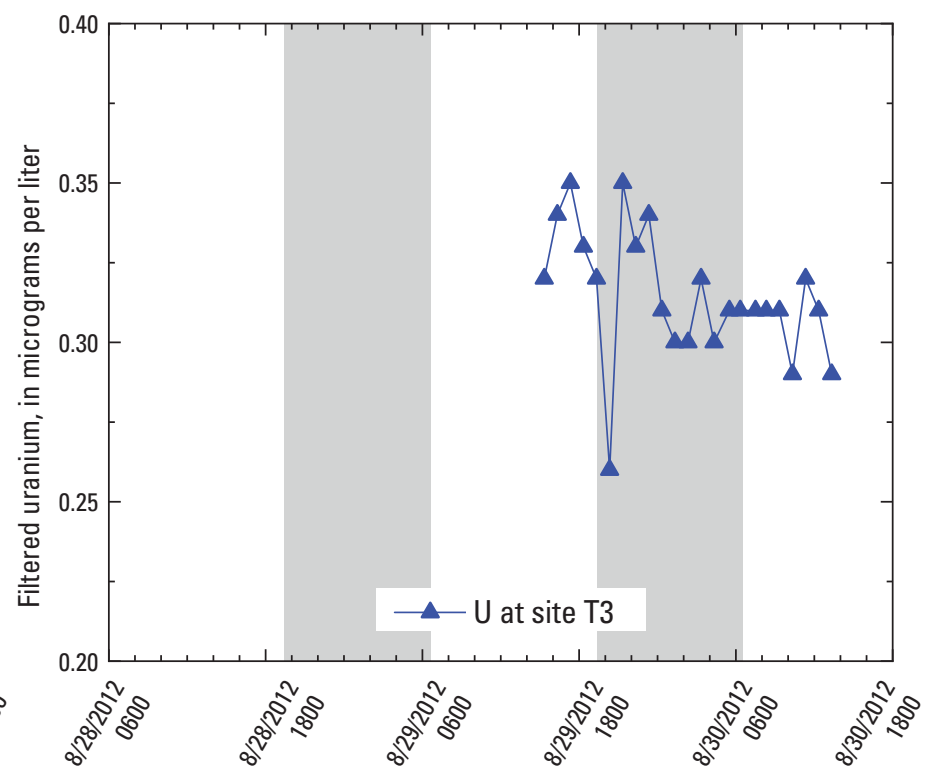

Date and time, in $\mathrm{m} / \mathrm{dd} / \mathrm{yyyy}$ hhmm

Figure 10. Graphs showing variation in $A$, filtered calcium (Ca) concentrations at LC1137-S, T2, (T2); $B$, filtered Ca concentrations at LC2023-S, T3 (T3); $C$, filtered uranium (U) concentrations at T2: $D$, filtered U concentrations at T3; $E$, filtered zinc (Zn) concentrations at T2; F, filtered Zn concentrations at T3; and G, stream discharge at U.S. Geological Survey station 06714800 (U.S. Geological Survey, 2019b), Leavenworth Creek, Colorado, at the mouth near Georgetown, from August 28 to 30, 2012. Shaded areas represent nighttime (sunrise and sunset times from Sunrise Sunset, 2019b). 
$\boldsymbol{E}$

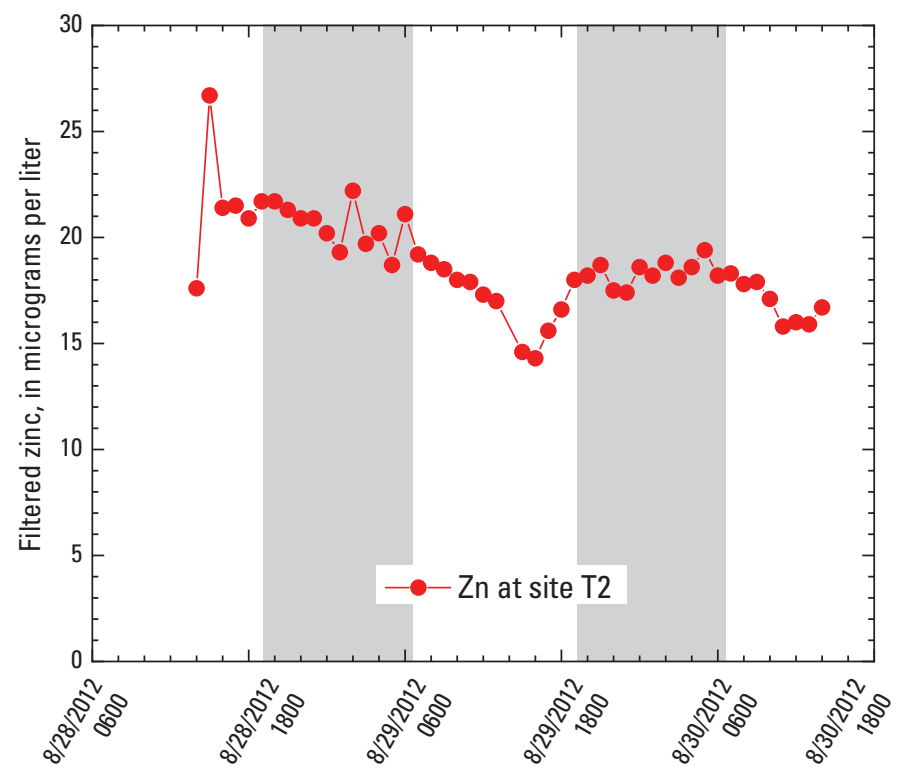

Date and time, in $\mathrm{m} / \mathrm{dd} / \mathrm{yyyy}$ hhmm

$\boldsymbol{G}$

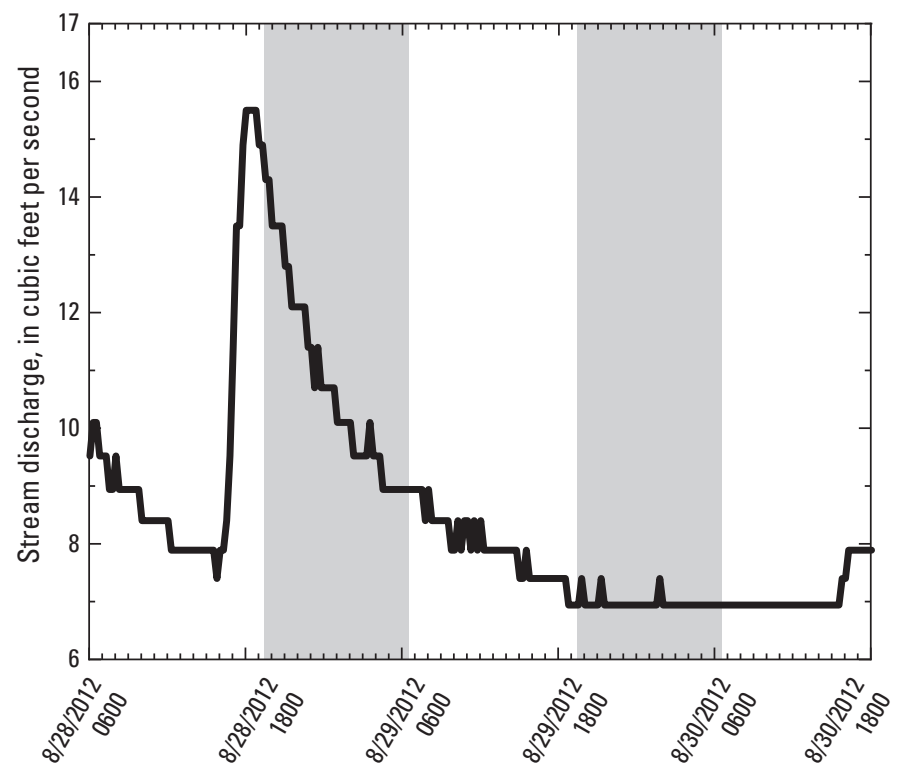

Date and time, in $\mathrm{m} / \mathrm{dd} / \mathrm{yyyy}$ hhmm
$\boldsymbol{F}$

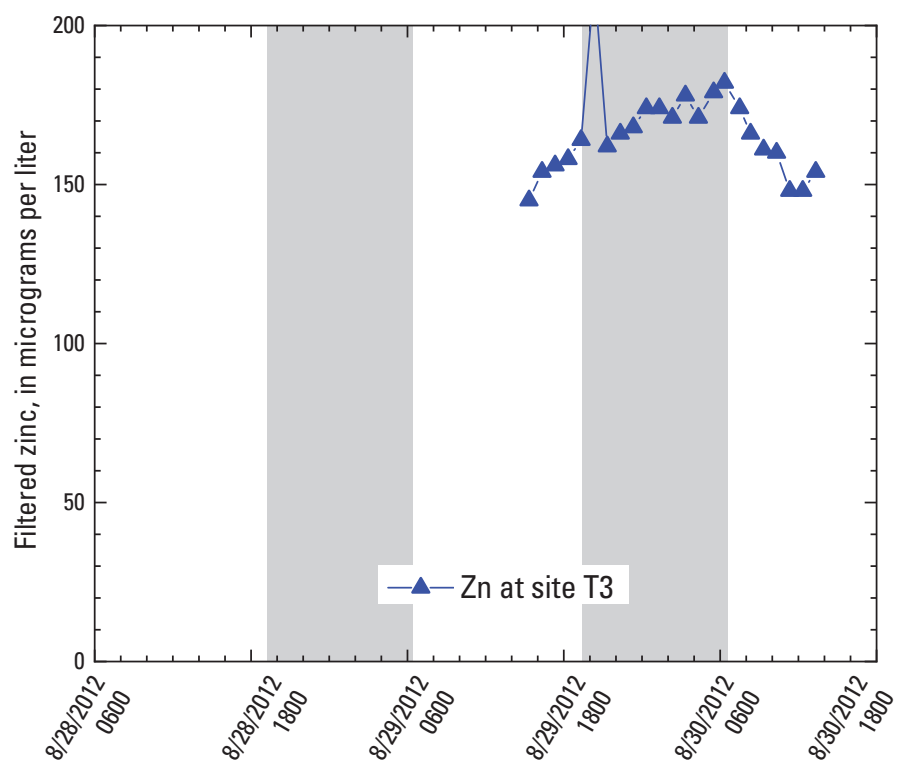

Date and time, in $\mathrm{m} / \mathrm{dd} / \mathrm{yyyy}$ hhmm 
A

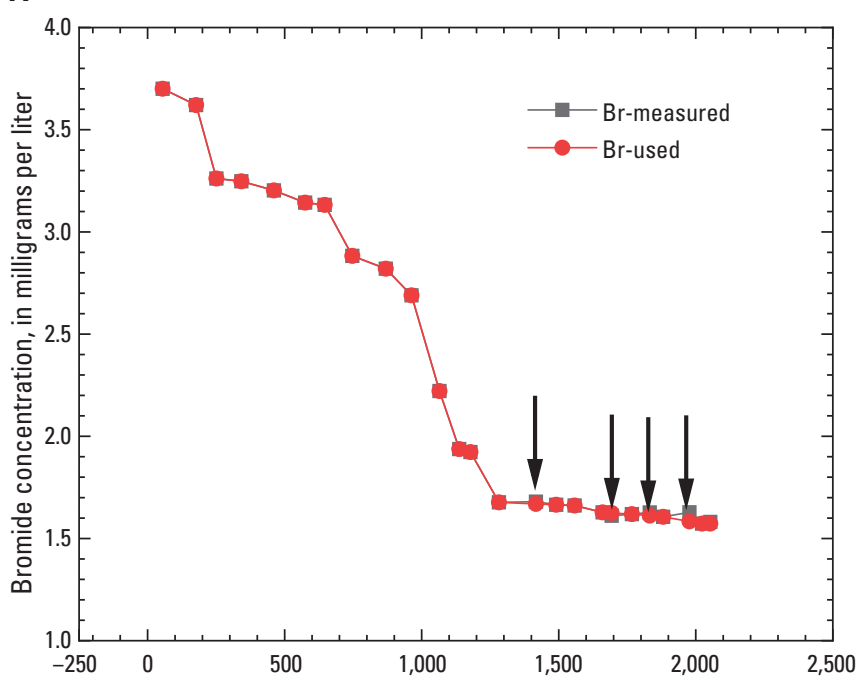

$B$

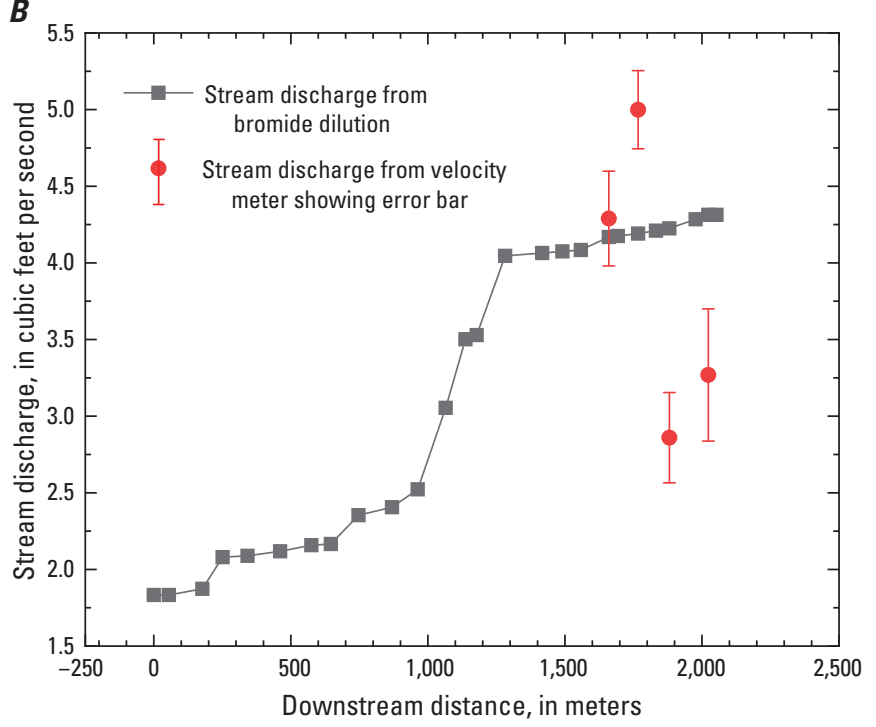

Figure 11. Graphs showing $A$, variation in bromide $(\mathrm{Br})$ concentrations measured and $\mathrm{Br}$ concentrations used to calculate stream discharge in all stream samples collected along Leavenworth Creek, Colorado, on August 30, 2012; and B, stream discharge calculated from $\mathrm{Br}$ concentrations and measured using velocity meters. Four arrows in $A$ indicate where $\mathrm{Br}$ concentration used to calculate stream discharge was slightly adjusted from $\mathrm{Br}$ concentration measured in stream samples by interpolating concentrations at upstream and downstream sites.

\section{Instantaneous Synoptic Sampling and Stream Profiles of Water Quality}

Stream profiles of $\mathrm{pH}$, specific conductance, filtered zinc, and filtered copper concentrations were examined to understand variations in water quality in Leavenworth Creek during synoptic sampling. The $\mathrm{pH}$ data from the synoptic sampling (fig. 12) illustrates several points: (1) $\mathrm{pH}$ is greater than 7 in stream samples for the length of the study reach; (2) pH of left-bank inflows is less than $\mathrm{pH}$ of right-bank inflows; (3) stream $\mathrm{pH}$ values are more similar to right-bank than left-bank inflows; (4) left-bank inflow $\mathrm{pH}$ values are markedly lower downstream from 1,000 $\mathrm{m}$, in reaches containing the Wilcox Tunnel inflow, the seeps from the Waldorf Mine tailings piles (Waldorf seeps), and the left-bank dispersed tailings; and (5) $\mathrm{pH}$ in hyporheic sniffers installed approximately 20-23 cm deep into the streambed was similar to the stream. This information is consistent with water levels in the sniffers, which were slightly lower than water levels in the stream indicating the stream was recharging the hyporheic zone in these areas, despite the generally increasing stream discharge over this reach (fig. 11B).

Specific conductance data from synoptic sampling illustrates several points (fig. 13): (1) specific conductance in stream samples increased moving downstream near inflows from the Vidler Tunnel (LC689-L) and Wilcox Tunnel and Waldorf seep inflows (LC1203-L and LC1204-L); (2) specific conductance of left-bank inflows upstream from $1,000 \mathrm{~m}$ is generally less than specific conductance in the stream, whereas specific conductance of left-bank inflows was greater than stream values from $1,000 \mathrm{~m}$ downstream to the end of the study reach (with two exceptions); (3) right-bank inflow samples show less variation in specific conductance than leftbank inflows and are mostly greater than stream specific conductance; (4) the greatest specific conductance values are in the Wilcox Tunnel and Waldorf seep samples; and (5) specific conductance measured from hyporheic sniffers was similar to the stream.

The stream profile of zinc concentrations in filtered samples from the synoptic sampling has several noteworthy features (fig.14): (1) zinc concentrations in filtered stream samples increase in the downstream direction beginning at approximately $800 \mathrm{~m}$ (concentrations were below reporting levels upstream from this point), downstream from inflow carrying Vidler Tunnel water to the stream (LC689-L) and near zinc-rich left-bank inflows; (2) zinc concentrations increase again abruptly at approximately $1,250 \mathrm{~m}$, downstream from the Wilcox Tunnel and Waldorf seep inflows (LC1203-L and LC1204-L); (3) zinc concentrations distinctly increase again just downstream from the left-bank inflow, LC1843-L (at 1,843 m); (4) samples of left-bank inflows have lower filtered zinc concentrations upstream from $1,000 \mathrm{~m}$ than downstream and are generally greater than stream values except at two upstream inflows and at the most downstream inflow; (5) concentrations of filtered zinc are generally greater in almost all left-bank than right-bank inflow samples; (6) right-bank inflow samples show less variation in filtered zinc concentration than left-bank inflows and are mostly less than stream filtered zinc concentrations; (7) the greatest filtered zinc concentrations are in the Waldorf seep samples, the Wilcox Tunnel sample, and left-bank inflows sampled along the dispersed tailings reach; and (8) zinc concentrations in hyporheic sniffers were similar to those in the stream. 


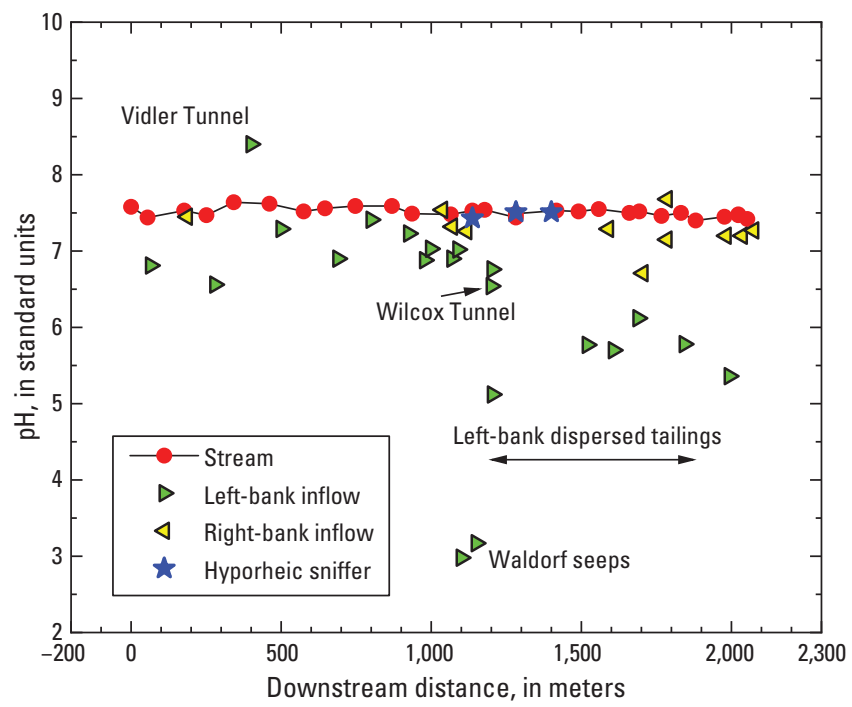

Figure 12. Graph showing stream profile of $\mathrm{pH}$ values measured in samples from the stream, left- and right-bank inflows, hyporheic sniffers, Vidler and Wilcox Tunnels, and Waldorf seeps.

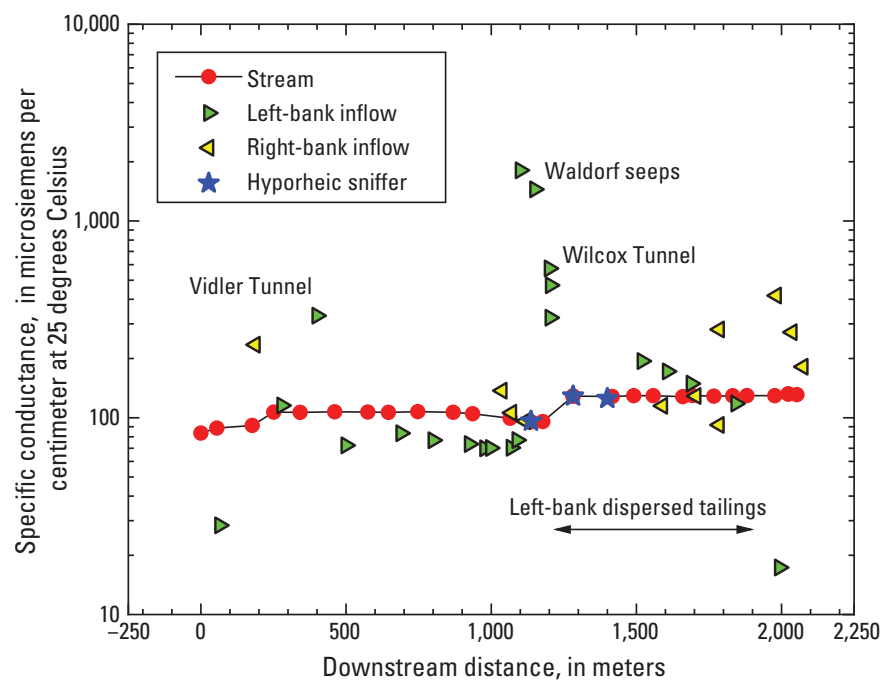

Figure 13. Graph showing stream profile of specific conductance in microsiemens per centimeter at 25 degrees Celsius measured in samples from the stream, left- and right-bank inflows, hyporheic sniffers, Vidler and Wilcox Tunnels, and Waldorf seeps.

The stream profile of copper concentrations in filtered samples from the synoptic-sampling event illustrates several points (fig. 15): (1) copper concentrations in filtered stream samples show less of a pronounced downstream increase than zinc concentrations; (2) there are clear increases in stream concentrations both at the Wilcox Tunnel/Waldorf seep inflow locations (LC1203-L and LC1204-L) and at the inflow LC1843-L; (3) samples of left-bank inflows have

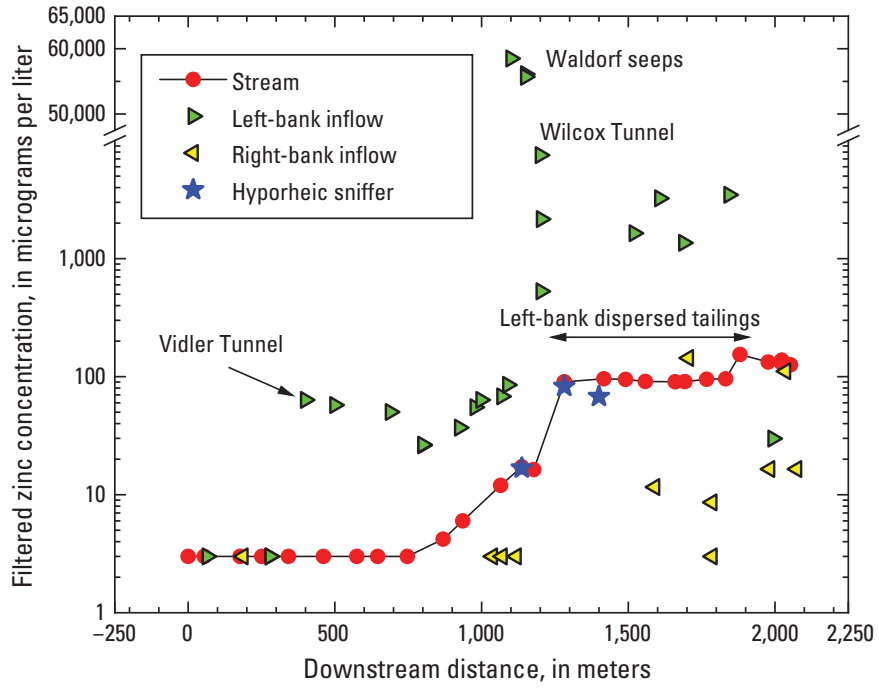

Figure 14. Graph showing stream profile of filtered zinc concentrations in micrograms per liter in samples from the stream, left- and right-bank inflows, hyporheic sniffers, Vidler and Wilcox Tunnels, and Waldorf seeps. Filtered zinc concentrations were less than reporting level from the top of the study reach through site LC747-S, located 747 meters downstream from the injection site.

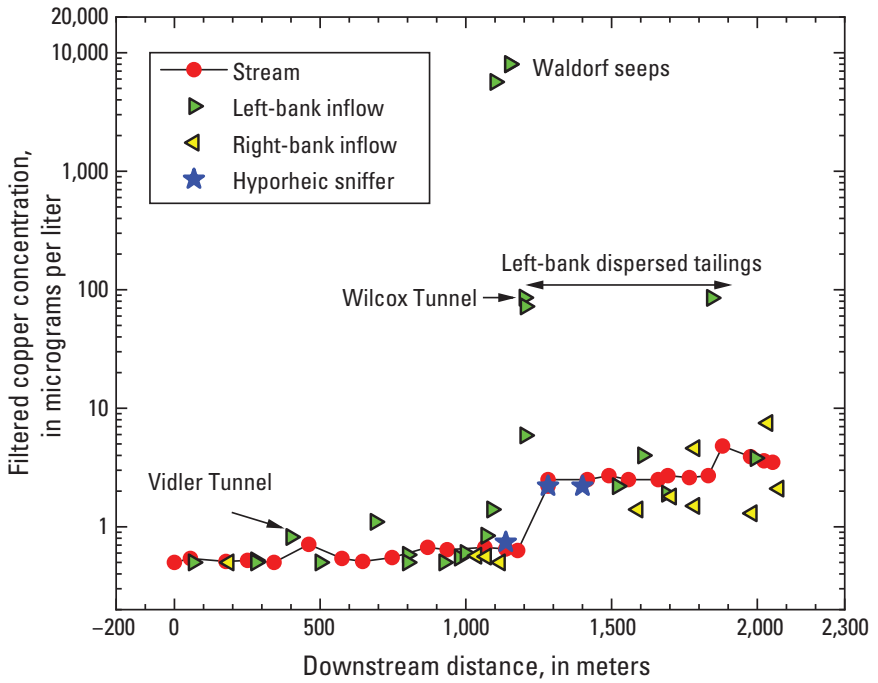

Figure 15. Graph showing stream profile of filtered copper concentrations in micrograms per liter in samples from the stream, left- and right-bank inflows, hyporheic sniffers, Vidler and Wilcox Tunnels, and Waldorf seeps.

lower filtered copper concentrations upstream from 1,000 m than downstream and are generally only greater than stream values in samples from the Waldorf seeps, the Wilcox Tunnel inflow, and a few samples collected from the dispersed-tailings reach; (4) right-bank inflow samples show lower variation in filtered copper concentrations than left-bank inflows and are similar to stream filtered copper concentrations all along the 
study reach; (5) the greatest filtered copper concentrations are in the Waldorf seep samples, the Wilcox Tunnel sample, and left-bank inflows sampled along the dispersed tailings reach; (6) filtered copper concentrations in hyporheic sniffers were similar to those in the stream; and (7) a distinct difference between the stream profiles of filtered copper and zinc concentrations is that, in the 500-1,000 m reach, filtered zinc concentrations in left-bank inflows are greater than concentrations in the stream and likely cause the gradual increase in filtered zinc concentrations observed in this reach. No similar strong pattern is observed for copper in filtered stream and inflow samples in the same reach, though a few, but not all, left-bank inflow samples have copper concentrations greater than the stream. The low instream copper concentrations between sites $\mathrm{T} 1$ (at $342 \mathrm{~m}$ ) and T2 (at 1,137 m) support the interpretation of contamination in the T1 ISCO samples.

\section{Metal-Mass Loading Stream Profiles}

An instantaneous mass load is the product of concentration and stream discharge in mass per time, herein reported in kilograms per day and grams per day. Mass loads are definitive for locating sources of metal to streams because, in a stream that gains flow, mass load is conserved. Locations where load increases indicate sources of metal to the stream; locations where load decreases indicate metal removal from the water column by precipitation reactions or settling of metal-rich particulate to the streambed. The filtered zinc load profile (fig. 16) shows that the two greatest sources of filtered zinc to the stream are the left-bank inflows carrying input from both the Wilcox Tunnel and Waldorf seeps (LC1203-L and LC1204-L) and the stream reach containing a distinct leftbank inflow (LC1843-L, 1,843 m downstream from the bromide injection) that drains some of the area of the dispersed tailings. The zinc-load profile does not indicate much inflow from diffuse sources that would present as a ramping up of the load profile over several locations. Zinc loads decrease near the downstream end of the study reach indicating instream removal of zinc, or zinc attenuation, likely by precipitation of iron oxyhydroxide phases and sorption or coprecipitation of zinc with the iron precipitates (fig. 16).

Mass-load profiles for total (unfiltered) copper and lead (fig. 17A) show that the source locations that are important for zinc are also important for these metals. But the load profiles for these two metals also indicate that more diffuse sources for loads, or other surface inflows, are adding copper and lead to the stream both in the reach from approximately $800 \mathrm{~m}$ to the Wilcox Tunnel and Waldorf seep inflows (about 1,200 m) and near the left-bank dispersed tailings inflow (LC1843-L), from about 1,300 to $1,800 \mathrm{~m}$. However, the absolute mass of copper and lead (y-axis in grams per day, fig. 17A) is at least 10 times less than that of zinc (y-axis in tenths to whole kilograms per day; figs. 16 and 17B). Also, replicate samples shown at locations LC1282-S and LC2023-S show a small amount of variability in load. The sample in the copper load curve at LC1417-S is not shown because that sample was rejected after quality assurance/quality control evaluation. This sample had a concentration of $5.2 \mu \mathrm{g} / \mathrm{L}$ copper compared to $3.3 \mu \mathrm{g} / \mathrm{L}$ at the upstream site (LC1282-S) and $3.6 \mu \mathrm{g} / \mathrm{L}$ at the downstream site (LC1491-S). Filtered copper concentrations at this site showed no similar spike (fig. 15). The spike in total copper concentration could be the result of variability noted in the replicate or inclusion of streambed material stirred up during sampling in the sample bottle, leading to greater total copper concentrations. However, because this sample did not show a similar result for other analytes that might occur in streambed materials (aluminum and iron; lead and manganese, fig. 17A, B), this result is likely anomalous and is excluded from discussion. The value is retained in the NWIS database but is not publicly available because the associated data-quality indicator code is set to "reviewed and rejected."

Manganese load is of similar magnitude to zinc load but shows a slightly different pattern (fig. 17B). The manganese load begins to gradually increase from around $700 \mathrm{~m}$ to just downstream from the Wilcox Tunnel and Waldorf seep inflows (LC1203-L and LC1204-L). Manganese load is generally constant in the reach containing the dispersed tailings and shows a step increase in the reach containing the inflow that drains part of the left-bank dispersed tailings, LC1843-L, though of a lesser magnitude than the zinc increase. Thereafter, load decreases slightly or is constant to the end of the study reach.

Kimball and others (2002) introduced the concept of cumulative mass load, which is the running sum of positive increases in load moving downstream along a creek. Comparing the stream load measured at each stream segment

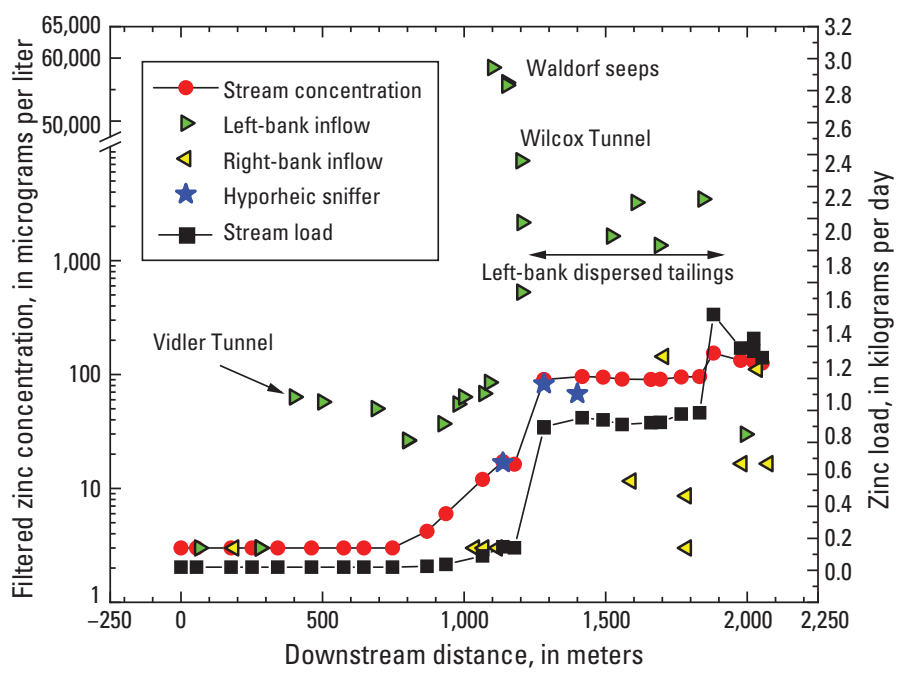

Figure 16. Graph showing stream profile of zinc concentrations in micrograms per liter in samples from the stream, left- and right-bank inflows, hyporheic sniffers, Vidler and Wilcox Tunnels, and Waldorf seeps from figure 14 and zinc load for the filtered stream samples. Filtered zinc concentrations were less than reporting level from the top of the study reach through site LC747-S located 747 meters downstream from the injection site. 

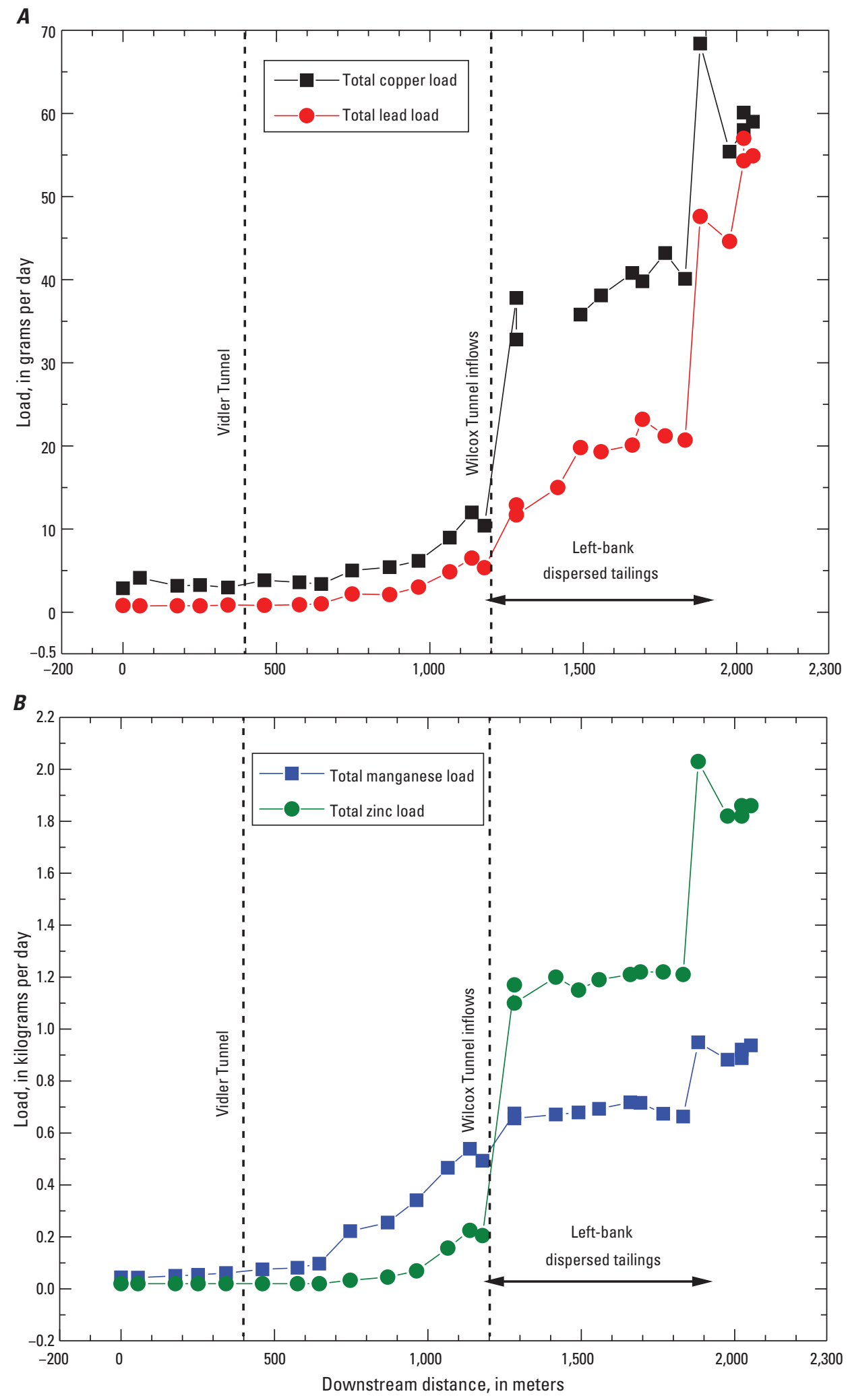

Figure 17. Graphs showing stream profiles of $A$, total (unfiltered) copper and lead loads, in grams per day, and $B$, total (unfiltered) manganese and zinc loads, in kilograms per day, in stream samples collected in Leavenworth Creek, Colorado, August 30, 2012. 
to cumulative mass load over the entire study reach indicates the proportional load in percent, or the relative importance of loading in each stream segment. This approach indicates that inflows to the stream from the Wilcox Tunnel and Waldorf seeps (LC1203-L and LC1204-L, at 1,203 $\mathrm{m}$ and 1,204 m, respectively) are the greatest source of zinc load to the stream (about 45 percent). The inflow at LC1843-L (at 1,843 m) is the greatest source of lead (about 45 percent) and manganese (about 25 percent) to the stream, and also supplies about 40 percent of the zinc (fig. 18). Copper load is almost equally divided (about 35 percent) between the two sources (fig. 18). In addition, in the stream reach from approximately 800 to $1,200 \mathrm{~m}$, copper, lead, and manganese loads show gradual increases likely attributed to the diffuse loading from groundwater and small distinct inflows in this zone. Zinc shows this pattern to a lesser degree near the downstream end of this reach $(1,000-1,200 \mathrm{~m})$. Similarly, in the reach containing dispersed tailings on the left bank from approximately 1,300 to $1,800 \mathrm{~m}$, copper, lead, and to a lesser extent manganese loads show gradual increases, likely attributed to diffuse loading from the dispersed tailings. The source of one large lead load increase near 2,000 m (figs. 17B and 18) is not known. Copper, zinc, and, to a lesser extent manganese, show some attenuation, or decrease in load, at the very end of the study reach (fig. 17A, B).
The absolute value of loads shown in all figures are minimum estimates because the instream synoptic samples were collected at 1200 hours near the time when minimum concentrations for positively charged elements in solution, including copper, zinc, lead, and manganese occurred in the stream (for example, zinc in figs. 8 and 10). In addition, stream discharge was also at minimum values at that time (fig. 10G). Diel sampling indicated that maximum zinc concentrations were between 26 and 33 percent greater than minimum concentrations. Daily loads of zinc, if based on measurement of maximum zinc concentrations before dawn, would be expected to be as much as 33 percent greater than those measured at 1200 hours on August 30, 2012. However, the relative proportion of loads from different sources would likely remain the same.

\section{Effects of Vidler Tunnel Discharge on Water Quality in Leavenworth Creek}

One of the objectives of this study was to assess the amount of instream loading from the Vidler Tunnel. Discharge out of Vidler Tunnel into Leavenworth Creek has two possible sources: (1) native flow from fractures and other water-bearing

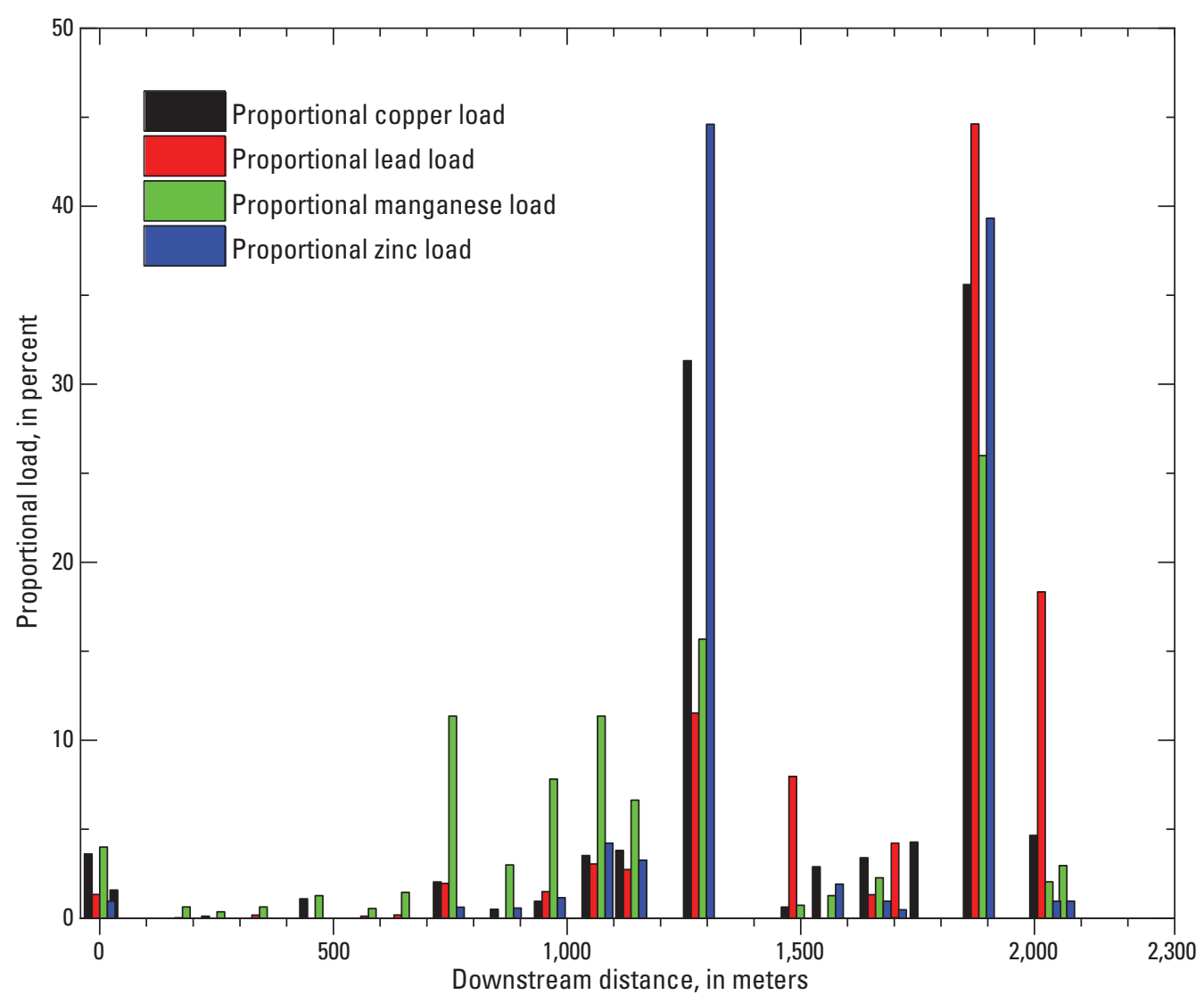

Figure 18. Graph showing proportional load with downstream distance for copper, lead, manganese, and zinc in stream samples collected in Leavenworth Creek, Colorado, August 30, 2012. 
zones that empty into the tunnel and (2) transmountain water imported from the Peru Creek watershed during active water diversion. All flow out of the Vidler Tunnel during the synopticsampling period (August 28-30, 2012) was native flow because the water diversion from Peru Creek into Leavenworth Creek was inactive. Stream profiles of metal loads (figs. 16 and 17) do not indicate a large contribution from the Vidler Tunnel to the stream (the Vidler Tunnel inflow enters the stream at the site LC689-L but graphs (figs. 12-16) show Vidler at about $400 \mathrm{~m}$ because that is the distance measured perpendicular to the stream where the tunnel is physically located and where Vidler Tunnel samples were collected). It is possible that some portions of the diffuse loading of copper, lead, manganese, and to a lesser extent zinc, observed from 800 to $1,000 \mathrm{~m}$ is from the Vidler Tunnel. During June 2012, the Forest Service and their partners conducted high-flow synoptic sampling when the Vidler Tunnel was sampled and transmountain diversion of water from the Peru Creek watershed was active (U.S. Forest Service, 2013a). Inflow from the Vidler Tunnel into Leavenworth Creek at that time increased zinc loads from about 0.07 to about 2.6 kilograms per day, a factor of approximately 37 times. In addition, the report noted that zinc loads measured at the mouths of the Vidler and Wilcox Tunnels were similar at about 3 kilograms per day. No similar magnitude load increase was noted from the Vidler Tunnel during the August 2012 synoptic-sampling event (figs. 16 and 18).

To further assess contributions of native versus imported Vidler Tunnel water on water quality in Leavenworth Creek, concentrations and loads of copper, lead, manganese, and zinc measured during the June 2012 sampling event were compared to those measured on August 28, 2012. High-flow concentrations in June 2012 (U.S. Forest Service, 2013a) at Vidler Tunnel outflow varied between 5 to almost 80 times greater than during low flow in August 2012 (table 5). (Note that figure 1 in U.S. Forest Service [2013a] indicates the Vidler Tunnel sampling location is at nearly the same location used in this study). Similarly, metal loads during June 2012 varied from more than 1,000 to almost 15,000 times the loads on August 28, 2012. These comparisons indicate that the combination of imported and native water at the Vidler Tunnel outflow during June 2012 contained substantially greater concentrations and metal load than native water flowing out of the tunnel August 28, 2012. It is unknown what contribution of the June outflow was native water. The native water contribution was likely more than what was measured in August 2012 because of snowmelt contributions to groundwater recharge, but the difference in native water contribution to Vidler Tunnel between June and August 2012 is not known.

Photographs further document potential effects of transmountain water diversion through the Vidler Tunnel on water quality in Leavenworth Creek. When water is not being imported, there is a very small amount of native water flowing from the tunnel (fig. 19A) versus when water is being imported (fig. 19B). When water is not being imported, there is little evidence of a mixing zone where the water from the Vidler Tunnel joins Leavenworth Creek (fig. 19C), compared to when water is being imported (fig. 19D). The white precipitate observed in the mixing zone is likely aluminum coming out of solution as lower $\mathrm{pH}$, metal-rich water from the Vidler Tunnel mixes with higher $\mathrm{pH}$ water in Leavenworth Creek and indicates that Vidler Tunnel water degrades water quality in Leavenworth Creek. Together, the loading and visual evidence indicate that transmountain diversion of water through Vidler Tunnel negatively affects the water quality in Leavenworth Creek. An additional evaluation of the effect of imported compared to native Vidler Tunnel water would be to compare loads at the upstream and downstream ends of Vidler Tunnel when water imports are active to quantify the amount of load from native flow that occurs during higher flow and what effect mineralization in the Vidler Tunnel has on metal loads. Such a comparison was not included in this study.

Table 5. Comparison of total (unfiltered) and filtered concentrations and loads of copper, lead, manganese, and zinc measured in samples collected at the Vidler Tunnel outflow in June and August 2012.

[High-flow data from U.S. Forest Service, 2013a]

\begin{tabular}{|c|c|c|c|c|c|c|}
\hline Constituent & $\begin{array}{l}\text { Concentration, in } \\
\text { micrograms per } \\
\text { liter at high flow } \\
\text { (June 2012) }\end{array}$ & $\begin{array}{l}\text { Load, in kilo- } \\
\text { grams per day } \\
\text { at high flow } \\
\text { (June 2012) }\end{array}$ & $\begin{array}{l}\text { Concentration, in } \\
\text { micrograms per } \\
\text { liter at low flow } \\
\text { (August 2012) }\end{array}$ & $\begin{array}{l}\text { Load, in kilo- } \\
\text { grams per day } \\
\text { at low flow } \\
\text { (August 2012) }\end{array}$ & $\begin{array}{l}\text { Concentration } \\
\text { ratio, high flow/ } \\
\text { low flow }\end{array}$ & $\begin{array}{l}\text { Load ratio, } \\
\text { high flow/low } \\
\text { flow }\end{array}$ \\
\hline Filtered copper & 35 & 0.26 & 0.82 & $2.9 \times 10^{-5}$ & 43 & 9,070 \\
\hline Total lead & 10 & 0.075 & 1.92 & $6.8 \times 10^{-5}$ & 5.2 & 1,110 \\
\hline Total manganese & 1,400 & 10.5 & 20.6 & $7.3 \times 10^{-4}$ & 68 & 14,400 \\
\hline Filtered manganese & 1,400 & 10.5 & 17.7 & $6.3 \times 10^{-4}$ & 79 & 16,800 \\
\hline Total zinc & 370 & 2.79 & 68.9 & 0.0024 & 5.4 & 1,140 \\
\hline Filtered zinc & 400 & 3.01 & 63.5 & 0.0023 & 6.3 & 1,340 \\
\hline
\end{tabular}



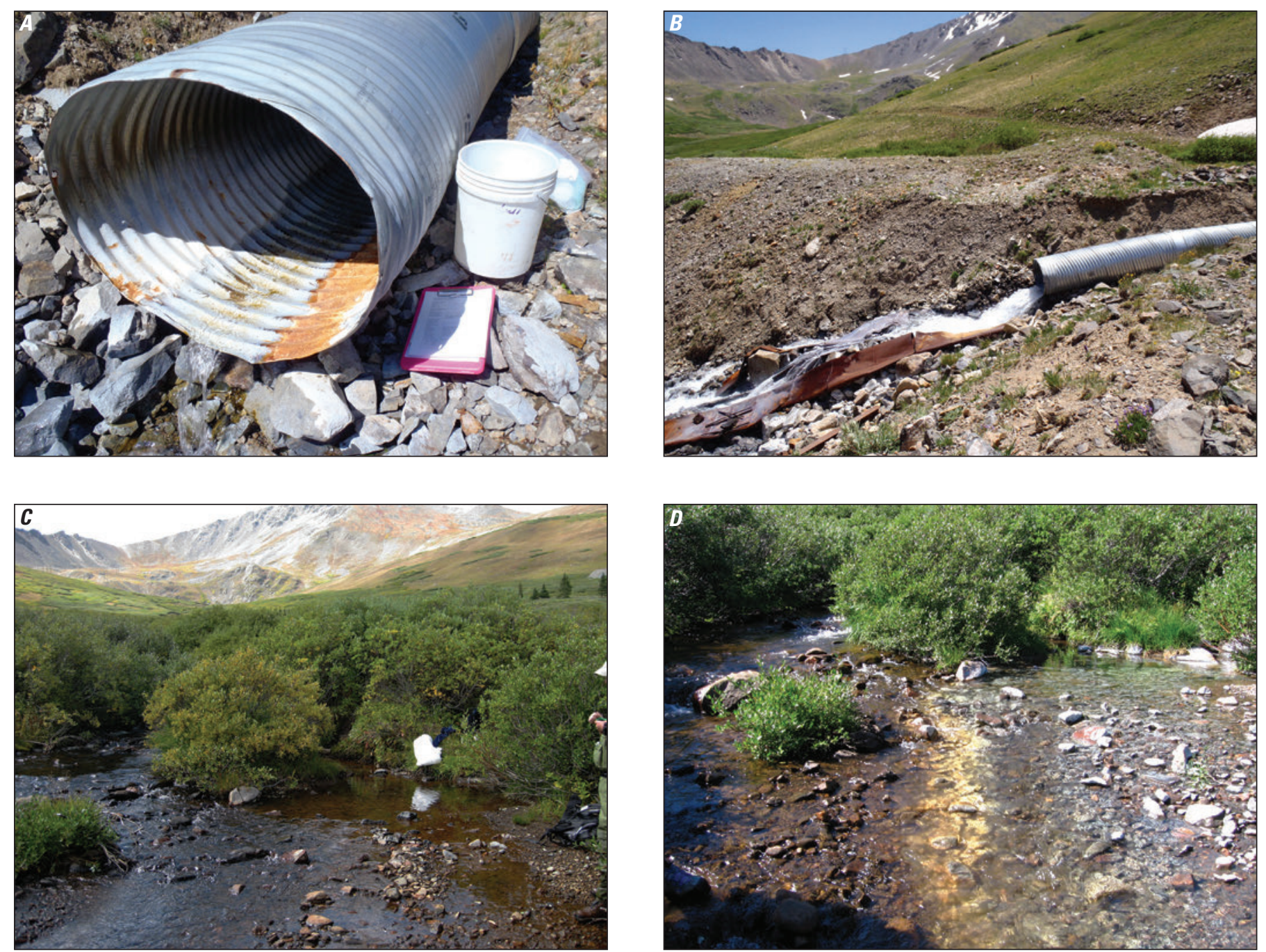

Figure 19. Photographs showing $A$, discharge from the Vidler Tunnel containing only native flow on August 29, 2012 (photograph by Katie Walton-Day, U.S. Geological Survey); B, discharge from the Vidler Tunnel containing native and imported flow on June 20, 2012, when Vidler Tunnel discharge from transmountain diversion of water was approximately 3 cubic feet per second (photograph by Katie Walton-Day, U.S. Geological Survey); $C$, site LC689-L where discharge from the Vidler Tunnel (containing only native water on this date) joins Leavenworth Creek on the right side of this photograph, taken on August 29, 2012 (photograph by Robert Runkel, U.S. Geological Survey); and $D$, site LC689-L where discharge from the Vidler Tunnel joins Leavenworth Creek, Colorado, on the right side of this photograph, taken on August 27, 2008, when the Vidler Tunnel discharge from transmountain diversion of water was 0.33 cubic feet per second (photograph by Richard Wanty, U.S. Geological Survey). Views in $C$ and $D$ are looking upstream. Vidler Tunnel stream-discharge data available from Colorado Division of Water Resources (2019).

\section{Summary}

Leavenworth Creek, a tributary of South Clear Creek and Clear Creek near Georgetown, Colorado, contains copper, lead, and zinc at concentrations close to or in excess of aquatic-life standards. These elevated metal concentrations likely result from mineralization and historical mining operations in the Argentine mining district located within the watershed. In the summer of 2012, the U.S. Geological Survey, in cooperation with the U.S. Department of Agriculture Forest Service and the
Colorado Division of Reclamation, Mining and Safety, collected data to (1) quantify the effects of diel cycling and perform synoptic sampling in a way to minimize those effects; (2) separate "point" or distinct single tributaries or sources of load from diffuse load sources along the study reach to aid remediation planning; and (3) quantify metal loading from transmountain diversion of water from Peru Creek through the Vidler Tunnel into Leavenworth Creek. The study included monitoring for diel cycles in June 2012 and diel and synoptic sampling in August 2012 along an approximately 2-kilometer stream reach. 
Initial sampling of Leavenworth Creek at two locations from June 20 to 22, 2012, indicated strong diel signals for temperature, dissolved oxygen, and $\mathrm{pH}$. Concentrations of zinc, cadmium, cobalt, manganese, and yttrium showed strong diel fluctuations at both sites with minimum concentrations during daytime and maximum concentrations during nighttime. Because of the diel cycles, during synoptic sampling, stream samples were all collected at precisely the same time, 1200 hours on August 30, 2012. Synoptic samples were collected at 26 stream and 35 inflow, tributary, mine waste seep, and mine tunnel sites from August 28 to 30, 2012.

Monitoring at two stream sites, T2 and T3, and one inflow site, LC1203-L, for diel variations in temperature, $\mathrm{pH}$, specific conductance, and dissolved oxygen (site T3 only) during August indicated patterns generally similar to those observed in June 2012. Uranium and zinc concentrations at sites T2 and T3 show opposite diel variation. Uranium is not a contaminant of concern in Leavenworth Creek but is shown as an example of diel cycling in anionic constituents. More importantly, zinc, which is of interest for this study, showed maximum concentrations during nighttime and minimum concentrations midday for August 29-30 at sites T2 and T3. Diel zinc concentrations varied from 26 to 33 percent at the two stream sites.

The profile of bromide-calculated stream discharge and velocity-meter measurements indicates increasing stream discharge over the study reach from approximately 1.8 to 4.3 cubic feet per second. The largest single increase occurred from approximately 1,000 to 1,250 meters (m) downstream from the injection site, where the Wilcox Tunnel inflow joins the stream. Stream discharge more gradually increased from approximately 1,250 to $2,000 \mathrm{~m}$ in the reach containing the dispersed tailings deposits. There is possible stream discharge loss in the most downstream reaches of the study area. For the loading analysis, the stream discharge calculated from bromide dilution was used at all stream sites and represents all water flowing in multiple channels and some perhaps lost to shallow groundwater flow at the end of the study reach.

Zinc and copper concentrations in filtered ( 0.45 micrometer) synoptic samples increased moving downstream, with zinc concentration increases being more pronounced than those of copper. Zinc and copper concentrations increased at approximately $1,250 \mathrm{~m}$, downstream from the Wilcox Tunnel and Waldorf seep inflows, and again just downstream from the left-bank inflow, LC1843-L (at 1,843 m), these inflows generally showed the greatest concentrations of filtered zinc and copper along the study reach. Concentrations of filtered zinc are generally greater in left-bank than right-bank inflow samples along the study reach. Copper left-bank inflow concentrations are consistently greater than right-bank inflow concentrations starting at the Wilcox Tunnel and Waldorf seep inflows and moving downstream.

Mass-load profiles of total copper, lead, manganese, and zinc and percent of cumulative mass load (proportional load) showed that the inflows from the Wilcox Tunnel and Waldorf seep area are important loading sources. Inflows from the Wilcox Tunnel and Waldorf seep area were the greatest source of zinc load to the stream (about 45 percent), and a left-bank inflow in the dispersed tailings area was the greatest source of lead (about 45 percent) and manganese (about 25 percent) loads to the stream, and a secondary source for zinc (about 40 percent). Copper load was almost equally divided (about 35 percent) between these two sources. In addition, in the stream reach from approximately 800 to 1,200 m, copper, lead, manganese, and zinc loads gradually increase, likely from diffuse groundwater loading and left-bank inflows in this zone. Zinc shows this pattern to a lesser degree than the other metals near the downstream end of this reach (1,000-1,200 m). Similarly, in the reach containing dispersed tailings on the left bank, from approximately 1,300-1,800 m, copper and lead, and to a lesser extent manganese loads gradually increase, likely because of diffuse loading from the dispersed tailings. The cause of one large lead source near 2,000 m is not known.

The absolute value of loads reported herein are minimum estimates because the instream synoptic samples were collected at 1200 hours near when minimum concentrations for positively charged elements occurred in the stream. In addition, stream discharge was also at a minimum at that time. Based on the diel patterns measured for zinc during the synoptic sampling, maximum daily zinc loads would be expected to be as much as 33 percent greater than those measured at 1200 hours on August 30, 2012.

Together, the loading and visual evidence indicate that transmountain diversion of water to Leavenworth Creek from Peru Creek negatively affects the water quality in Leavenworth Creek. An additional evaluation of the effect of imported compared to native Vidler Tunnel water would be to compare loads at the upstream and downstream ends of Vidler Tunnel when water imports are active to quantify the amount of load from native flow that occurs during higher flow and what effect mineralization in the Vidler Tunnel has on metal loads. Such a comparison was not included in this study.

\section{References Cited}

14.ers.com, 2019, Front Range-Mt. Edwards: 14ers.com web page, accessed August 20, 2019, at https://www.14ers.com/ 13ers/peak.php?peakkey=470.

Balistrieri, L.S., Nimick, D.A., and Mebane, C.A., 2012, Assessing time-integrated dissolved concentrations and predicting toxicity of metals during diel cycling in streams: Science of the Total Environment, v. 425, p. 155-168, accessed April 28, 2019, at https://doi.org/10.1016/ j.scitotenv.2012.03.008.

Barringer, J.L., and Johnsson, P.A., 1989, Theoretical considerations and a simple method for measuring alkalinity and acidity in low pH waters by Gran titration: U.S. Geological Survey Water-Resources Investigations Report 89-4029, 36 p., accessed April 28, 2019, at https://pubs.er.usgs.gov/ publication/wri894029. 
Brick, C.M., and Moore, J.N., 1996, Diel variation of trace metals in the upper Clark Fork River, Montana: Environmental Science \& Technology, v. 30, no. 6, p. 1953-1960, accessed April 28, 2019, at https://doi.org/ 10.1021/es9506465.

Brinton, T.I., Antweiler, R.C., and Taylor, H.E., 1996, Method for the determination of dissolved chloride, nitrate, and sulfate in natural water using ion chromatography: U.S. Geological Survey Open-File Report 95-426A, 16 p., accessed April 28, 2019, at https://pubs.er.usgs.gov/ publication/ofr95426A.

Campbell, K.M., Gallegos, T.J., and Landa, E.R., 2015, Biogeochemical aspects of uranium mineralization, mining, milling, and remediation: Applied Geochemistry, v. 57, p. 206-235, accessed October 8, 2021, at https://doi.org/ 10.1016/j.apgeochem.2014.07.022.

City of Golden, 2019, Water supply, City of Golden web page, accessed March 5, 2019, at https://www.cityofgolden.net/ government/departments-divisions/water/water-supply/.

Colorado Division of Water Resources, 2019, Colorado's surface water conditions-Vidler tunnel near Argentine pass (VIDTUNCO): Colorado Division of Water Resources database, accessed October 8, 2021, at https://dwr.state.co.us/ Tools/Stations/VIDTUNCO?params=DISCHRG .

Colorado State University, 2019, Access Colorado data, Cabin Creek Station: Fort Collins, Colo., Colorado State University database, Colorado Climate Center, accessed February 14, 2019, at http://climate.colostate.edu/ data_access.html.

Doeskin, N.J., Pielke, R.A., Sr., and Bliss, O.A.P., 2003, Climate of Colorado-Climatography of the United States, No. 60: Fort Collins, Colo., Colorado State University, Colorado Climate Center, accessed February 14, 2019, at https://climate.colostate.edu/climate_long.html.

Farrar, J.W., 1998, Results of the U.S. Geological Survey's analytical evaluation program for standard reference samples- $-\mathrm{T}-151$ (trace constituents), M-144 (major constituents), $\mathrm{N}-55$ (nutrient constituents), $\mathrm{N}-56$ (nutrient constituents), P-29 (low ionic strength constituents), GWT-2 (ground-water trace constituents), GWM-2 (ground-water major constituents), AMW-4 (acid mine water constituents), and Hg-25 (mercury) distributed in September 1997: U.S. Geological Survey Open-File Report 98-52, 191 p., accessed April 25, 2019, at https://doi.org/10.3133/ofr9852.

Fey, D.L., and Wirt, L., 2007, Mining-impacted sources of metal loading to an alpine stream based on a tracer-injection study, Clear Creek County, Colorado: Geological Society of America Reviews in Engineering Geology, v. XVII, p. 85-103.
Fuller, C.C., and Davis, J.A., 1989, Influence of coupling of sorption and photosynthetic processes on trace element cycles in natural waters: Nature, v. 340, no. 6228, p. 52-54, accessed April 28, 2019, at https://doi.org/10.1038/340052a0.

Gammons, C.H., Nimick, D.A., and Parker, S.R., 2015, Diel cycling of trace elements in streams draining mineralized areas-A review: Applied Geochemistry, v. 57, p. 35-44, accessed September 5, 2019, at https://doi.org/10.1016/ j.apgeochem.2014.05.008.

Gibs, J., Wilde, F.D., and Heckathorn, H.A., 2012, Use of multiparameter instruments for routine field measurements: U.S. Geological Survey Techniques of Water-Resources Investigations, book 9, chap. A6, section 6.8, accessed August 5, 2020, at https://doi.org/10.3133/twri09A6.8.

Hageman, P.L., 2004, Use of short-term (5-minute) and long-term (18-hour) leaching tests to characterize, fingerprint, and rank mine-waste material from historical mines in the Deer Creek, Snake River, and Clear Creek watersheds in and around the Montezuma mining district, Colorado: U.S. Geological Survey Scientific Investigations Report 2004-5104, 37 p., accessed April 28, 2019, at https://pubs.usgs.gov/sir/2004/5104/.

Hedge, C.E., 1969, A petrographic and geochronologic study of migmatites and pegmatites in the central Front Range: Golden, Colo., Colorado School of Mines, Ph.D. dissertation, $158 \mathrm{p}$.

Jarvis, A.P., Davis, J.E., Orme, P.H.A., Potter, H.A.B., and Gandy, C.J., 2019, Predicting the benefits of mine water treatment under varying hydrological conditions using a synoptic mass balance approach: Environmental Science \& Technology, v. 53, no. 2, p. 702-709, accessed April 28, 2019, at https://doi.org/10.1021/acs.est.8b06047.

Jensen, E.N., 1998, Landscapes of the mined-An environmental history of mining in the Clear Creek watershed, Clear Creek County, Colorado, 1859-1997: Missoula, Mont., University of Montana, M.A. thesis, 299 p.

Kellogg, K.S., Shroba, R.R., Bryant, B., and Premo, W.R., 2008, Geologic map of the Denver West 30' x 60' quadrangle, north-central Colorado: U.S. Geological Survey Scientific Investigations Map 3000, scale 1:100,000, 48-p. pamphlet, accessed February 14, 2019, at https://pubs.usgs.gov/sim/3000/.

Kilpatrick, F.A., and Cobb, E.D., 1985, Measurement of discharge using tracers: U.S. Geological Survey Techniques of Water-Resources Investigations, book 3, chap. A16, 52 p. [Also available at https://doi.org/10.3133/twri03A16.] 
Kimball, B.A., Nimick, D.A., Gerner, L.J., and Runkel, R.L., 1999, Quantification of metal loading in Fisher Creek by tracer injection and synoptic sampling, Park County, Montana, August 1997: U.S. Geological Survey Water-Resources Investigations Report 99-4119, 40 p., accessed April 28, 2019, at https://pubs.er.usgs.gov/publication/wri994119.

Kimball, B.A., and Runkel, R.L., 2009, Spatially detained quantification of metal loading for decision making - Metal mass loading to American Fork and Mary Ellen Gulch, Utah: Mine Water and the Environment, v. 28, no. 4, p. 274-290, accessed April 27, 2019, at https://doi.org/ 10.1007/s10230-009-0085-5.

Kimball, B.A., Runkel, R.L., and Walton-Day, K., 2010, An approach to quantify sources, seasonal change, and biogeochemical processes affecting metal loading in streams-Facilitating decisions for remediation of mine drainage: Applied Geochemistry, v. 25, no. 5, p. 728-740, accessed April 27, 2019, at https://doi.org/ 10.1016/j.apgeochem.2010.02.005.

Kimball, B.A., Runkel, R.L., Walton-Day, K., and Bencala, K.E., 2002, Assessment of metal loads in watersheds affected by acid mine drainage by using tracer injection and synoptic sampling-Cement Creek, Colorado, USA: Applied Geochemistry, v. 17, no. 9, p. 1183-1207, accessed October 8, 2021, at http://dx.doi.org/ 10.1016/S0883-2927(02)00017-3.

Kimball, B.A., Walton-Day, K., and Runkel, R.L., 2007, Quantification of metal loading by tracer injection and synoptic sampling, 1996-2000, chap. E9 of Church, S.E., von Guerard, P., and Finger, S.E., eds., Integrated investigations of environmental effects of historical mining in the Animas River watershed, San Juan County, Colorado: U.S. Geological Survey Professional Paper 1651, p. 423-495, accessed April 28, 2019, at https://pubs.usgs.gov/pp/1651/ downloads/Vol1_combinedChapters/vol1_chapE9.pdf.

Lamothe, P.J., Meier, A.L., and Wilson, S.A., 2002, The determination of forty-four elements in aqueous samples by inductively coupled plasma-mass spectrometry, chap. $\mathrm{H}$ of Taggart, J.E., Jr., ed., Analytical methods for chemical analysis of geologic and other materials, U.S. Geological Survey: U.S. Geological Survey Open-File Report 02-223-H, 11 p., accessed September 5, 2019, at https://pubs.usgs.gov/of/ 2002/ofr-02-0223/H21\&23OFR99-151_M.pdf.

Long, H.K., and Farrar, J.W., 1994, Report on the U.S. Geological Survey's evaluation program for standard reference samples distributed in October 1993-T-127 (trace constituents), $\mathrm{M}-128$ (major constituents), $\mathrm{N}-40$ (nutrients), N-41 (nutrients), P-21 (low ionic strength), $\mathrm{Hg}-17$ (mercury), AMW-3 (acid mine water), and WW-1 (whole water): U.S. Geological Survey Open-File Report 94-42, 177 p., accessed April 9, 2019, at https://doi.org/ 10.3133/ofr9442.
Long, H.K., and Farrar, J.W., 1995, Report on the U.S. Geological Survey's evaluation program for standard reference samples distributed in October 1994-T-131 (trace constituents), T-133, (trace constituents), M-132 (major constituents), N-43 (nutrients), N-44 (nutrients), P-23 (low ionic strength) and Hg-19 (mercury): U.S. Geological Survey Open-File Report 95-117, 139 p., accessed April 9, 2019, at https://doi.org/10.3133/ofr95117.

Lovering, T.S., 1935, Geology and ore deposits of the Montezuma quadrangle, Colorado: U.S. Geological Survey Professional Paper 178, 119 p., accessed April 28, 2019, at https://pubs.er.usgs.gov/publication/pp178.

Lovering, T.S., and Goddard, E.N., 1950, Geology and ore deposits of the Front Range, Colorado: U.S. Geological Survey Professional Paper 223, 319 p., 30 pls., accessed April 28, 2019, at https://pubs.er.usgs.gov/ publication/pp223.

Malem, F., 2006, Hydrogeochemistry of hard-rock mine waste in a semi-arid climate: Golden, Colo., Colorado School of Mines, Ph.D. dissertation T-6163, 333 p.

Mayes, W.M., Gozzard, E., Potter, H.A.B., and Jarvis, A.P., 2008, Quantifying the importance of diffuse minewater pollution in a historically heavily coal mined catchment: Environmental Pollution, v. 151, no. 1, p. 165-175, accessed April 28, 2019, at https://doi.org/10.1016/ j.envpol.2007.02.008.

McDougal, R.R., and Wirt, L., 2007, Characterizing infiltration through a mine-waste dump using electrical geophysical and tracer-injection methods, Clear Creek County, Colorado, in DeGraff, J.V., ed., Understanding and responding to hazardous substances at mine sites in the western United States: Geological Society of America Reviews in Engineering Geology, v. XVII, p. 9-24.

Nimick, D.A., and Cleasby, T.E., 2001, Quantification of metal loads by tracer injection and synoptic sampling in Daisy Creek and the Stillwater River, Park County, Montana, August 1999: U.S. Geological Survey Water-Resources Investigations Report 2000-4261, 51 p., accessed April 28, 2019, at https://pubs.er.usgs.gov/publication/wri004261.

Nimick, D.A., Gammons, C.H., and Parker, S.R., 2011, Diel biogeochemical processes and their effect on the aqueous chemistry of streams-A review: Chemical Geology, v. 283, no. 1-2, p. 3-17, accessed September 5, 2019, at https://doi.org/10.1016/j.chemgeo.2010.08.017.

Parker, S.R., Gammons, C.H., Poulson, S.R., and DeGrandpre, M.D., 2007, Diel variations in stream chemistry and isotopic composition of dissolved inorganic carbon, upper Clark Fork River, Montana, USA: Applied Geochemistry, v. 22, no. 7, p. 1329-1343, accessed April 27, 2019, at https://doi.org/10.1016/j.apgeochem.2007.02.007. 
Pearson, R., McCaig, R., and Prince, N., 1997, Preliminary assessment—Waldorf Mine/Santiago Mine, Clear Creek County, Colorado: Denver, Colo., U.S.D.A Forest Service, prepared by U.S. Bureau of Reclamation, Technical Service Center, $30 \mathrm{p}$.

Runkel, R.L., Walton-Day, K., Kimball, B.A., Verplanck, P.L., and Nimick, D.A., 2013, Estimating instream constituent loads using replicate synoptic sampling, Peru Creek, Colorado: Journal of Hydrology, v. 489, p. 26-41, accessed, April 27, 2019, at https://doi.org/10.1016/ j.jhydrol.2013.02.031.

Story, C., 2009, Surface and hyporheic zone water toxicity to benthic macroinvertebrates in a first-order alpine stream, Clear Creek County, Colorado: Golden, Colo., Colorado School of Mines, M.S. thesis, $147 \mathrm{p}$.

Sunrise Sunset, 2019a, June 2012-Georgetown, ColoradoSunrise and sunset calendar: Sunrise Sunset web page, accessed April 11, 2019, at https://sunrise-sunset.org/us/ georgetown-co/2012/6.

Sunrise Sunset, 2019b, August 2012—Georgetown, Colorado-Sunrise and sunset calendar: Sunrise Sunset web page, accessed April 11, 2019, at https://sunrise-sunset.org/ us/georgetown-co/2012/8.

Turnipseed, D.P., and Sauer, V.B., 2010, Discharge measurements at gaging stations: U.S. Geological Survey Techniques and Methods book 3, chap. A8, 87 p., accessed April 28, 2019, at https://doi.org/10.3133/tm3A8.

U.S. Environmental Protection Agency, 2012, Waterbody quality assessment report—2012 waterbody report for Leavenworth Creek: U.S. Environmental Protection Agency web page, accessed August 18, 2019, at https://ofmpub.epa.gov/ waters10/attains_waterbody.control?p_list_id=COSPCL03B_ 0700\&p_cycle $=\& p \_r e p o r t \_t y p e=\#$ causes .

U.S. Forest Service, 2013a, Leavenworth watershed abandoned mine sites-Data summary report: U.S. Forest Service, prepared by URS Corporation, project no. 22242465, 228 p.

U.S. Forest Service, 2013b, Leavenworth watershed abandoned mine sites-Evaluation of existing data and data gap analysis report: U.S. Forest Service, prepared by URS Corporation, project no. 22242465, 284 p.

U.S. Geological Survey, [USGS], 2005, Results for the fall 2005 inter-laboratory comparison study: U.S. Geological Survey, Office of Water Quality, Branch of Quality Systems, Standard Reference Sample Project, accessed September 5, 2019, at https://bqs.usgs.gov/srs_study/ reports/round_details.php?fy=2005\&season=2.
U.S. Geological Survey, [USGS], 2006, Results for the spring 2006 inter-laboratory comparison study: U.S. Geological Survey, Office of Water Quality, Branch of Quality Systems, Standard Reference Sample Project, accessed September 5, 2019, at https://bqs.usgs.gov/srs_study/ reports/round_details.php?fy=2006\&season=1.

U.S. Geological Survey, [USGS], 2010, Results for the spring 2010 inter-laboratory comparison study: U.S. Geological Survey, Office of Water Quality, Branch of Quality Systems, Standard Reference Sample Project, accessed September 5, 2019, at https://bqs.usgs.gov/srs_study/ reports/round_details.php?fy=2010\&season=1.

U.S. Geological Survey, [USGS], 2011, Results for the fall 2011 inter-laboratory comparison study: U.S. Geological Survey, Office of Water Quality, Branch of Quality Systems, Standard Reference Sample Project, accessed September 5, 2019, at https://bqs.usgs.gov/srs_study/ reports/round_details.php?fy=2011\&season=2.

U.S. Geological Survey, [USGS], 2012, Results for the spring 2012 inter-laboratory comparison study: U.S. Geological Survey, Office of Water Quality, Branch of Quality Systems, Standard Reference Sample Project, accessed September 5, 2019, at https://bqs.usgs.gov/srs_study/ reports/round_details.php?fy=2012\&season=1.

U.S. Geological Survey, [USGS], 2019a, Site map for Colorado-USGS 06714800 Leavenworth Creek at mouth near Georgetown, Colorado: U.S. Geological Survey National Water Information System database, accessed February 15, 2019, at https://waterdata.usgs.gov/co/nwis/ nwismap/?site_no=06714800\&agency_cd=USGS.

U.S. Geological Survey, [USGS], 2019b, USGS water data for the Nation-USGS 06714800 Leavenworth Creek at mouth near Georgetown, Colorado: U.S. Geological Survey National Water Information System database, accessed March 5, 2019, at https://waterdata.usgs.gov/co/nwis/ dv?cb_00010 $=$ on\&cb_00060 $=$ on\&cb_00095 $=$ on \&cb_ 80154=on\&cb_80155=on\&format $=$ gif_default\&site_no= 06714800\&referred_module=sw\&period=\&begin_date $=$ 2012-03-01\&end_date=2012-12-01.

U.S. Geological Survey, [USGS], 2019c, Inter-laboratory comparison study results, standard reference samples M-178, T-183, T-185, T-201, T-207, and T-209: U.S. Geological Survey, Office of Water Quality, Branch of Quality Systems, Standard Reference Sample Project, accessed August 5, 2020, at https://qsb.usgs.gov/srs_study/reports/index.php.

U.S. Geological Survey, 2019d, USGS water data for the Nation: U.S. Geological Survey National Water Information System database, accessed March 5, 2019, at https://doi.org/ 10.5066/F7P55KJN. 
Walton-Day, K., Paschke, S.S., Runkel, R.L., and Kimball, B.A., 2007, Using the OTIS solute-transport model to evaluate remediation scenarios in Cement Creek and the upper Animas River, chap. E24 of Church, S.E., von Guerard, P., and Finger, S.E., eds., Integrated investigations of environmental effects of historical mining in the Animas River watershed, San Juan County, Colorado: U.S. Geological Survey Professional Paper 1651, p. 979-1028, accessed April 27, 2019, at https://pubs.usgs.gov/pp/1651/ downloads/Vol2_combinedChapters/vol2_chapE24.pdf.

Walton-Day, K., Runkel, R.L., and Kimball, B.A., 2012, Using spatially detailed water-quality data and solutetransport modeling to support total maximum daily load development: Journal of the American Water Resources Association, v. 48, no. 5, p. 949-969, accessed April 28, 2019, at https://doi.org/10.1111/j.1752-1688.2012.00662.x.

Walton-Day, K., Runkel, R.L., and Kimball, B.A., 2021, Stream discharge, sodium, bromide, and specific conductance data for stream and hyporheic zone samples affected by injection of sodium bromide tracer, Leavenworth Creek, Clear Creek County, Colorado, August 2012: U.S. Geological Survey data release, https://doi.org/10.5066/ P9HGC2V4.

Wanty, R.W., and Winter, T.C., 2000, A simple device for measuring differences in hydraulic head between surface water and shallow ground water: U.S. Geological Survey Fact Sheet 077-00, 2 p., accessed April 9, 2019, at https://pubs.usgs.gov/fs/fs-0077-00/fs-0077-00.pdf.
Western Regional Climate Center, 2016, Cabin Creek, Colorado-Period of record monthly climate summary: Western Regional Climate Center web page, accessed February 14, 2019, at https://wrcc.dri.edu/cgi-bin/ cliMAIN.pl?co1186.

Wilde, F.D., ed., 2004, Cleaning of equipment for water sampling (ver. 2.0, April 2004): U.S. Geological Survey Techniques of Water-Resources Investigations, book 9, chap. A3, accessed August 5, 2020, at https://doi.org/ 10.3133/twri09A3.

Wilde, F.D., ed., 2006, Collection of water samples (ver. 2.0, September 2006): U.S. Geological Survey Techniques of Water-Resources Investigations, book 9, chap. A4, accessed August 5, 2020, at https://doi.org/10.3133/twri09A4.

Wilde, F.D., Radtke, D.B., Gibs, J., and Iwatsubo, R.T., eds., 2002, Processing of water samples (ver. 2.0, April 2002): U.S. Geological Survey Techniques of Water-Resources Investigations, book 9, chap. A5, accessed August 5, 2020, at https://doi.org/10.3133/twri09A5.

Woodworth, M.T., and Connor, B.F., 2003, Results of the U.S. Geological Survey's analytical evaluation program for standard reference samples distributed in March 2003: U.S. Geological Survey Open-File Report 03-261, 109 p., accessed August 5, 2020, at https://qsb.usgs.gov/srs/Report_ Spr03.pdf.

Publishing support provided by:

Denver Publishing Service Center

For more information concerning this publication, contact:

Director, USGS Colorado Water Science Center

Box 25046, Mail Stop 415

Denver, CO 80225

(303) 236-4882

Or visit the Colorado Water Science Center website at:

https://www.usgs.gov/centers/co-water 
